\title{
ANÁLISE DE RISCOS CLIMÁTICOS E ESTRATÉGIAS DE IRRIGAÇÃO PARA MILHO "SAFRINHA" NO PARANÁ, ATRAVÉS DE MODELOS DE SIMULAÇÃO
}

\author{
CÉLIO ORLI CARDOSO \\ Engenheiro Agrônomo
}

Orientador: Prof. Dr. Marcos Vinícius Folegatti

Tese apresentada à Escola Superior de Agricultura "Luiz de Queiroz", Universidade de São Paulo, para obtenção do título de Doutor em Agronomia, Área de Concentração: Irrigação e Drenagem

PIRACICABA

Estado de São Paulo - Brasil

Janeiro - 2001 
Dados Internacionais de Catalogação na Publicação (CIP)

DIVISÃO DE BIBLIOTECA E DOCUMENTAÇÃO - Campus "Luiz de Queiroz"/USP

Cardoso, Célio Orli

Análise de riscos climáticos e estratégias de irrigação para milho "safrinha" no Paraná, através de modelos de simulação / Célio Orli Cardoso. - Piracicaba, 2001.

$114 \mathrm{p}$.

Tese (doutorado) - Escola Superior de Agricultura Luiz de Queiroz, 2001.

Bibliografia.

1. Época de semeadura 2. Irrigação 3. Milho 4. Modelo matemático 5. Safrinha 6. Simulação I. Título

CDD 633.15

Permitida a copia to tal ou parcíal deste documento.deste que citada a fonte $-\mathbf{0}$ autor

Data do dopora junto a CPQ/ESALO

$-26 / 01 / 01$ 
A Deus ... resposta de tudo o que ainda não sabemos...

\title{
Ofereço
}

\author{
A vocês... \\ que hoje já ausentes, \\ mas em espirito sempre presentes, \\ na lembrança, no amor e na saudade... \\ A realização de um de vossos sonhos \\ Dedico a vocês \\ Meus PAIS
}

\section{Ana Neci Antunes Cardoso e Orly Miguel Cardoso}

(In Memoria)

\section{A vocês ...}

Pais por natureza, por opção e amor, não bastaria dizer que não tenho palavras para agradecer por tudo que me proporcionastes e, principalmente, pela grande contribuição para a realização de mais esta etapa. Mas é o que me acontece agora, quando procuro uma forma verbal de exprimir uma emoção impar. Uma emoção que palavras dificilmente traduziriam...

\section{Dedico à vocês}

À Eliane, minha namorada, esposa e companheira... Minha grande "Paixão" 


\section{AGRADECIMENTOS}

A DEUS por suas obras, a natureza e a vida...

Ao professor e colega Dr. Marcos Vinícius Folegatti, pelas oportunas orientaçōes e total apoio, cujos quais permitiram o desenvolvimento deste trabalho;

Ao pesquisador do IAPAR, professor e colega Dr. Rogério Teixeira de Faria, pela idéia inicial do tema e pelas oportunas sugestões e orientações, o que vieram culminar com esta Tese, e pelos conhecimentos transmitidos ao longo da disciplina de simulação e modelagem; e ao IAPAR pela concessão dos dados;

A todos os demais professores da ESALQ em especial aqueles que me tiveram como aluno em suas respectivas disciplinas: José Antônio Frizzone, Tarlei Botrel, Durval Dourado Neto, Fernando Peres, Paulo Libardi, entre outros;

A Escola Superior de Agricultura "Luiz de Queiroz" ESALQ e a Universidade de São Paulo USP pela oportunidade ímpar para a realização do curso de Doutorado; À Coordenadoria de Aperfeiçoamento de Pessoal de Nivel Superior (CAPES) pela pequena e curta bolsa de estudo concedida.

Ao meu primeiro e grande mestre na área de irrigação e hoje amigo de trabalho Prof. Mário Nestor Ullmann pelos ensinamentos iniciais e atuais e pelo nosso convivio no Departamento de Engenharia Rural do CAV/UDESC-Lages.

Ao Colega, desde o tempo de graduação no CAV e agora companheiro de trabalho Olívio José Soccol, pela ajuda e apoio; Beleza! Daqui a pouco é a tua...

Ao Prof. Ms. Davi José Miquelutti pela valiosa ajuda nas análises estatísticas.

Aos Colegas que dividiram uma casa no bairro Nova América em Piracicaba: Reginaldo (Entomologia), Cesar (Solos), Jairo (Entomologia) e Antonini (Horticultura), e ao Tim (Irrigação) que assumiu a minha vaga.

Aos Colegas do curso de doutoramento: Alexandre, Dalcio, Edivânia, Jaqueline, Fátima, Thales, Raquel, Odair, Edson, Fabiano, Paulão Sentelhas, etc, pelo caloroso e saudável convívio, amizade, brincadeiras e trocas de conhecimentos;

A todos os funcionários do Departamento de Engenharia Rural da ESALQ, ao Gilmar, Cezar e Hélio pelo apoio técnico e em especial a Davilmar e a Dona Vera; Aos meus PAIS por tudo que me proporcionaram em vida e mesmo agora... À minha querida Avó Clara Antunes Pessoa (In memoria), com toda certeza, que de uma forma ou de outra tem me ajudado;

À Eliane, por tudo que tens me proporcionado... por ter me esperado... 


\section{SUMÁRIO}

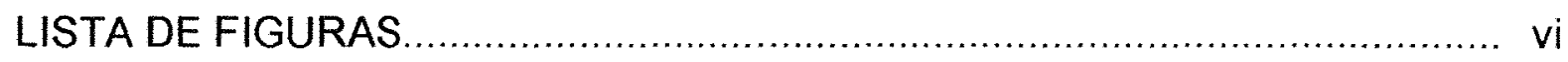

LISTA DE TABELAS E QUADROS ....................................................... viii

RESUMO

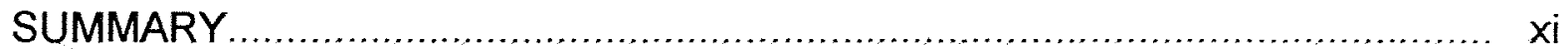

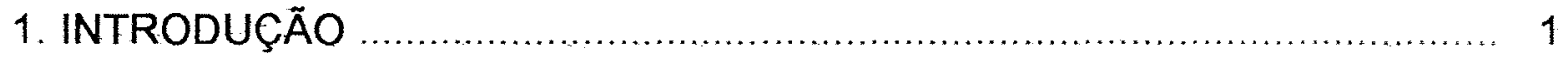

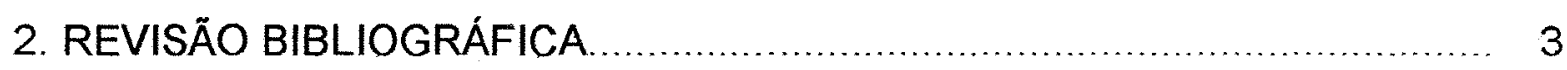

2.1. Milho "Safrinha" ................................................................... 3

2.2. Mercado Interno do Milho ....................................................... 4

2.3. Riscos Associados ao Milho "Safrinha" .......................................... 6

2.4. Épocas de Semeadura........................................................ 7

2.5. Necessidade de Irrigação.......................................................... 9

2.6. Uso de Modelos ................................................................... 10

2.7. Modelo CERES-Maize ........................................................ 12

2.8. Otimização de Estratégias de Irrigação com Simulação .................... 14

2.9. Aplicações de Modelos para a Otimização da Irrigação ..................... 18

2.10. Critérios Estatísticos da Teoria da Decisão.......................................21

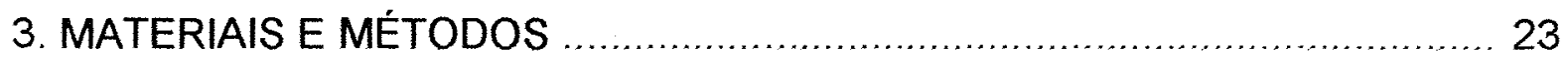

3.1. Descrição do Modelo Ceres-Maize ……………………................. 23

3.1.1. Eventos Fenológicos ............................................................ 25

3.1.2. Produção de Biomassa e Aspectos do Crescimento ..................... 29

3.1.3. Partição de Assimilados ......................................................... 34

3.1.4. Balanço Hídrico do Solo............................................................ 37

3.1.5. Balanço de Nitrogênio ............................................................... 39 
3.2. Dados Requeridos (Inputs) e Saídas (Outputs) do Modelo .......... 40

3.3. Simulaçöes na Subrotina "Seasonal" .................................... 42

3.4. Local de Estudo .............................................................. 44

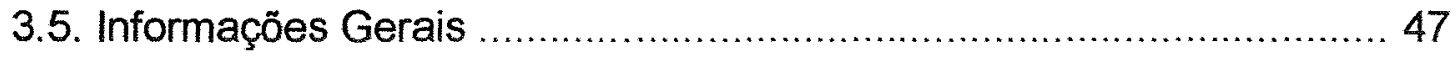

3.6. Dados Relativos ao Manejo...................................................... 47

3.7. Calibração dos Coeficientes Genéticos ....................................... 48

3.8. Considerações Gerais Relativas as Simulações ........................... 49

3.9. Estratégias de Irrigação ........................................................... 50

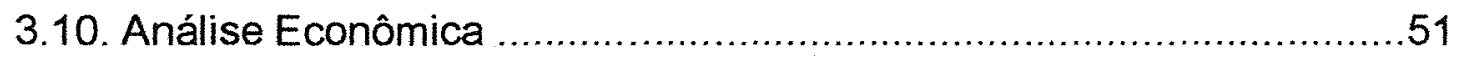

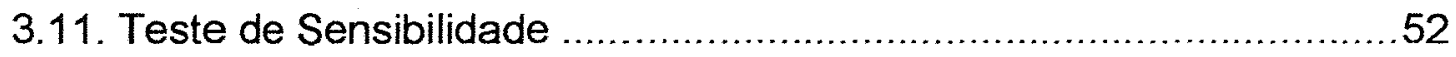

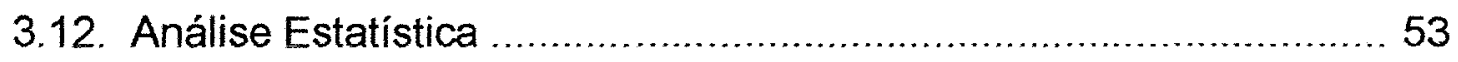

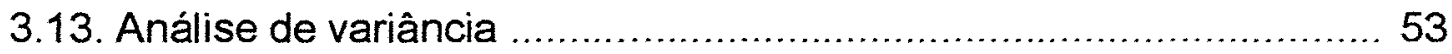

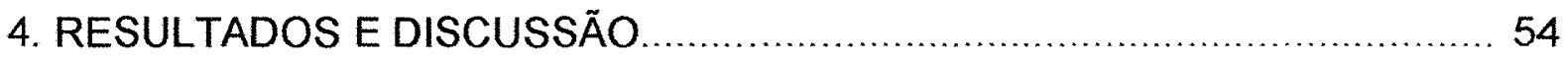

4.1. Simulações para o Cenário de Produção Potencial ......................... 54

4.1.1. Aspectos Fenológicos da Produção Potencial ............................. 54

4.1.2. Rendimentos no Cenário de Produção Potencial ........................ 60

4.2. Simulações para o Cenário sem Irrigação ....................................66 66

4.2.1. Estabelecimento da Cultura e Aspectos Fenológicos ................. 66

4.2.2. Rendimento de Grãos no Cenário sem Irrigação ........................ 72

4.2.3. Analise Econômica para o Cenário sem Irrigação ...................... 76

4.3. Simulações para o Cenário sob Irrigação ..................................... 81

4.3.1. Aspectos Fenológicos no Cenário sob Irrigação ....................... 82

4.3.2. Rendimento de Grãos no Cenário sob Irrigação ......................... 82

4.3.3. Analise Econômica para o Cenário sob Irrigação ......................... 91

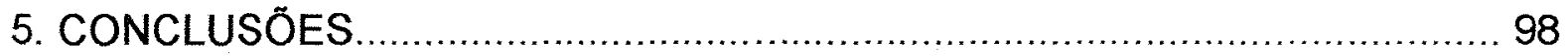

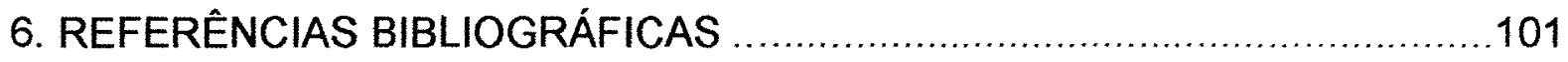




\section{LISTA DE FIGURAS}

2.1. Preços médios por sacas de $60 \mathrm{~kg}$ recebidos pelos produtores de milho no Estado do Paraná de 1993 a 1999. Em real de dezembro de 1999. Deflator: IPG-DI, Fundação Getúlio Vargas. (Nicoleti, 1997; Agrianual, 1999; CONAB, 1999)

3.1. Estrutura e fluxo de informações no modelo CERES-Maize .................. 24

3.2. Esquema simplificado dos passos para a análise seasonal no DSSAT3.5 ...43

3.3. Regionalização do milho para o Paraná e locais das simulações ............... 44

3.4. Ocorrência média de geadas em 10 anos, por mês e local, no Estado do Paraná (Grodzki et al. 1996)

4.1. Durações médias da semeadura à antese e do ciclo do milho "safrinha" em semeaduras no período de janeiro a maio para Londrina e Ponta Grossa, no cenário de produção potencial

4.2. Número de safras com perda total de grãos e ciclo interrompido antecipadamente em 24 anos de simulações para Londrina e Ponta Grossa, no cenário de produção potencial.

4.3. Durações médias do período semeadura à antese do milho "safrinha" devido à variações de radiação solar e temperatura em semeaduras no período de janeiro a maio para Londrina e Ponta Grossa no cenário de produção potencial

4.4. Durações médias do ciclo do milho "safrinha" devido à variações de radiação solar e temperatura em semeaduras no período de janeiro a maio para Londrina e Ponta Grossa, no cenário de produção potencial .. 58

4.5. Números de safras com perda total de grãos para o milho "safrinha" devido à variações de radiação solar e temperatura em semeaduras no período de janeiro a maio para Londrina e Ponta Grossa no cenário de produção potencial

4.6. Rendimentos médios do milho "safrinha" (cultivar XL-520) semeado no período de janeiro a maio para Londrina e Ponta Grossa, no cenário de produção potencial.

4.7. Variações médias do rendimento do milho "safrinha" devido à variações de radiaçāo solar e temperatura em semeaduras no período de janeiro a maio para Londrina e Ponta Grossa, no cenário de produção 
4.8. Probabilidades acumuladas de rendimento médio do milho "safrinha" (cultivar XL-520) semeado no período de janeiro a maio para Londrina e Ponta Grossa, no cenário de produção potencial.

4.9. Rendimentos médios esperados à nível de $10,25,50,75$ e $90 \%$ de probabilidade para o milho "safrinha" semeado no período de janeiro a maio para Londrina e Ponta Grossa, no cenário de produção potencial..... 65

4.10. Frequência de falhas decendiais no estabelecimento do milho "safrinha" (cultivar XL-520) semeado no período de janeiro a maio para Londrina e Ponta Grossa, no cenário sem irrigação

4.11. Probabilidades acumuladas da duração do ciclo do milho "safrinha" (cultivar XL-520 semeado no periodo de janeiro a maio para Londrina e Ponta Grossa, no cenário sem irrigação

4.12. Número de safras com ciclo interrompido e perda total de grãos para o cenário sem irrigação em 24 anos de simulações para Londrina e Ponta Grossa

4.13. Probabilidades acumuladas de datas de colheita do milho "safrinha" semeado no período de janeiro a maio, para Londrina e Ponta Grossa, no cenário sem irrigaçäo

4.14. Rendimentos médios do milho "safrinha" (cultivar XL-520) semeado no período de janeiro a maio para Londrina e Ponta Grossa, nos cenários de produção potencial e sem irrigação

4.15. Probabilidades acumuladas do rendimento médio do milho "safrinha" (cultivar XL-520) semeado no período de janeiro a maio para Londrina e Ponta Grossa, no cenário sem irrigação

4.16. Rendimentos médios esperados à nivel de $10,25,50,75$ e $90 \%$ de probabilidade para o milho "safrinha" semeado no período de janeiro a maio para Londrina e Ponta Grossa, no cenário sem irrigação

4.17. Receita Liquida média do milho "safrinha" (cultivar XL-520), para o cenário sem irrigação, semeado no período de janeiro a maio, em 24 anos de simulações para Londrina e Ponta Grossa.

4.18. Probabilidades acumuladas da receita líquida do milho "safrinha" (cultivar XL-520) semeado no período de janeiro a maio para Londrina e Ponta Grossa, no cenário de chuva atual.

4.19. Rendimentos médios esperados à nivel de $10,25,50,75$ e $90 \%$ de probabilidade para o milho "safrinha" semeado no período de janeiro a maio para Londrina e Ponta Grossa, no cenário sem irrigação

4.20. Receitas líquidas do milho "safrinha" devido à variações nos custos totais de produção e preços do produto, em semeaduras no período de janeiro a maio, em 24 anos de simulações para Londrina e Ponta 
Grossa, no cenário sem irrigação

4.21. Rendimentos médios dos cenários de produção potencial, sem irrigação e sob irrigação para o milho "safrinha" (XL-520) em semeaduras de janeiro a maio para Londrina e Ponta Grossa.

4.22. Rendimentos médios do milho "safrinha" sem irrigação, para os níveis de irrigação e produção potencial em semeaduras de janeiro a maio para Londrina devido a variações nas variáveis meteorológicas

4.23. Variação dos rendimentos médios com o manejo da irrigação a 10,50 e $90 \%$ de AD para o milho "safrinha" semeado no período de janeiro a maio para Londrina devido a variações nas variáveis meteorológicas. 86

4.24. Rendimentos médios do milho "safrinha" sem irrigação, para os níveis de irrigação e produção potencial em semeaduras nos 15 decêndios do período de janeiro a maio para Londrina.

4.25. Funções de probabilidade acumulada de rendimento médio do milho "safrinha" sem irrigação, para os niveis de irrigação e produção potencial em semeaduras de janeiro a maio para Londrina.

4.26. Receita Líquida média do milho "safrinha" (cultivar XL-520) para o cenário sem irrigação e sob irrigação, semeado no periodo de janeiro a maio, em 24 anos de simulações para Londrina.

4.27. Receitas líquidas médias do milho "safrinha" para o cenário sem irrigação e sob irrigação, semeado no período de janeiro a maio em 24 anos de simulações para Londrina.

4.28. Variação da receita Líquida média do milho "safrinha" (cultivar XL-520 para o cenário sem irrigação e sob irrigação, semeado no período de janeiro a maio, em 24 anos de simulações para Londrina em função das variações nos custos e preços do produto.

4.29. Probabilidades acumuladas da receita líquida do milho "safrinha" (cultivar XL-520) semeado no período de janeiro a maio para Londrina, no cenário sem irrigação e sob irrigação 


\section{LISTA DE TABELAS}

3.1. Estágios de Crescimento de culturas no modelo CERES e os órgãos que crescem durante essas fases.

3.2. Dados do perfil do solo, elementos do clima, parâmetros genéticos da cultivar e características do manejo da cultura, necessários para a simulação com o modelo CERES-Maize.

3.3. Dados meteorológicos (médias) para Londrina e Ponta Grossa do período de 1976 a 1999

3.4. Comparação entre dados simulados e experimentos da avaliação estadual de cultivares de milho safrinha em Londrina.

4.1. Valores mínimos, máximos e médios das durações do estádio semeadura à antese e do ciclo total obtidos nas simulações, para Londrina e Ponta Grossa, no cenário de produção potencial 


\title{
ANÁLISE DE RISCOS CLIMÁTICOS E ESTRATÉGIAS DE IRRIGAÇÃO PARA MILHO "SAFRINHA" NO PARANÁ, ATRAVÉS DE MODELOS DE SIMULAÇÃO
}

\author{
Autor: Célio Orli Cardoso \\ Orientador: Prof. Marcos Vinícius Folegatti
}

\section{RESUMO}

O objetivo deste estudo foi obter estratégias otimizadas de irrigação para o cultivo de milho em semeadura tardia ("safrinha"), para uma cultivar de ciclo precoce (XL-520), através da aplicação do modelo de simulação de crescimento pelo processo fisiológico CERES-Maize, em duas localidades do Paraná (Londrina e Ponta Grossa), em diferentes datas de semeadura, bem como fazer uma análise de riscos decorrente de adversidades climáticas associadas a este período de cultivo e às estratégias implementadas.

O modelo CERES-Maize foi desenvolvido pelo Grassland, Soil and Water Research Laboratory, no Texas, (E.U.A) com o objetivo de simular os efeitos das características genéticas, meteorológicas e físico-hídricas dos solos no desenvolvimento e produtividade do milho. Neste estudo, esse modelo será aplicado em simulações de longo período para a obtenção de informações visando estabelecer estratégias adequadas para maximização da renda líquida do milho "safrinha" em duas importantes regiões agrícolas do estado do Paraná.

O milho "safrinha" com semeadura extemporânea, no período de baixa ocorrência de chuvas e temperaturas mais amenas, foi introduzido recentemente (década de 80 ) no sistema de produção agrícola, principalmente no Estado do Paraná, constituindo-se, atualmente, numa das principais alternativas agrícolas para a entresafra das culturas de verão no Centro-Sul do País. Porém, existem, ainda, poucos dados sobre esta modalidade de cultivo, principalmente no tocante a irrigação. Então, busca-se através de simulações de longo período obter informações, ainda não veiculadas na literatura especializada, que venham proporcionar a elevação da produtividade e rentabilidade do milho de "safrinha", neste sistema de produção agrícola. 
Com as simulações verificou-se que as falhas no estabelecimento da cultura aumentaram com o atraso da semeadura, sendo a condição de umidade no solo o fator mais importante. Em alguns anos os ciclos foram afetados drasticamente por temperaturas bastante baixas e, nestes casos, o modelo interrompeu a simulação do ciclo antecipadamente, devido às baixas taxas de crescimento, principalmente em Ponta Grossa. As durações dos estádios e ciclos simulados tenderam a alongar-se quando confrontados com temperaturas mais baixas e o alongamento na duração do ciclo durante o periodo do milho "safrinha" pode atrasar o cultivo da cultura de verão em anos de ocorrência de temperaturas baixas, o que ficou mais evidente em Ponta Grossa, principalmente em semeaduras a partir de março.

A simulações considerando cenários de produção potencial, em que a produtividade é governada somente devido ao clima, e sob o cenário de produção sob restrição hídrica e de nitrogênio, mostraram maiores valores para Londrina (médias de $8100 \mathrm{~kg} \cdot \mathrm{ha}^{-1}$ e $5305 \mathrm{~kg} \cdot \mathrm{ha}^{-1}$, respectivamente) do que em Ponta Grossa (médias de $4075 \mathrm{~kg} \cdot \mathrm{ha}^{-1}$ e $3725 \mathrm{~kg} \mathrm{ha}^{-1}$ ), devido a diferenças nos solos e principalmente nos elementos do clima.

Em Ponta Grossa a exploração desta cultivar, além do mês de janeiro, com o nivel de manjo estabelecido neste estudo, não seria viável mesmo para as semeaduras com a receita líquida positiva, devido ao alto risco de frustrações de safras associadas às mesmas, decorrentes das condições térmicas.

A irrigação em Londrina constituiu-se em uma alternativa viável pois elevou notoriamente os niveis de rendimento em todas as épocas de semeadura, variando em média entre 6000 a $8000 \mathrm{~kg} \mathrm{ha}^{-1}$, e reduziu os riscos de estabelecimento e frustração de safra para esta cultivar. Em todos os niveis a irrigação resultou em rendimentos mais estáveis ao longo de todo o periodo de análise, apresentando dominância de $1^{\circ}$ e $2^{\circ}$ grau em relação a condição sem irrigação, exceto no $1^{\circ}$ decêndio de janeiro.

O modelo CERES-maize mostrou-se sensivel quanto as respostas às variações dos principais elementos climáticos sobre as simulações dos principais processos de crescimento e desenvolvimento do milho "safrinha". 


\title{
CLIMATIC RISKS AND STRATEGIES OF IRRIGATION ANALISYS FOR CORN OUT OF SEASON IN PARANÁ, THROUGH MODELS OF SIMULATION
}

\author{
Auhtor: Célio Orli Cardoso \\ Adviser: Prof. Marcos Vinícius Folegatti
}

\section{SUMMARY}

The objective of this study was to obtain optimized strategies of irrigation for the corn cultivation in late planting (out of season), for an early cycle cultivar ( $\mathrm{XL}$ 520 ), through the application of the model of growth simulation for the physiologic process CERES-Maize. The simulations considered two sites in Paraná state (Londrina and Ponta Grossa) and different planting dates. In addition, risk analyses for climatic adversities associated to each cultivation period and different irrigation management strategies were performed.

The CERES-Maize model was developed by Grassland, Soil and Water Research Laboratory, in Texas, (E.U.A) with the objective of simulating the effects of the characteristics genetic, meteorological and physical-water of the soils in the development and productivity of the corn. In this study, this model is applied over long term simulation to obtain information for management of appropriate strategies for the accompaniment of the corn out of season, through simulations of long period.

The corn out of season with late planting, in the period of low occurrence of rains and low temperatures, was recently introduced (during the 80 's), mostly in the State of Paraná. At the moment, it constitutes on the major agricultural alternative for rotation with summer crops in the Center-south of the Country. Since it is a new crop system, there exist few information on appropriate management practices, mainly concerning irrigation. This information can be assessed by simulations of long period, in an attempt to help farmers to increase crop productivity and profitability during the 'safrinha' period.

The results of the simulations showed that risks for crop establishment increases with as planting is delayed, mostly due limited soil water. In some years, the cycles were drastically affected for lower temperatures and, in those cases, the 
model interrupted the cycle in advance, due to negligible growth rates, mainly in Ponta Grossa.

The durations of the phases and simulated cycles tended to be longer under low temperature. The longer cropping season during "safrinha" may also planting of summer crops, mostly in Ponta Grossa, for corn planted after March.

The potential and the revenues yields of the scenery of current rain was larger in Londrina (on average of $8100 \mathrm{~kg} \cdot \mathrm{ha}^{-1}$ and $5305 \mathrm{~kg} \cdot \mathrm{ha}^{-1}$, respectively) than in Ponta Grossa (on average of $4075 \mathrm{~kg} \cdot \mathrm{ha}^{-1}$ and $3725 \mathrm{~kg} \cdot \mathrm{ha}^{-1}$ ), due to differences in the soils and mainly in the elements of the climate.

In Ponta Grossa the exploration of this cultivar, besides the month of January, with the level of management established in this study, it would not be even viable for the plantings with the positive net income, due to the high risk of frustrations of crops associated to the same ones, current of the thermal conditions.

The irrigation in Londrina was constituted in a viable alternative because it elevated the yields levels flagrantly in all the plantings times, varying on average among 6000 to $8000 \mathrm{~kg} \cdot \mathrm{ha}^{-1}$, and it reduced the establishment risks and crop frustration for this to cultivate. In all the levels the irrigation resulted in stable yield along the whole analysis period, presenting domination of $1^{\circ}$ and $2^{\circ}$ degree in relation to condition without irrigation, except in the $1^{\circ}$ planting of January.

The model CERES-maize was shown sensitive to the answers of the principal climatic elements variations on the principal growth processes simulations and development of the corn out of season. 


\section{INTRODUÇÃO}

O milho cultivado extemporaneamente, denominado "safrinha" é uma modalidade recente e distinta da safra normal, desenvolvendo-se sob condições ambientais sub-ótimas, caracterizadas principalmente pela menor disponibilidade hídrica e térmica. Por se tratar de uma atividade de alto risco, torna-se imperativo a definição de estratégias que visem um planejamento adequado com menores riscos, através da minimização de custos e otimização de rendimentos para o acompanhamento desta cultura.

No Paraná, o milho "safrinha" caracteriza-se como uma cultura de risco, alternando anos de boa produção e outros de quebra, sendo incerto o nivel de produtividade a ser obtido. Em 1997 as lavouras com milho "safrinha" sofreram com a seca e cerca de 82 mil hectares foram perdidos, dentre os 673,7 mil hectares plantados, com produtividade média ficando abaixo de $1400 \mathrm{~kg}^{-\mathrm{ha}^{-1}}$ (CONAB, 1997), muito além do potencial produtivo desta cultura.

Devido ao alto risco que se encontra diretamente envolvido neste processo, a maioria dos agricultores que cultivam o milho "safrinha" usam ainda medidas tecnológicas de baixo custo, caracterizando sua aversão ao risco, acarretando baixas produtividades. Além disso, existem poucas informações e experiências sobre práticas ideais desta modalidade de cultivo, o que dificulta sua aceitação por parte dos agricultores, que não conseguem enxergar as mesmas vantagens comparativas reconhecidas pelos técnicos. Então, informações adequadas a respeito de cultivares mais adaptados, ajuste de épocas de semeaduras, adubação e irrigação certamente irão contribuir para a obtenção de maiores produtividades e decréscimos de riscos e prejuizos, para 
esta modalidade de cultivo. A obtenção destas informações demanda um dispendioso tempo de ensaios e medições morosas e onerosas no campo, que devem ser repetidas ao longo de vários anos, além da limitada aplicabilidade de seus resultados, que só poderão ser utilizados a longo prazo, constituindo-se, atualmente, num processo inviável e ineficiente, para executar análises de longo período. Neste sentido, os modelos de simulação tornam-se uma ferramenta indispensável para a obtenção de informações desta natureza, a curto prazo e com baixo custo. Com o uso dos modelos de simulação a necessidade de dados e medidas diretas no campo podem ser reduzidas e complementadas com informações meteorológicas facilmente disponíveis, que são usadas nas simulações considerando práticas de manejo específicas necessárias a avaliação da potencialidade de produção da cultura em questão.

Embora os modelos possam ser aplicados amplamente, os maiores benefícios da aplicação deste método são alcançados em condições de sistemas agrícolas não tradicionais, como é o caso do milho "safrinha" no Paraná, que é o escopo desta análise.

Os objetivos deste trabalho são:

- Determinar as probabilidades de riscos climáticos associados às épocas de semeaduras para o milho "safrinha" no Paraná;

- Identificar as principais limitações climáticas para o cultivo do milho "safrinha" no Paraná;

- Identificar estratégias eficientes de manejo da irrigação e determinar seus benefícios econômicos para o milho "safrinha", através de simulação de longo período;

- Analisar a viabilidade da irrigação para o milho "safrinha";

- Demonstrar o uso de modelos de simulação de crescimento de culturas para vincular informações sobre a resposta de culturas à irrigação, com análises econômicas e estimativas de riscos, e permitir uma base de informações integradas para tomada de decisões para o planejamento e manejo da irrigação. 


\section{REVISÃO BIBLIOGRÁFICA}

\subsection{MILHO "SAFRINHA"}

A exploração do milho fora da época normal, denominado de milho "safrinha", teve inicio, na década de 80 , no Oeste do Paraná, e se expandiu para todo o pais, com grande expressão econômica, principalmente para a região Centro-Sul. Segundo Caramori et al. (1999), a área destinada ao cultivo do milho "safrinha" no Paraná vem crescendo, chegando a mais de 700 mil hectares nos últimos anos, destacando-se como uma das principais culturas nesse Estado. No Brasil em 1996, a área de milho "safrinha" alcançou cerca de 1,4 milhão de hectares, que foi semelhante à de 1995 (Garcia, 1997), e em 1997 e 1998 a área de milho "safrinha" no Brasil foi de aproximadamente 2,2 e 2,3 milhões de hectares, respectivamente (Faedo, 1999), o que indica o aumento da sua participação no volume total de milho produzido no país. A produção obtida ao redor de 3,3 milhões de toneladas em 1996 (Garcia, 1997) passou para 4,01 milhões de toneladas em 1997 e 5,5 milhões de toneladas em 1998 (Faedo, 1999), tendendo a se estabilizar, embora neste caso, o resultado seja muito dependente das condições de clima. A produtividade média do milho "safrinha" apresenta-se ainda muito baixa, sendo no Paraná ao redor de $2.200 \mathrm{~kg} \cdot$ ha $^{-1}$ aproximadamente $60 \%$ da safra normal. Em 1998 a produtividade média brasileira passou para $2.400 \mathrm{~kg} \cdot \mathrm{ha}^{-1}$ o que fez do milho "safrinha responsável por $12 \%$ da produção brasileira (Faedo, 1999).

Segundo Arias et al. (1997), os principais fatores que explicam os aumentos sucessivos da área de plantio do milho "safrinha" são a possibilidade 
do uso mais racional dos fatores de produção (terra, máquinas, equipamentos e mão-de-obra) em período ocioso do ano, maiores preços do produto nesta época, menor custo operacional e a falta de outras alternativas mais seguras e rentáveis para época. O milho "safrinha", além de se constituir em uma fonte adicional de renda ao produtor, poderá se tornar uma atividade que permitirá mais estabilidade dos preços do milho dentro do ano agrícola.

Porém, por se tratar de atividade de maior risco, muitos produtores de milho "safrinha", que apresentam aversão ao risco, ainda usam medidas tecnológicas de baixo custo, acarretando baixas produtividades e receitas também baixas.

\subsection{MERCADO INTERNO DO MILHO}

Segundo Nicoletti (1997), em geral, os preços do produto caem substancialmente a partir de março, com o início da safra, e mantém-se baixos até junho/julho. A partir de agosto/setembro, os preços se elevam, atingindo seus níveis mais altos em outubro e novembro. A partir daí, dependendo dos estoques e do início da colheita do milho de cultivares precoces em dezembro e jáneiro, os preços voltam a cair. A Figura 2.1 ilustra a oscilação dos preços do mitho recebidos pelos produtores do Estado do Paraná nos anos de 1993 a 1999.

Observa-se que no ano de 1996, os preços apresentaram um comportamento bastante atípico, devido principalmente, à redução da oferta mundial do grão e da quebra de safra no Rio Grande do Sul e Santa Catarina (Nicoletti, 1997).

Em geral os preços se estabilizam em níveis mais baixos de março a maio, segundo Tsunechiro et al. (1999), tendo em vista o encerramento das vendas da nova safra e o escasseamento dos estoques em poder do produtor, a partir de junho os preços tendem a aumentar, quando se iniciam as entradas no mercado das primeiras colheitas da "safrinha". 


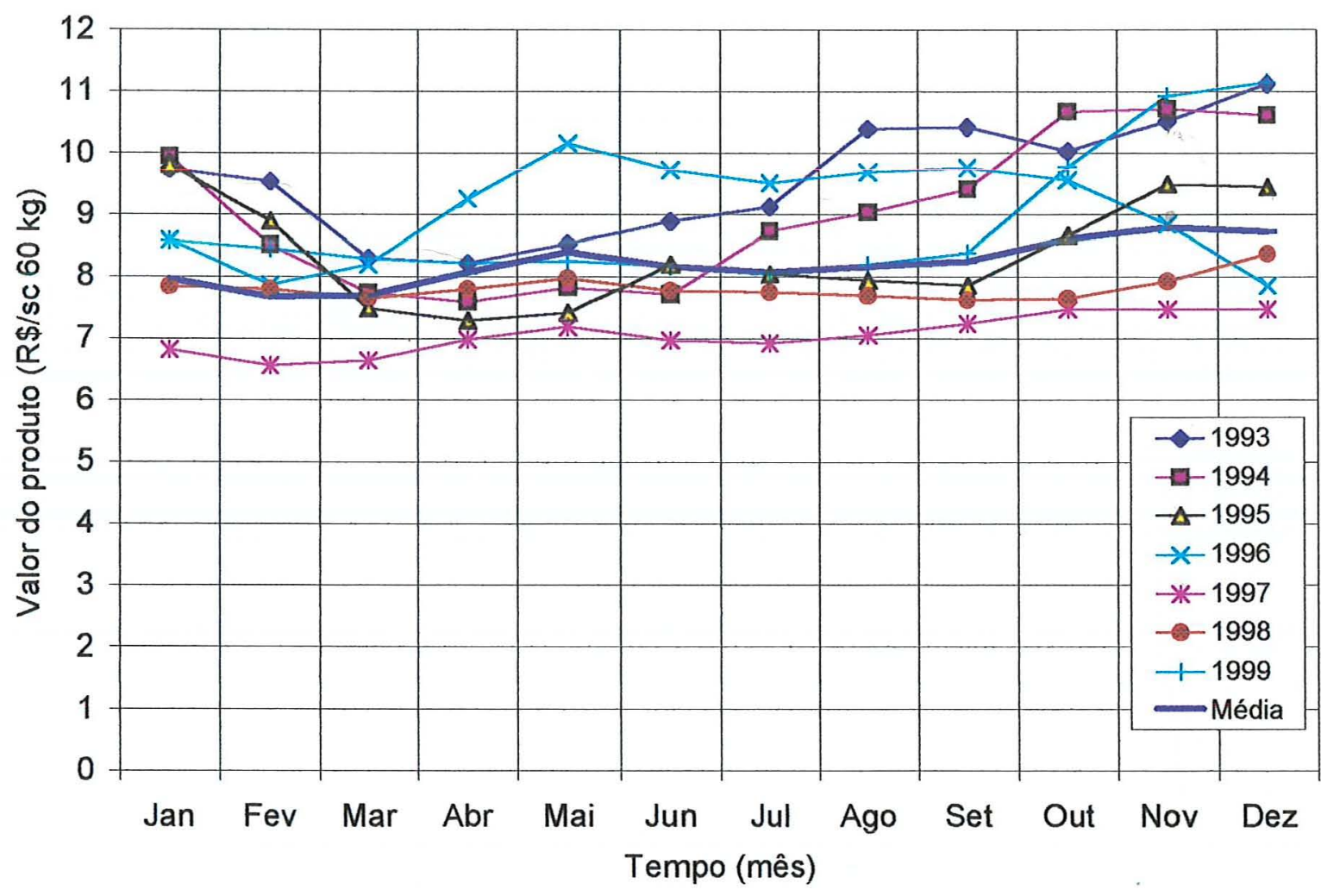

Figura 2.1. Preços médios por sacas de $60 \mathrm{~kg}$ recebidos pelos produtores de milho no Estado do Paraná de 1993 a 1999. Em real de dezembro de 1999. Deflator: IPG-DI, Fundação Getúlio Vargas. (Nicoletti, 1997; AGRIANUAL, 1999; CONAB, 1999)

Segundo Oliveira et al. (1999), mesmo considerando os riscos e a possibilidade de menor rendimento em relação à semeadura do milho no período se safra normal, a prática do cultivo do milho "safrinha" tem sido atrativa, pois a colheita ocorre num período de mercado plenamente comprador, possibilitando ao agricultor obter melhor preço, compensando, em parte, o efeito do menor rendimento. Tsunechiro et al. (1995), ao compararem a rentabilidade estimada de uma produção de grãos, em cultivos de alta tecnologia com rendimento de $4.200 \mathrm{~kg} \mathrm{ha}^{-1}$ obtida no cultivo de milho na safra normal, e $3.300 \mathrm{~kg} \cdot \mathrm{ha}^{-1}$ em cultivo de "safrinha", verificaram que a rentabilidade líquida foi de $R \$ 106,83$ e $R \$ 192,83$ por hectare, respectivamente. 


\subsection{RISCOS ASSOCIADOS AO MILHO "SAFRINHA"}

O estabelecimento da cultura do milho "safrinha" depende, principalmente, da disponibilidade hídrica, além de outros elementos climáticos, tais como a temperatura do ar e do solo, por ocasião e logo após a semeadura, os quais apresentam uma grande variabilidade espacial e temporal, devido a frequente ocorrência de períodos prolongados de escassez de chuvas e temperaturas baixas no período usualmente utilizado para o seu plantio no Paraná.

Em função da época em que é cultivado, segundo Caramori et al. (1999), - milho "safrinha" normalmente está exposto a riscos maiores de perdas por geadas e deficiência hídrica em relação ao cultivo normal, atinge um menor potencial de produtividade e o ciclo da cultura é maior.

Segundo Duarte et al. (1995), em geral, o fator térmico é a principal limitação para o desenvolvimento do milho "safrinha", porém, em algumas regiões a deficiência hídrica pode ser mais limitante. A temperatura tem uma grande influencia na duração do ciclo do milho, podendo retardá-lo ou acelerá10. Hartwig (1975) afirmou que variações anuais no florescimento e maturação de uma cultivar semeada numa mesma data são devidas principalmente, às diferenças de temperatura ocorridas na estação de crescimento. Além disso, uma mesma cultivar pode sofrer alterações em seu ciclo devido a época de semeadura adotada. Assim, pode-se esperar um alongamento na duração do ciclo do milho "safrinha", quando submetido à temperaturas baixas ao longo de seu período vegetativo, o que poderá retardar a liberação da área para o plantio da cultura de verão.

Em resumo, segundo Sartori (1997), algumas condições ideais para o desenvolvimento do milho são: na semeadura o solo deverá apresentar-se com temperatura superior a $10^{\circ} \mathrm{C}$ e a umidade próximo à capacidade de campo; durante o crescimento e desenvolvimento das plantas a temperatura do ar deverá ser próximo de $25^{\circ} \mathrm{C}$ e encontrar-se associada à presença de água disponível no solo; temperaturas e luminosidade favoráveis, grande disponibilidade de 
água no solo e elevada umidade relativa do ar são requisitos básicos durante a floração e enchimento dos grãos. Segundo Miranda Filho (1995), geralmente os problemas de temperaturas baixas no milho "safrinha" relacionam-se com o efeito da temperatura sobre o desenvolvimento vegetativo (fecundação e período de enchimento de grãos) e não propriamente com a germinação e o desenvolvimento de plântulas. Como a semeadura do milho "safrinha" ocorre no verão ou inicio do outono, via de regra, a temperatura do solo não é fator limitante para a germinação e desenvolvimento inicial da cultura.

Alguns pesquisadores tem procurado dar suporte aos estudos de viabilidade climática para o milho "safrinha". Gomes (1995) avaliou o risco da cultura do milho "safrinha", considerando os seguintes limites: térmico temperatura mínima do ar em abrigo meteorológico igual a $3^{\circ} \mathrm{C}$; hídrico probabilidade de verânico ou chuva diária inferior a $5 \mathrm{~mm}$.

Frequentemente o periodo de exploração de milho "safrinha" no Paraná caracteriza-se por peculiaridades próprias, ou seja, por apresentar uma redução gradativa da precipitação pluvial, temperaturas mais baixas e menor luminosidade e assim uma maior probabilidade de ocorrência de geadas, o que podem acarretar uma série de alterações no comportamento das cultivares, em termos de potencial produtivo e comprimento do ciclo, além de outras (Mundstock, 1995). Nessas condições, segundo Gomes (1995), o sucesso da safra depende da combinação entre a época de semeadura e o ciclo da cultivar, que possibilite a fuga dos períodos de seca e de geada. Os estudos de risco levam à verificação, para cada região, das combinações com maior probabilidade de sucesso, ou seja, de maior estabilidade de produtividade, sendo este um dos objetivos deste estudo.

\section{4. ÉPOCAS DE SEMEADURA}

Segundo Silva (1999), o plantio do milho "safrinha" é realizada imediata- 
mente após a colheita da cultura de verão, que geralmente é soja, milho ou feijão, com início em meados de fevereiro e se estendendo até 15 de março.

A liberação da área para o plantio do milho "safrinha" depende da colheita da cultura de verão que o antecede, que por sua vez depende das condições climáticas na primavera do ano anterior, periodo em que seu plantio é recomendado. Sendo assim, segundo Sans et al. (1992), o milho "safrinha" somente pode ser implantado a partir da segunda quinzena de fevereiro, porém, com frequência ocorrem atrasos na colheita das culturas de verão, causados pela necessidade de adiamentos da semeadura em anos com deficiência hídrica por ocasião do plantio (Faria \& Caramori, 1996). Segundo Correia et al. (1997), devido ao plantio tardio, uma série de alterações ocorrem no comportamento das cultivares, em termos de potencial produtivo, ciclo, incidência de pragas e doenças, além de outras.

Segundo Caramori (1999), no Paraná em muitos casos, são cometidos excessos em termos de se estender as épocas de plantio, que chega até os meses de março e abril, expondo a cultura a maiores riscos de perdas por geadas.

A produtividade do milho "safrinha" depende de maneira acentuada, da época de semeadura, ocorrendo intenso decréscimo de produtividade e maior risco de perda quanto mais tardio for o plantio devido à geadas e deficiência hídrica (Dias et al., 1997).

O fator térmico geralmente é a principal limitação para o desenvolvimento do milho "safrinha" enquanto em algumas regiões também a deficiência de água no solo. Nesse contexto, deve-se considerar a possibilidade de ocorrência de geadas, embora sua frequência e intensidade sejam minimizadas ao se adotar a época recomendada para semeadura (Duarte, 1997), que varia de janeiro a março. A data de plantio do milho "safrinha" fica então condicionada à colheita da cultura de verão antecessora, e das condições de chuva e consequente umidade do solo no período de semeadura (Dias et al., 1997), o que frequentemente não tem sido problema. 


\subsection{NECESSIDADE DE IRRIGAÇÃO}

A cultura do milho é tida como exigente em água. Apesar disso, ela é uma das mais eficientes no uso da água, isto é, produz um grande acúmulo de matéria seca por unidade de água absorvida. Segundo Sartori (1997), as maiores exigências em umidade para o milho concentra-se nas fases de emergência, florescimento e formação do grão. Todavia, no período compreendido entre quinze dias antes e quinze dias após o aparecimento da inflorescência masculina, a necessidade de um suprimento hídrico satisfatório aliado a temperaturas adequadas tornam tal período extremamente crítico. Daí a razão pela qual a mencionada fase deve ser criteriosamente planejada, com o intuito de coincidir com o período estacional que apresente temperaturas favoráveis de 25 a $30^{\circ} \mathrm{C}$ e chuvas frequêntes (Frattini, 1975).

Em experimentos de campo Brunini (1982) encontrou, através do balanço hídrico, valores de evapotranspiração real entre 300 a $450 \mathrm{~mm}$ por ciclo, dependendo das condições climáticas, observando que cultivares de ciclo curto apresentam menor consumo total de água que aqueles de ciclo normal.

Deve-se ressaltar que a quantidade de água disponivel para a cultura se encontra na dependência da profundidade explorada pelas raízes, da capacidade de armazenamento de água do solo e da densidade radicular da planta, que de maneira geral, pode-se dizer que cerca de $60 \%$ do sistema radicular se concentra na camada superficial de 0 a $30 \mathrm{~cm}$ (Reichardt, 1987). Assim, o manejo racional, do solo e da cultura, reveste-se de suma importância para o aproveitamento eficiente da água no processo produtivo.

Segundo Reichardt (1987), ótimas produtividades de milho variam de 6 a 9 t.ha $^{-1}$. Em condições de chuva natural, a produtividade oscila entre 2 a 4 t. ha ${ }^{-1}$, dependendo do híbrido e das condiçōes solo-clima. Sendo assim, a água constitui-se num recurso agrícola essencial que frequentemente limita o rendimento do milho. A otimização do uso da água pela planta, com a finalidade de maximizar e estabilizar produtividade pelo uso de quantidades limitadas do 
recurso, é fundamental para diminuir os riscos e aumentar lucros econômicos, e ainda minimizar o impacto ambiental.

Enquanto a irrigação conduz a niveis de rendimento altos e estáveis, os benefícios econômicos desta prática tem que ser estabelecidos principalmente para regiões úmidas, devido ao alto custo do equipamento e operação do sistema de irrigação. Isto poderá ser feito comparando os lucros líquidos entre tratamentos com a cultura irrigada e não irrigada. Neste contexto a programação apropriada da irrigação passa a ser um elemento chave para melhorar o manejo da irrigação, o que pode ser eficientemente avaliado através de simulações de longo período através de modelos matemáticos de simulação em computador.

\subsection{USO DE MODELOS}

Devido as limitações práticas dos vários métodos diretos de quantificação da umidade do solo, consumo de água e processos fisiológicos das plantas, se fez necessário o desenvolvimento de uma metodologia mais simples e adequada para operações rotineiras, e com tal acurácia que permita a obtenção de subsídios necessários a um planejamento racional e eficiente para o manejo dos fatores de produção agrícola, visando a minimização dos custos e a maximização dos rendimentos das culturas.

Uma ferramenta já comprovadamente eficaz, com uso criterioso, na solução de problemas constituídos ou representados por um sistema agrícola, são os modelos matemáticos de simulação do crescimento de culturas em computador, que consistem em conjuntos de equações que descrevem os principais processos físicos e fisiológicos envolvidos no sistema solo-plantaatmosfera. Segundo Jame \& Cutforth (1996), um modelo de crescimento de cultura, além de estimar a quantidade de biomassa ou o rendimento final, também fornecem informações dos principais processos envolvidos no crescimento e desenvolvimento da planta. Assim os modelos de simulação de 
culturas destinam-se a simular as interações do genótipo com o ambiente e seu manejo, e predizer o funcionamento de um sistema de produção em resposta aos fatores que o influenciam, tais como o clima e práticas de manejo (Uehara \& Tsuji, 1993).

O uso recente de modelos de simulação do crescimento vegetal para avaliar as decisões de manejo de culturas tem aberto novos caminhos para pesquisa de planejamento e manejo da irrigação e de outras práticas agrícolas.

Uma chave para o sucesso do manejo de culturas está na habilidade de integrar dados de uma gama de situações dentro de uma forma que permita uma proveitosa informação para tomada de decisão. Neste sentido, experimentos de campo tornam-se laboriosos, caros e demorados, pela necessidade de analisar um grande número de anos, devido a variabilidade climática de ano para ano, e consequente necessidade de água, e incerteza dos rendimentos, os modelos de crescimento de culturas são adequados e a melhor opção para muitas análises de decisões para o manejo da irrigação e outras práticas de cultivo.

O uso de modelos de crescimento vegetal para simulações em computadores possibilita uma economia de tempo, trabalho e quantidade de recursos para as tomadas de decisões de manejo no setor agrícola. No entanto, para a obtenção de um modelo eficiente e confiável, é necessário uma estrutura de apoio para a obtenção dos dados necessários, uma equipe interdisciplinar para a concepção dos programas de computador e experimentos de campo para sua calibração, e avaliação.

Atualmente, encontram-se disponiveis na literatura um grande número de modelos para a simulação de crescimento de diversas culturas de importância econômica e cuja a eficiência já fora comprovada em várias situações. Segundo Salvador (1993), a adaptação destes modelos, para uma localidade específica, requer somente um microcomputador e resultados experimentais do comportamento de cultivos em um período limitado, para que se possa calibrar os modelos ao ambiente desejado. Boote et al. (1996), ressalta três niveis de uso dos modelos de simulação de culturas como 
ferramenta potencialmente útil na tomada de decisões em: pesquisas; manejo de cultivos e estratégias de planejamento agrícola.

Dentre os vários modelos disponíveis com diferentes níveis de complexidade, destacam-se os modelos CERES para simulações de crescimento de gramínias, sendo denominado CERES-Maize o que se destina para simulações com a cultura do Milho, o qual usaremos neste estudo.

\subsection{MODELO CERES-MAIZE}

Este modelo "Crop-Environment Resource Synthesis (CERES)-Maize" foi elaborado por uma equipe interdisciplinar do Laboratório de Pesquisa de solos e Águas, no Texas, Estados Unidos (Jones \& Kiniry, 1986), e foi concebido para quantificar os efeitos independentes e interativos do genótipo, clima, atributos do solo e práticas de manejo do cultivo no crescimento e produção de uma cultivar específica. O modelo simula os principais processos fisiológicos do milho, incluindo: fotossíntese; respiração; acumulação e partição de biomassa; fenologia; extensão do crescimento de folhas, caules e raizes; extração de água do solo, evapotranspiração e rendimento de grãos. CERES-Maize é um modelo mecanístico e determinístico para simulação de crescimento e desenvolvimento do milho pelo processo fisiológico, com passo de calculo diário.

O balanço hídrico do solo é efetuado por um sub-modelo segundo Ritchie (1985) assumindo que a extração de água no solo é governado pela evapotranspiração potencial e disponibilidade de água no solo.

Os dados de entrada e saída (input/output) seguem o formato padrão IBSNAT (1990), em arquivos do tipo ASCII. IBSNAT (International Benchmark Sites Network for Agrotechnology Transfer) foi um programa internacional, com sede na Universidade do Hawaí, que foi criado para desenvolver um sistema para a tomada de decisões e transferência de tecnologia agrícolas, cujo projeto deu-se o nome de DSSAT (Decision Support System for Agrotechnology Trans- 
fer). Este sistema consiste de várias bases de dados, modelos de simulação de produção de culturas de interesse econômico, (tais como: milho, trigo, soja, feijão, etc.) e ferramentas de análises biofísicas e econômicas (Baethgen,1995).

A grande importância do sistema DSSAT na tomada de decisão está na sua habilidade para analisar muitas práticas de manejo diferentes, simulando a produção, uso dos recursos e o risco associado ao manejo analisado.

No Brasil, o modelo CERES-MAIZE foi testado por Liu et al. (1989), utilizando dados meteorológicos, de solo e da cultura do milho híbrido DINA 10, coletados no Centro Nacional de Pesquisa de Milho e Sorgo (CNPMS), localizado em Sete Lagoas - MG. Com base nesses dados, foi feita uma comparação entre o rendimento medido e o simulado para um período de cinco anos (19831987). Os parâmetros genéticos da cultura obtidos em 1983 (ano de calibração) foram usados para simular os dados dos próximos quatro anos (1984, 1985, 1986 e 1987). O estudo mostrou que o modelo produziu estimativas úteis de rendimento do milho para um local específico tendo os autores sugerido a aplicação deste modelo para a estimativa de rendimento em outros locais do Brasil.

Posteriormente, Costa (1992) aplicou o CERES-Maize na microrregião de Ribeirão Preto - SP, calibrando os parâmetros para três áreas, usando dados meteorológicos e calendário do cultivo do ano de 1988. Os coeficientes calibrados foram então usados para rodar o modelo no período de 1984 a 1989. A autora verificou que o modelo simulou bem a produtividade em anos normais, mas tendeu a superestimar a safra nos anos em que foram observados períodos persistentemente chuvosos.

Bowen et al. (1993) testaram o modelo CERES-maize utilizando dados de experimentos conduzidos no CPAC-EMBRAPA-DF, Brasil. A rotina de balanço de nitrogênio deste modelo foi avaliada com respeito à simulação da disponibilidade de $\mathrm{N}$ após a incorporação de adubos verdes. $\mathrm{O}$ submodelo simulou realisticamente bem a liberação de $\mathbf{N}$, porém ficou evidenciado a necessidade de realizar outros trabalhos visando determinar a importância da retenção de nitrato no subsolo e como a retenção pode ser descrita no modelo. 
Lima (1995) avaliou o modelo CERES-maize em condições tropicais do Brasil, através da calibração, validação e teste de sensibilidade de alguns parâmetros do modelo. Foram obtidos os coeficientes genéticos de três cultivares de milho, utilizando dados de experimentos conduzidos junto ao Departamento de Agricultura da ESALQ/USP, em Piracicaba, SP, nos anos de 1993 e 1994. Observou-se que as simulações de crescimento, desenvolvimento e rendimento de grãos foram estimados satisfatoriamente pelo modelo CERES-maize.

Soler (2000) utilizou o modelo CERES-maize para identificar características genéticas desejáveis para milho "safrinha" e práticas de manejo sob condições de risco climático para a região de Ribeirão Preto e Mandurí, SP. Observou-se que maiores rendimentos com o uso de irrigação são obtidos com cultivares de ciclo longo e com maior número de grãos por espiga e, na condição de sequeiro, com cultivares de ciclo curto e maior número de grãos por espiga em ambos os locais. Os maiores rendimentos foram obtidas nas primeiras épocas de semeaduras (janeiro), sendo decrescentes a medida que a semeadura foi mais tardia.

\subsection{OTIMIZAÇÃO DE ESTRATÉGIAS DE IRRIGAÇÃO COM SIMULAÇÃO}

Em regiões úmidas e semi-úmidas, nas ultimas décadas, a irrigação complementar tem se tornado um elemento importante e crescente na agricultura. Entretanto, este aumento do uso da água e de energia pela agricultura irrigada coincide com aumentos similares destes recursos por outros setores da economia, o que poderá estabelecer futuros conflitos.

Devido a alta variabilidade espacial e temporal das chuvas, em regiões úmidas e semi-úmidas, a irrigação complementar torna-se necessária para eliminar o risco associado com a variabilidade intersazonal da produtividade. Estas chuvas podem variar consideravelmente de um ano para outro, e mesmo durante um ciclo de crescimento vegetal completo é comum a ocorrência de 
déficits e excessos hídricos em períodos sucessivos, situação frequente no período de cultivo do milho "safrinha", que afetam o rendimento desta cultura. Sendo assim, a decisão quanto a uma estratégia ótima para a irrigação (quando e quanto irrigar) e sua implementação é muito complicada e polêmica devido a incerteza das chuvas. Além disso a irrigação é uma prática de custo relativamente alto, principalmente devido ao alto consumo de energia. Portanto, fatores como a variabilidade climática, a complexidade natural da resposta das culturas à irrigação, o acréscimo dos custos e a flutuação das condições econômicas muito contribui para um nível de risco inaceitável associado com os benefícios da irrigação complementar (Bogges et al., 1988).

Isso leva a necessidade de reexaminar as práticas de planejamento e manejo da irrigação, tanto quanto ao número de aplicações como também as quantidades aplicadas, bem como quanto ao critério de dimensionamento dos sistemas, que geralmente, baseia-se na maximização do rendimento físico das culturas. Neste contexto, a utilização eficiente e econômica da água está se tornando cada vez mais importante face à escassez de recursos hídricos viáveis e à elevação do custo da energia, o que torna cada vez mais imperativo a utilização de uma metodologia apropriada na quantificação das necessidades hidricas das culturas, visando a obtenção de estratégias otimizadas. Porém, a complexidade e o dinamismo do sistema água-solo-planta-atmosfera tem tornado difícil o trabalho de especialistas ligados ao planejamento e alocação de recursos hídricos na obtenção de informações úteis a seus propósitos.

Segundo Algozin et al. (1988), as pesquisas que envolvem a análise de estratégias de irrigação para o manejo de culturas podem ser feitas a partir de dados experimentais de campo ou através de simulações de longo período, com a utilização de modelos matemáticos.

O manejo das culturas tem como base a habilidade para tomar decisões. Boas decisões requerem boas informações (Bogges et al., 1988). A arte está em encontrar um modo sistemático de integrar dados dentro de um formato que possibilita o uso da informação para tomar decisões. São necessárias 
informações dos efeitos físicos, biológicos, econômicos e dos riscos de uma ação particular. A maioria das decisões de manejo de culturas envolvem numerosos conjuntos de medidas físicas do solo à condições econômicas globais. O processo de decisão é muito complicado pela grande incerteza que circunda muitos de seus componentes chaves. Clima, doenças, preços, mercado exportador, e programas do governo são relativamente muito voláteis. Esta complexidade, associada aos riscos ligados às decisões devido ao ambiente junto com as pressões financeiras que revestem a agricultura evidenciam e valorizam a busca de um manejo otimizado (Swaney et al. 1983).

Nesse contexto, alguns critérios para análise das decisões devem ser seguidos. Um dos critérios baseia-se no máximo rendimento físico, em função da resposta da cultura em relação às variações da água do solo e à frequência e quantidade de irrigação. Um critério mais coerente, baseia-se no lucro máximo, que é definido como o valor total da produção menos os custos, ou seja na maximização da receita e minimização dos custos. Um outro critério, ainda, baseia-se na minimização dos riscos econômicos para o agricultor.

Quanto as estratégias de irrigação geralmente variam de diferentes lâminas de aplicações e níveis críticos de água disponível no solo, bem como a utilização de irrigação com determinados limites de déficits (niveis de estresse) na qual a irrigação é iniciada, assumidos como um valor constante ou variáveis com a fenologia da cultura, ou a combinação de ambos. Muitos estudos mostram que os parâmetros ótimos de irrigação para cada estação são aqueles que maximizam o lucro liquido esperado e nem sempre estão relacionados com a melhor estratégia que maximiza a rendimento físico das culturas. Além disso, muitos agricultores são aversos ao risco, e a estratégia ótima neste caso, pode não ser aquela que resulta no maior lucro líquido e nem naquela de rendimento máximo, mas naquela que possibilite um menor risco de sua atividade.

Então, na análise, a cada estratégia, o modelo de crescimento de cultura simulará os rendimentos das culturas em resposta à irrigação para cada ano da série histórica climática. Pode-se então ajustar os resultados a uma distribuição 
estatística e então usa-la em um modelo de análise econômica. Os valores médios e desvios padrões da distribuição podem ser calculados e usados para comparar as estratégias. $\mathrm{Na}$ análise econômica deve-se definir a função objetivo, a partir do critério e as estratégias adotados, para ser otimizada, assumindo uma variação estocástica ou um valor fixo dos preços dos produtos e insumos.

O ultimo passo no processo de avaliação de estratégias é a estimativa do risco associado com as estratégias altemativas. A avaliação dos riscos é baseada na evidência de que a maioria dos agricultores são aversos ao risco. Isto é, eles podem querer reduzir o grau de incerteza que norteia os lucros líquidos. Uma pessoa aversa ao risco opta por determinada estratégia, somente se sentir que existe uma razoável probabilidade de ser compensada. No caso de um grande número de estratégias, um procedimento formal de estimativa de risco pode ser usado para reduzir o conjunto de estratégias alternativas para um subconjunto menor de estratégias eficientes.

Várias são as abordagens que podem ser usadas para a estimativa dos riscos dependendo do conhecimento da distribuição de probabilidade dos lucros líquidos e das atitudes de riscos do tomador de decisões. A análise de dominância estocástica envolve a comparação das funções de distribuição de probabilidade acumulada dos lucros líquidos para cada estratégia alternativa de irrigação. O objetivo é eliminar as estratégias dominadas para chegar no subconjunto de estratégias eficientes de menor risco do original conjunto de estratégias. O conjunto de estratégias eficientes incluem a preferida de todas as decisões possiveis cujo risco é consistente com a restrição imposta pelo critério de eficiência. Uma outra opção é o critério do risco calculado, onde o clima é um fator de incerteza, ou seja, envolve o cálculo de uma expectativa de perda e a comparação da mesma com o custo necessário para prevenir esta perda.

Os modelos de simulações de culturas e os procedimentos de avaliação de estratégias deste estudo podem ser generalizados para examinar outras variáveis que afetam decisões de irrigação ou para examinar outros tipos de decisões de produções. 


\subsection{APLICAÇÕES DE MODELOS PARA A OTIMIZAÇÃO DA IRRIGAÇÃO}

Muitos são os exemplos que demonstram a utilidade de modelos de simulação para a definição e análise de estratégias de irrigação em culturas para diferentes condições de clima e solo. Algumas destas aplicações incluem o uso do modelo CERES-maize para avaliar estratégias de irrigação do milho em Michigan e o uso do modelo SOYGRO para avaliar estratégias de irrigação com soja na Florida (Bogges et al., 1988). A Dominância estocástica foi o critério usado para avaliar o risco associado com estratégias alternativas. Duas relações gerais foram ressaltadas por estes autores a partir dos resultados obtidos. Primeiro, estratégias de maximização de lucro necessitam significativamente menor quantidade de água do que estratégias de máximo rendimento. Segundo, a irrigação é a única entrada de produção que reduz a variabilidade do rendimento relacionada ao clima. Estas relações enfatizam a necessidade de avaliar estratégias sob um amplo conjunto de condições de incertezas em ordem para estimar adequadamente as implicações de risco.

Faria et al. (1997), utilizaram o modelo BEANGRO para simulações de longo periodo afim de analisar os benefícios econômicos de diferentes estratégias de manejo de irrigação para a cultura do feijão no Estado do Paraná, Brasil. Simulou-se a produtividade e demanda de irrigação com base em oito níveis críticos de extração de água no solo (20 a 90\% de água disponivel no solo em etapas de $10 \%)$, juntamente a um nivel sem irrigação. $O$ critério de otimização utilizado para a definição da melhor estratégia foi o da maximização da renda líquida, assumindo-se preços do produto como fixo ou com variação estocástica. Seus resultados mostraram um acréscimo significativo da produtividade devido à irrigação, porém, observou-se respostas altamente variáveis em todos os niveis simulados. A renda líquida foi também variável, porém positiva em $75 \%$ dos anos para todas as estratégias em que se manteve o solo acima de $30 \%$ de água disponível. A estratégia de irrigar a cultura quando o solo atingir $60 \%$ de água disponivel proporcionou o máximo 
retorno econômico. A renda líquida proporcionada com o uso desta estratégia justifica a aplicação de irrigação em feijão no Estado do Paraná.

Algozin et al. (1988), usaram o modelo de simulação CERES-maize para generalizar as produtividades e os dados de irrigação para cada estratégia considerada para Michigan, em 30 estações de crescimento do milho. Estes autores chegaram a conclusão que a melhor estratégia, para a otimização do uso de água e energia, consiste do uso de irrigação com aplicações pequenas e frequentes de água.

Ritchie (1985) usou o modelo de crescimento de milho CERES-maize, para avaliar os riscos associados com a agricultura dependente das chuvas.

Algozin et al. (1988) também usaram o modelo CERES-maize para selecionar estratégias de planejamento de irrigação baseados em critérios econômicos. Neste seu estudo, a avaliação de estratégias envolveu a aplicação de análise de eficiência estocástica para determinar o risco econômico.

Barfield et al. (1983), apresentaram um procedimento para prognosticar a economia do planejamento da irrigação em regiões úmidas. Estes pesquisadores usaram o modelo SIMAIZ para determinar a resposta de produtividade para várias estratégias de manejo da água e os riscos associados com cada estratégia. O principal objetivo de sua pesquisa foi avaliar o relacionamento entre o rendimento, uso da água, e energia resultante da implementação de várias estratégias de aplicação de irrigação no sul de Michigan.

Villalobos et al. (1989), usaram modelo de simulação de crescimento de culturas (milho) juntamente com um gerador de dados diários de chuva e modelos de balanço hídrico para determinar datas e quantidades de irrigação. Neste estudo, os autores propõem um método de prever o manejo da irrigação baseado em simulações de desenvolvimento da cultura e em níveis de probabilidade para datas de irrigação ideais e subideais. O manejo da irrigação simulado diferiu substancialmente de um ano para outro devido a quantidade $e$ distribuição da chuva. Estes autores comentam que os resultados das simulações podem ser usadas para desenvolver manejos estocásticos de 
irrigação que dão as datas e quantidades de irrigação uma vez que o usuário escolhe um certo nível de probabilidade de exceder a depleção admissivel de água no solo. O número de aplicação e a profundidade de aplicação para cada estação é sensivel ao nível de risco aceitável ao atraso da irrigação.

Allen et al. (1971), conceberam um modelo para testar a aplicação de um modelo de decisão de manejo de irrigação com a incorporação de conceitos básicos de calculo de riscos. Dois métodos foram usados para calcular os custos da irrigação. O critério de decisão através do método do modelo de simulação (princípio do risco calculado) foi aplicado com os dados de três estações de crescimento. Os resultados foram comparados com o critério de irrigar quando a água no solo atinge $50 \%$ da água disponível. Os resultados mostraram que o critério do modelo resulta em menores custos totais e mais perdas de rendimento, porém sendo mais econômica (menor risco).

Swaney et al. (1983) desenvolveram uma metodologia, através de modelos dinâmicos de simulação de crescimento de cultura, que foi usada para avaliar o lucro esperado e os benefícios no rendimento a partir de decisões em tempo real. O modelo SOYGRO foi usado para demonstrar esta abordagem para o cultivo da soja em regiões úmidas. $O$ modelo foi inicialmente usado para determinar a estratégia ótima, baseada em 17 anos de dados climáticos. 0 problema de otimização foi formulado para determinar o nivel crítico de depleção de água no solo e a quantidade de água por aplicação que maximiza o lucro líquido esperado com simulação de longo período. Os valores ótimos foram obtidos de um conjunto de combinações de lâminas de irrigação (1 a 7 $\mathrm{cm}$ ) e níveis de depleção de água no solo (0 à 100\%), definindo cada estratégia. O máximo valor de lucro localizou-se próximo aos $70 \%$ de água disponivel com $1 \mathrm{~cm}$ de lâmina de irrigação por aplicação. Esta estratégia foi usada como base para implementar o algoritmo interativo de decisão em tempo real descrito em sua pesquisa.

Estratégias para otimização de irrigação para a cultura do milho com aspersão em pivô central foram analisadas por Howell et al. (1989). O modelo 
CERES-maize foi modificado e calibrado para simular as respostas da cultura à diferentes lâminas de irrigação e níveis de depleção de água no solo, para o planalto sul dos Estados Unidos.

Coleman et al. (1987) utilizaram o modelo de crescimento de cultura SOYGRO modificado para simular rendimentos e desenvolver estratégias de irrigação por pivô central em um solo arenoso na região sul dos E.U.A. As estratégias de irrigação incluíram níveis críticos de água disponível no solo e níveis de reabastecimento definidos através de porcentagens da capacidade máxima de água disponível no solo com base na fenologia das culturas. A estratégia dependente da fenologia resultou maiores médias simuladas de retornos econômicos do que as estratégias de níveis críticos ou lâminas constantes.

Estratégias de manejo de irrigação por aspersão foram simuladas pelo modelo CERES-maize para um período de 20 anos usando uma série histórica de Bushland, Texas (Howell et al., 1989), para estudar interações entre quantidades de aplicações, depleção admissível de água no solo e capacidades de suprimento do sistema de irrigação. As simulações ilustram que a irrigação por aspersão do milho nas condições do experimento requer uma capacidade de irrigação líquida de no mínimo $8 \mathrm{~mm} . \mathrm{d}^{-1}$ para evitar reduções de rendimento.

\subsection{CRITÉRIOS ESTATISTICOS DA TEORIA DA DECISÃO}

Para a escolha de uma estratégia ideal, levando em consideração o risco inerente à cada alternativa possível, recorre-se à Teoria da Decisão. Esta teoria envolve as probabilidades subjetivas sobre a ocorrência de eventos incertos, além da avaliação pessoal dos possíveis resultados (Salomão, 1990). Reunindo-se ambos os aspectos, tem-se os critérios de escolha. Neste estudo, foram abordados, o método da Média-variância (Tobin-Markowitz) e a Dominância Estocástica (Quirk-Saposnick), que consideram algumas características de 
decisão preconizadas pela função utilidade quadrática, onde o tomador de decisão prefere sempre maior retorno e é averso ao risco.

O método da Média-variância pressupõe que o tomador de decisão se baseia nas propriedades da função de probabilidade do retorno, para a escolha entre alternativas arriscadas. Os parâmetros relevantes desta função, para a tomada de decisão, são a média (E) e a variância (V), que são o primeiro e segundo momentos da distribuição estatística. É com este último que a noção de risco é incorporada. Neste caso, para a escolha entre alternativas de riscos distintos, é necessário que, além dos maiores retornos, a alternativa escolhida seja aquela com menores niveis de risco. Caso isto não ocorra, as alternativas são consideradas não comparáveis entre si. Portanto, fora destas condições, não é possivel decidir, segundo este critério, sendo uma das desvantagens da sua aplicação, ficando a escolha a cargo do tomador de decisão, em função do seu grau de aversão ou propensão ao risco.

A análise de Dominância Estocástica baseia-se na comparação entre as distribuições cumulativas de probabilidade dos retornos, que estão associadas às diferentes alternativas em questão (estratégias especificas). Considera a distribuição total dos resultados, ao invés de apenas os dois primeiros momentos da distribuição. Neste método, a alternativa preferida é aquela que possibilita maiores retornos, e oferece menor probabilidade do nivel de retorno cair abaixo de um determinado valor estipulado inicialmente. No caso em que as distribuições cumulativas das alternativas se cruzam, não podemos decidir imediatamente. Isto significa que cada uma delas apresenta melhores resultados até um determinado nível de retorno, a partir do qual outra alternativa passa a ser mais interessante. Neste caso, recorre-se a maiores graus de dominância estocástica, para que se possa proceder a escolha. É necessário que a alternativa dominante tenha retorno e limite inferior da distribuição cumulativa das probabilidades, mais elevados que as alternativas dominadas. Isto nem sempre ocorre, e constitui-se uma limitação do método (Pacheco, 1985; Moutinho, 1977). 


\section{MATERIAIS E MÉTODOS}

As análises de estratégias e riscos para o milho "safrinha", cultivar $\mathrm{XL}-520$, foram realizadas a partir de simulações de longo período (Sub-rotina "SEASONAL") com o modelo CERES-Maize, de acordo com as informaçōes e procedimentos obtidos junto ao IAPAR (Instituto Agronômico do Paraná) e literatura disponivel, que serão descritos a seguir.

\subsection{DESCRIÇÃO DO MODELO CERES-Maize}

O modelo CERES-maize (Jones e Kiniry, 1986) é um modelo determinístico, preditivo, com intervalo de cálculo diário, concebido para simular o crescimento, desenvolvimento e rendimento da cultura do milho em escala de campo, assim como o balanço hídrico do solo e a dinâmica do nitrogênio durante o ciclo da cultura. O modelo é usado para pesquisa básica e aplicada dos efeitos de clima (regime térmico e hídrico) e manejo (época de plantio, adubação e irrigação) no crescimento e rendimento do milho. A Figura a seguir ilustra a estrutura básica do modelo CERES-maize.

Os inputs requeridos pelo CERES-maize estão prontamente disponiveis ou são facilmente calculados. Estes inputs incluem informações diárias de clima (radiação solar, temperaturas máxima e mínima e chuva), dados de caracterização do solo e condições iniciais de umidade e status de nitrogênio no solo. Os inputs de manejo requeridos incluem data e profundidade de plantio, população, variedade da cultura, e aplicações de fertilizantes e de irrigação. 


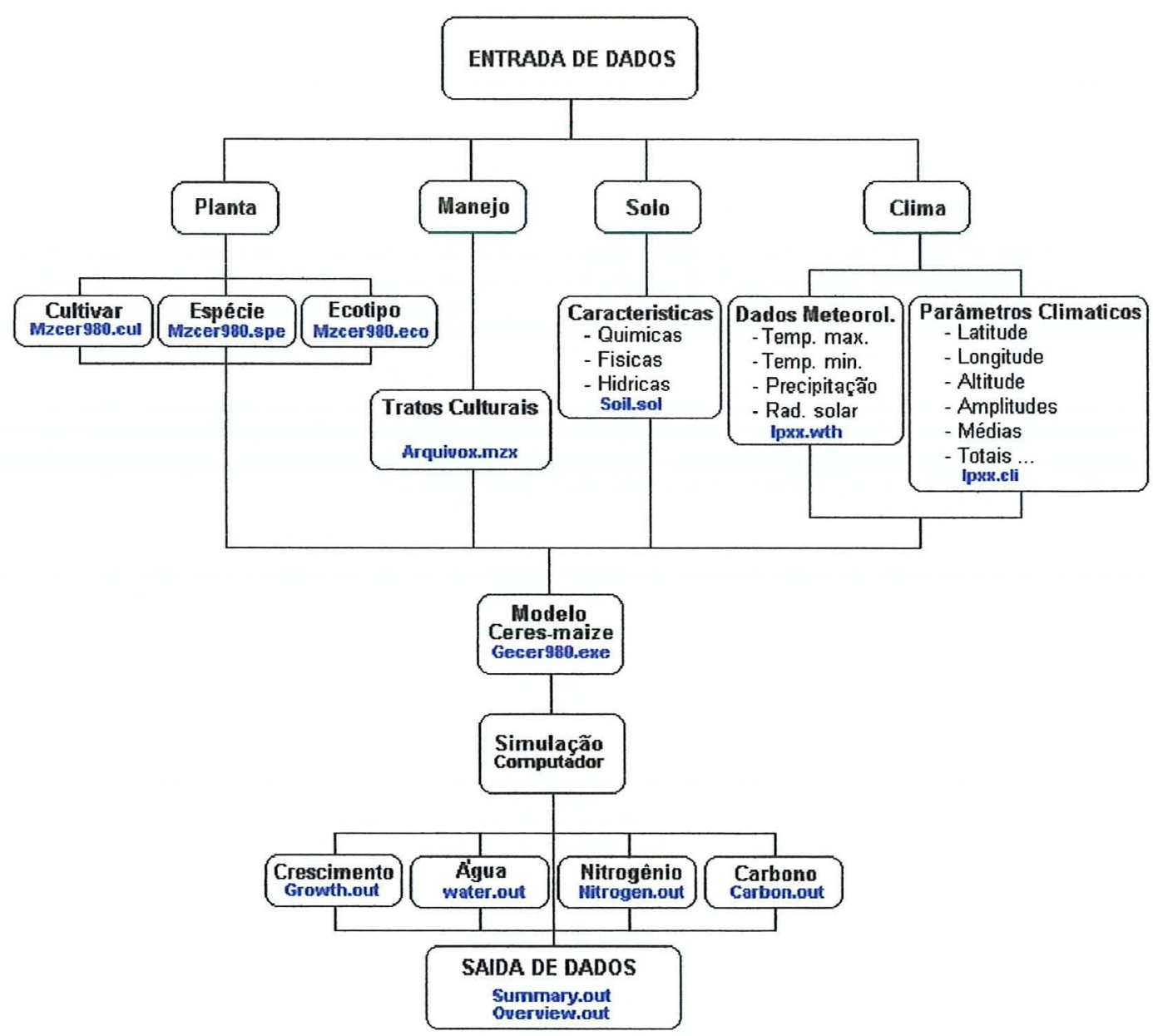

Figura 3.1. Estrutura e fluxo de informações no modelo CERES-Maize

A simulação do rendimento da cultura enfoca três aspectos importantes: a duração do crescimento, a taxa de crescimento e a influência de "estresses" nestes dois processos. Estresses podem ocorrer na forma de deficiências de água e nutrientes do solo ou extremos de temperatura.

Uma característica deste modelo é sua capacidade para incluir informação de uma cultivar específica sendo possível a predição das variações na fenologia da planta e características de componentes do rendimento e as suas interações com o clima. O modelo permite calcular a duração do ciclo de crescimento de diferentes cultivares através da abordagem da soma de unidades de calor para o seu desenvolvimento. 
Segundo Ritchie (1998), o crescimento de biomassa é calculado usando a aproximação da eficiência no uso da radiação; a biomassa produzida é dividida entre folhas, talos, raizes, espigas e grãos. A proporção dividida a cada órgão em crescimento é determinada pela fase de desenvolvimento e condições gerais de crescimento. Os princípios de partição são baseados em um conceito de "fonte e dreno" e são modificados quando deficiências de água e de nutrientes acontecerem. Rendimentos de cultura são determinados como um produto do número de grão por planta vezes o peso médio de sementes na maturidade fisiológica. Os modelos CERES foram testados sob uma gama extensiva de ambientes. Embora haja melhorias que podem serem feitas nos procedimentos de simulação, os resultados mostraram que quando o clima, cultivar e informação de manejo são razoavelmente quantificados, os resultados de rendimento normalmente estão dentro de limites aceitáveis de $\pm 5 \%$ a $15 \%$ dos rendimentos medidos.

Segundo Jones \& Kiniry (1986) os efeitos causados por ervas daninhas, insetos, fitopatógenos, deficiências de nutrientes que não o nitrogênio, toxidez, bem como eventos catastróficos não são considerados pelo modelo.

O modelo é regido por várias seqüências de dados que simulam os processos biológicos e físicos envolvidos na produção de milho. Estes processos incluem desenvolvimento fenológico, crescimento, acumulação e partição de biomassa, balanço de água do solo, e dinâmica de $\mathrm{N}$ no solo .

Uma descrição mais detalhada do funcionamento deste modelo é apresentada por Jones \& Kiniry (1986); Lima (1995); Ritchie et al. (1998).

\subsubsection{EVENTOS FENOLÓGICOS}

A duração dos diferentes estágios de crescimento foi chamado no modelo CERES de desenvolvimento de fases. O desenvolvimento de fases é afetado principalmente pelos fatores genéticos e ambientais. São considerados 
a sensibilidade ao fotoperíodo e os efeitos da temperatura como fatores ambientais mais importantes a determinar os estágios e ciclo da cultura (Kiniry, 1991). O feito da temperatura é computado pela soma de unidades térmicas de desenvolvimento que é chamado de "tempo térmico". O tempo térmico é obtido pela expressão abaixo descrita por Ritchie et al. (1998),

$$
t d=\sum_{i=1}^{n}(\bar{t} a-T b)
$$

onde, td é o tempo térmico $\left({ }^{\circ} \mathrm{C}\right) ; \bar{t} a$ é a temperatura média do $\operatorname{ar}\left({ }^{\circ} \mathrm{C}\right)$; Tb é a temperatura base na qual o crescimento cessa e $n$ é o número de dias de observações de temperaturas usadas no somatório.

A base teórica para essa abordagem é que, dos processos envolvidos no desenvolvimento da cultura, todos são sensíveis à temperatura do ar pois, a mesma é o principal controlador da evolução dos estádios de crescimento da planta e para muitas espécies esses estádios podem estar vinculados a um certo número de unidades térmicas acumuladas, cabendo enfatizar que a resposta das plantas à temperatura do ar obedece a limites (inferior ou superior) e é extensiva ao desenvolvimento total da cultura.

Os fatores genéticos que determinam os aspectos fenológicos ao longo do ciclo das cultivares são representados pelos "coeficientes genéticos", os quais assumem que uma característica comum a todas as variedades de milho pode variar quantitativamente, explicando as diferentes adaptações (Salvador, 1993).

Segundo Hoogenboom et al. (1994), para o milho estes coeficientes são os seguintes:

- P1: Este coeficiente esta associado a duração do período vegetativo, e representa a soma térmica (graus-dia acumulados) desde a emergência até o final da etapa vegetativa, e cuja a temperatura base é igual a $8^{\circ} \mathrm{C}$.

- P2: Este coeficiente esta associado à sensibilidade ao fotoperíodo, e representa os dias de atraso na iniciação da floração masculina para cada hora 
de incremento do fotoperíodo acima de 12,5 horas.

- P5: Coeficiente associado à duração da etapa reprodutiva, representa a soma térmica (graus-dia acumulados) desde o florescimento ao ponto de maturidade fisiológica do grão.

- G2: relacionado ao número máximo de grãos por espiga ou número potencial de grãos.

- G3: relacionado com a taxa de enchimento de grão sob condições ótimas de crescimento, ou taxa potencial diária.

Estes parâmetros fisiológicos são fundamentais porque têm forte influência na simulação do crescimento e desenvolvimento da planta. Valores para tais parâmetros são obtidos em laboratórios ou experimentos a nível de campo, através da medição do número de folhas, datas de emergência, florescimento e ponto de maturação fisiológica, valores diários de graus-dia, número e peso de grãos. Jones \& Kiniry (1986) apresentaram valores destes parâmetros para várias cultivares. Os valores destes coeficientes são particulares a cada variedade permitindo analisar a adaptação destes a diversos ambientes. Os valores destes coeficientes para a cultivar XL-520 foram obtidos de uma calibração realizada por Lima (1995), como já mencionado.

A ocorrência das diferentes fases fenológicas descritas no modelo representam intervalos de crescimento da planta delimitados por diferentes eventos fisiológicos. O desenvolvimento de fases nos modelos CERES quantifica a idade fisiológica da planta e descreve a duração de nove estágios de crescimento (Tabela 3.1). Com exceção da duração do periodo de pré-semeadura (fase 7) que é especificado pelo usuário (datas do início da simulação e semeadura), o modelo é que simula a duração das fases de crescimento.

As principais condições de contorno assumidas pelo modelo referentes à fenologia do milho de acordo com Kiniry (1991), são descritas a seguir:

A temperatura sob a qual o crescimento é limitado (temperatura base), é $8^{\circ} \mathrm{C}$ para todas as fases, exceto para a fase de germinação à emergência que é $10^{\circ} \mathrm{C}$. 
Tabela 3.1. Estágios de Crescimento de culturas no modelo CERES e os órgãos que crescem durante essas fases.

\begin{tabular}{|c|c|c|}
\hline Estadio $n^{\circ}$ & Duração & Órgãos em crescimento \\
\hline 7 & Período de pré-semeadura & \\
\hline 8 & Semeadura à germinação & \\
\hline 9 & Germinação à emergência das plântulas & Raiz \\
\hline 1 & Emergência ao final da fase juvenil & Folha, raiz \\
\hline 2 & $\begin{array}{l}\text { Fim da fase juvenil ao inicio da floração } \\
\text { masculina }\end{array}$ & Folha, talo, raiz \\
\hline 3 & $\begin{array}{c}\text { Inicio da floração masculina à } \\
\text { emergência do estigma na espiga }\end{array}$ & $\begin{array}{l}\text { Folha, talo, raiz } \\
\text { Talo, espiga }\end{array}$ \\
\hline 4 & $\begin{array}{l}\text { Emergência do estigma na espiga ao } \\
\text { início enchimento de grão }\end{array}$ & Talo, espiga, raiz \\
\hline 5 & $\begin{array}{c}\text { início enchimento de grão - maturidade } \\
\text { fisiológica }\end{array}$ & Grão, raiz \\
\hline 6 & Maturidade fisiológica - colheita & \\
\hline
\end{tabular}

Fonte: Ritchie et al. (1998).

Quando a disponibilidade de água no solo não é limitante, a duração da fase semeadura-emergência requer um dia até a germinação e logo uma soma térmica de $45^{\circ} \mathrm{C}$.dia (temperatura base igual a $10^{\circ} \mathrm{C}$ ) para a emergência da planta com uma profundidade de semeadura de $5 \mathrm{~cm}$.

A velocidade do desenvolvimento de várias fases aumenta linearmente desde a temperatura base até $34^{\circ} \mathrm{C}$, depois decresce linearmente até zero quando a temperatura aumenta de 34 a $44^{\circ} \mathrm{C}$. De forma semelhante, assumese que a taxa de iniciação de folhas e aparecimento de apices foliares muda linearmente entre as duas faixas de temperatura.

A soma térmica necessária para a iniciação de cada primórdio foliar é de $21^{\circ} \mathrm{C}$. dia e para o aparecimento de cada ápice foliar é de $38,9^{\circ} \mathrm{C}$. dia.

Durante a fase juvenil, tanto a taxa de iniciação de primórdios como a duração dessa fase são dependentes da temperatura.

Uma vez que a soma térmica do coeficiente genético $\mathrm{P} 1$ tenha sido alcançada, o desenvolvimento do ápice fica independente da temperatura e começa a etapa sensivel ao fotoperíodo. Todos os genótipos iniciam a floração masculina 4 dias depois do começo dessa fase em fotoperíodos iguais ou 
menores que 12,5 horas. Para fotoperiodos maiores, o retardamento produzido na data de floração masculina é calculado com o coeficiente genético P2 (sensibilidade ao fotoperíodo) e o número de horas de sol (fotoperíodo).

A duração da fase sensivel ao fotoperíodo é estritamente dependente do fotoperiodo. No entanto, a iniciação de primórdios de folhas é ainda dependente da temperatura. Nessa fase as altas temperaturas aumentarão a velocidade de iniciação de folhas, porém, isso não ocorre para a taxa de desenvolvimento de folhas no ápice, resultando num maior número total de folhas e num retardamento da emergência da espiga.

A data de floração masculina é calculada pela soma térmica e pelo fotoperíodo. Nesse momento acaba a iniciação de primórdios foliares.

O número total de folhas surge do número de primórdios foliares iniciados entre a emergência e a iniciação da floração masculina.

A data de emergência da espiga é a mesma do final do crescimento de folhas e fica determinada pelo número total de folhas e a velocidade de aparição de ápices foliares.

Três fases entre a emergência da espiga e o ponto de maturidade fisiológica são simuladas: a) fase inicial nomeada "lag" (170 ${ }^{\circ} \mathrm{C}$.dia); b) fase de crescimento linear que finaliza quando $95 \%$ dos graus-dia necessários tenham sido acumulados; c) fase final que requer o restante $5 \%$ dos graus-dia. De acordo com dados experimentais de campo, a soma térmica de P5 varia de 665 ate $940^{\circ} \mathrm{C}$.dia (base $8^{\circ} \mathrm{C}$ ).

\subsubsection{PRODUÇÃO DE BIOMASSA E ASPÉCTOS DO CRESCIMENTO}

A produção de biomassa é calculado usando o conceito de eficiência de uso de radiação (RUE), tendo como base os resultados de pesquisas relatados por Monteith (1977); Hesketh e Baker (1967); Norman e Arkebauer, (1991), Spiertz e Van de Haar (1978), e Puckridge e Rathowsky (1971) citados por Ritchie et al. (1998). 
Estes pesquisadores demonstraram que a produção de biomassa era relacionada linearmente com a interceptação de luz sazonal cumulativa para várias culturas sob condições de água e nutrientes adequados.

Então no modelo CERES o acúmulo de biomassa para o crescimento da planta está relacionado com a absorção de radiação fotossinteticamente ativa (PAR). A PAR calculada no modelo é a quantidade de luz disponivel para interceptação da cultura e foi assumido que seja a metade $(50 \%)$ da radiação solar diária (Monteith, 1977). Assim, o crescimento depende da quantidade de PAR recebida e da superfície foliar disponível para sua interceptação. A produção potencial de biomassa em um dia (PCARB) é então calculada por,

$$
P C A R B=R U E . I P A R
$$

onde, RUE é a eficiência de uso da radiação (para milho considera-se $5 \mathrm{~g} \cdot \mathrm{MJ}^{-1}$ ); IPAR é a fração da PAR interceptada pelas plantas, obtida por,

$$
I P A R=P A R \cdot\left(1-e^{-k \cdot I A F}\right)
$$

onde, $k$ é o coeficiente de extinção (igual a 0,65 para o milho); IAF é o índice de área foliar .

A área foliar de uma planta é o produto da taxa de aparecimento de folha e a taxa de expansão do crescimento das folhas.

$O$ índice de área foliar pode ser calculado da área total de folha da planta (PLA) e a área de senescência de folhas SENLA como segue

$$
I A F=(P L A-S E N L A) \cdot P L A N T S .0,0001
$$

onde, PLANTS é a população de planta.

A senescência da folha está ligado ao desenvolvimento da folha da planta. Assumindo que nenhum outro estresse causa senescência de folha precocemente, a senescência começa nas folhas mais velhas. Este tipo de senescência pode ser explicado pelo sombreamento das folhas mais velhas, mais 
baixas, pelas folhas superiores, mais novas, e por dano físico recebido pelas folhas mais velhas como resultado da expansäo do talo e rachadura da bainha da folha. Então a área foliar de senescência (SENLA) é determinada por,

$$
S E N L A=S E N L A+P L A L R
$$

onde, PLALR é a taxa de perda de área foliar da planta, determinada por

$$
P L A L R=[P L S C(L N-a)-P L S C(L N-a+1)] . T I
$$

onde PLSC é a área foliar cumulativa no período que cada folha do talo principal alcança o tamanho total, $L N$ é o número de folha no talo principal acumulado desde a emergência, a é o número de folhas que o talo pode reter, e Tl é a fração de filocromo diária.

Quando déficits de água no solo estão presentes, a área foliar de senescência da planta é aumentado por um fator relacionado a intensidade do déficit.

A área foliar cumulativa total de planta $(P L A)$ é atualizada então com o crescimento diário (PLAG):

$$
P L A=P L A+P L A G
$$

Da taxa de crescimento de área foliar do talo principal da planta, uma primeira aproximação da taxa de crescimento de área foliar total da planta (PLAG) pode ser determinado.

A área foliar potencial no talo principal ( $P L A M)$ pode ser calculada como uma função do número de folha da extremidade ( $L N)$ usando a equação,

$$
P L A M=6000 \cdot e^{\left[-10.34 \cdot e^{(-P L C . L N)}\right]}
$$

onde, PLC é uma constante ajustada empiricamente. A taxa de crescimento de expansão diária potencial do talo principal (PLAMO) é calculado como a diferença em PLA entre dois dias sucessivos obtidos usando $L N$ nos dois dias. Expansão de folha atual do talo principal (PLAGM) é obtido multiplicando a taxa 
de expansão potencial por uma fração que varia entre 0 e 1 relativo a temperatura não-ótima (TEMF) ou déficit hídrico (SWDF2) ou déficit de nitrogênio (NDEF2). Os fatores de déficits de água e nitrogênio usados para o crescimento de expansão são mais sensiveis que os fatores de déficits de crescimento de biomassa e reduzem crescimento através da seguinte expressão:

$$
P L A G M=P L A M O \cdot \min (T E M F, S W D F 2, N D E F 2)
$$

onde, min indica o valor mínimo dos fatores em parêntese usado para modificar o crescimento de expansão folhar.

Para converter a taxa de crescimento de área foliar em valores que descrevem a massa de crescimento obtida, considera-se que os únicos fatores limitantes do crescimento potencial de área foliar é o déficit de água no solo. Este déficit hídrico no solo, SWDF2, é obtido da rotina do balanço hídrico do solo. Para determinar a quantidade de folhas que pode crescer, a relação da área foliar por peso de assimilados (AWR) é calculado. O AWR no estádio 1 inclui toda biomassa da parte aérea da planta que só consiste em folhas uma vez que o talo tem uma contribuição desprezível para a biomassa da planta neste estádio. O AWR para o inicio do crescimento vegetativo, é descrito pela equação

$$
A W R=150-0.075 . T D U
$$

onde, TDU são as unidades térmicas de desenvolvimento.

Então no Estádio 1, o modelo não permite AWR variar exceto com o envelhecimento da planta. Isto é, entretanto, somente uma consideração para o crescimento neste estádio uma vez que AWR não é usado após o estádio 1.

O crescimento foliar potencial (GROLF) é a massa de assimilados exigida para suportar aquela quantidade de crescimento de expansão diário na planta e é expressado por

$$
G R O L F=\frac{P L A G}{A W R}
$$


É assumido então que o crescimento de raiz ocorre com o remanescente da provisão de assimilados diária.

$$
G R O R T=C A R B-G R O L F
$$

Se o crescimento de raiz é maior do que $35 \%$ de CARBO no estádio de crescimento 1, é assumido que a planta tem um adequado suprimento de assimilados para que o crescimento de folha proceda em sua taxa potencial (Gregory et al. 1978). Se GRORT é menor que 35\% de CARBO, então GROLF é reduzido tal que seu valor é $65 \%$ de CARBO e GRORT é então $35 \%$ de CARBO. Quando isto acontece, um valor novo para PLAG é determinado por

$$
P L A G=G R O L F \cdot A W R
$$

Quando estresses devido à temperaturas extremas ou à deficiências de água e nitrogênio ocorrem, além de acelerar a senescência de folhas, a produção de biomassa diária atual (CARBO) será menor que a PCARB.

O efeito da temperatura é considerado no modelo através de um fator de redução (PRFT) obtido pela equação,

$$
P R F T=1-T c .(T D A Y-T o)^{2}
$$

onde, Tc é uma constante empírica de ajuste; To é a temperatura ótima para a fotossintese (para milho é igual a $26^{\circ} \mathrm{C}$ ); TDAY é a temperatura média diária, obtida pela média ponderada entre as temperaturas máxima (Tmax) e mínima (Tmin), tal como,

$$
T D A Y=0,75 . T \max +0,25 . T \min
$$

A equação para calcular a produção de biomassa diária (CARBO), usa o conceito da Lei dos Fatores Limitantes para reduzir PCARB, tal como

$$
C A R B O=P C A R B \cdot \min (P R F T, S W D F 1, N D E D 1,1)
$$


onde, min indica que o valor mínimo da lista em parêntese será usado, SWDF1 é um fator usado para diminuir PCARB devido a déficit hídrico; NDEF1 é um fator para diminuir PCARB devido a déficit de nitrogênio.

Estes fatores de estresses assumem valores entre 0 e 1 , onde 1 representa o fator não-limitante e 0 representa o máximo de estresse. Isto é convertido para uma base por planta quando dividido pela população de planta (PLANTS). Deste modo uma única planta crescendo em competição com outras plantas é representada logicamente. Os modelos assumem que todas as plantas são a mesma e igualmente espaçadas nas linhas.

\subsubsection{PARTIÇÃO DE ASSIMILADOS}

A partição de assimilados é um processo dinâmico requerendo na modelagem vários mecanismos de re-alimentação. Como já mencionado a produção de biomassa depende da radiação fotossinteticamente ativa que é interceptada pela área foliar das plantas. A biomassa produzida é dividida entre folhas, talos, raízes, espigas e grãos. A proporção dividida a cada órgão que está crescendo é determinada pela fase de desenvolvimento e condições gerais de crescimento. Os princípios de partição são baseados no conceito de "fonte e dreno" e são modificados quando deficiências de água e de nutriente acontecerem.

A maior dificuldade associada a produção de biomassa foi a falta de conhecimento relativo à fração de assimilados destinados às raízes.

Segundo Ritchie et al. (1998) os rendimentos de cultura nos modelos CERES são determinados como um produto do número de grão por planta vezes o peso médio de sementes quando na maturação fisiológica. Os números de grãos são calculados do crescimento de biomassa na parte aérea durante uma fase crítica do ciclo de crescimento de planta num tempo térmico fixo antes da antese. $O$ peso de grão em todos os modelos CERES é calculado como uma função da taxa de crescimento ótima da cultivar específica multiplicado pela duração do enchimento de grão. $O$ enchimento de grão é reduzido abaixo do 
valor ótimo quando o suprimento de assimilados da produção de biomassa ou de biomassa móvel armazenado no talo é insuficiente.

Segundo Jones \& Kiniry (1986), os ganhos de biomassa parcial e total são resultantes do balanço de carbono, sendo função da fotossíntese total, respiração de manutenção e da eficiência de conversão de carbohidratos em matéria seca. As taxas de variação da matéria seca nas folhas, ramos e raízes, são funções dos coeficientes de partição de fotoassimilados para as diferentes partes da planta, que variam com o estádio fenológico da cultura, das quantidades de proteínas mobilizadas diariamente para as partes da planta, e das quantidades de carbohidratos mobilizadas para as diferentes partes da planta.

A partição dos fotoassimilados é função da matéria seca nova produzida em cada componente da planta, fator de partição para cada tecido da planta, eficiência de conversão, fotossíntese total e respiração de manutenção. Segundo Ritchie et al. (1998), durante a fase vegetativa, todos os assimilados são alocados para os tecidos vegetativos das folhas, ramos e raízes. No estádio reprodutivo, novos drenos são formados, alocando parte dos assimilados.

A biomassa total (BT) da cultura segundo descrito por Ritchie et al. (1998), é o produto da taxa média de crescimento $(\mathrm{g})$ e a duração de crescimento $(d)$ :

$$
B_{T}=g \times d
$$

O rendimento econômico da cultura é a fração de $\mathrm{B}_{\mathrm{T}}$ que é dividido ao grão. Esta fração pode variar de praticamente zero para culturas com estresses severos em tempos críticos para mais que 0.5 para culturas que estão crescendo sob condições ótimas. Assim, a partição de BT no rendimento leva em conta ambos os efeitos de crescimento e desenvolvimento.

Crescimento e desenvolvimento apresentam aspectos distintamente diferentes a serem considerados. O crescimento de massa é dependente da quantidade de PAR recebida do sol e a quantidade de área foliar disponivel para a absorção da PAR para fotossíntese. A outra dimensão do crescimento, a 
expansão da área ou volume de partes da planta, não é controlada pela quantidade líquida de carbono fixada. Fatores ambientais e estresse afetando a expansão de células são diferentes daqueles que afetam o crescimento de massa. Isto é por que a planta crescendo vegetativamente a temperaturas diferentes e em niveis de radiação semelhantes, poderá, com o tempo, ter um tamanho e massa diferentes. Estas diferenças em massa e expansão sugerem que os padrões de partição da planta sejam alterados de algum modo para acomodar a diferença em tamanho de planta quando a taxa de assimilação líquida seja aproximadamente o mesmo quando normalizado para a área de folhas que absorvem a PAR.

A duração de crescimento de planta também tem duas características distintamente diferentes, chamadas desenvolvimento de fases e morfológico. Desenvolvimento de fases envolve mudanças nos estágios de crescimento e é quase sempre associado com as principais mudanças nos padrões de partição da biomassa. O desenvolvimento de fases é um dos principais processos de planta com um alto grau de diversidade de cultivar. Esta diversidade de cultivar possibilita a oportunidade para selecionar cultivares que tem o comprimento da estação de crescimento sincronizado com a provisão de água ou comprimento de estação quente para um local particular. Esta característica é de maior importância na análise de riscos associada com produção de cultura.

$O$ desenvolvimento morfológico refere-se ao inicio e fim do desenvolvimento de vários órgãos da planta dentro do seu ciclo de vida. Características morfológicas são usadas para prover uma estimativa do número de folhas, caules, e grãos que serão produzidas por uma planta. O fator ambiental principal que afeta ambas as taxas de desenvolvimento de fases e morfológicas é a temperatura da parte em crescimento da planta. As funções de resposta da temperatura dos dois processos de desenvolvimento podem ser diferentes, entretanto, as características de cultivar que afetam a resposta da planta ao fotoperíodo também são importante determinante da duração de crescimento além da influência de temperatura. 


\subsubsection{BALANÇO HIDRICO DO SOLO}

Segundo Ritchie et al. (1998), o balanço hídrico do solo com a cultura em estudo é realizado por uma sub-rotina do modelo determinando diariamente os efeitos de déficits de água no solo sobre o crescimento da planta e redução do seu rendimento. Informações relativas a redistribuição de água no perfil do solo devido à chuva, irrigação e drenagem, além da evapotranspiração, evaporação e transpiração da planta pode ser obtida neste balanço.

No modelo CERES-maize, o balanço de água do solo é distribuído em camadas (até 10) do perfil do solo. O usuário designa o número de camadas e a profundidade de cada camada. A água em cada camada varia entre um limite inferior e um limite superior que é a umidade de saturação. A água infiltrada da chuva e/ou irrigação vai preenchendo camada por camada de cima para baixo, até que seja atingido sua capacidade de armazenamento, sendo o excesso contabilizado como drenagem profunda, a redistribuição da água nas camadas é então estimada diariamente. Uma parte da água que não infiltrou no perfil do solo é considerada como escoamento superficial. A drenagem é controlada pela camada de solo que drena mais lentamente ocorrendo quando o conteúdo de água está entre a saturação e a capacidade de campo (Ritchie, 1998).

O método do "número da curva" do SCS (Serviço de Conservação do Solo) dos EUA foi adaptado para estimar o escoamento superficial e indiretamente a infiltração de água no solo decorrentes de chuvas ou irrigações. Segundo Jones \& Kiniry (1986) o método pressupõe quatro grupos de solos quanto às suas características hidrológicas, que apresentam diferentes valores de número da curva refletindo no escoamento e infiltração de água estimados.

Os solos em estudo foram classificados no grupo de solos com boas condições hidrológicas (grupo B), cujo número de curva inicial é igual a 76 .

O modelo assume que o conteúdo de água de qualquer camada de solo particular pode diminuir devido a evaporação de solo, absorção de raiz, ou fluxo de água para uma camada adjacente. Os limites para os quais a água pode 
aumentar ou diminuir são entradas para cada camada de solo. Estes limites são o limite inferior de disponibilidade de água de planta ( $L L(L)$ ), o limite superior de drenagem (capacidade de campo) (DUL(L)), e o conteúdo de saturação de água no campo (SAT(L)). Outros inputs de solo necessários no modelo incluem o albedo do solo (SALB), o limite superior do primeiro estágio de evaporação de solo (U), uma constante para calcular a taxa de drenagem (SWCON), e um número de curva (CN2) usado para calcular o Run-off (escoamento Superficial) e infiltração da água no solo. Se a água de irrigação é aplicada ao solo que está sendo simulado, então o dia do ano da irrigação (JDIA(J)) e a quantia de irrigação (AIRR(J)) são lidos para o número de irrigações (NIRR) especificado nos dados. Quando a rotina de balanço de água no solo inicia na data especificada pelo começo de dados de clima, várias variáveis têm que ser inicializadas com alguma lógica razoável. Esta inicialização é feita na subrotina onde propriedades do solo são lidas de um arquivo e são inicializadas (SOILRI).

A absorção de água pela raiz no CERES-maize é calculada usando a "lei dos fatores limitantes" por meio da qual a resistência de solo, a resistência de raiz, ou a demanda atmosférica dominam a taxa de fluxo de água nas raízes. A maioria dos detalhes desta aproximação foi discutido por Ritchie (1985). As taxas de fluxo são calculadas na base de movimento de água para uma única raiz. A máxima absorção diária de água pelas raízes em uma camada é assumido que seja 0.03 $\mathrm{cm}^{3}$ de água por $\mathrm{cm}$ de raiz. Este valor ajusta o limite superior de absorção de água pelas raízes como sendo limitado pela resistência axial da raiz. $A$ absorção potencial de água pela raiz é influenciado pelo fluxo de água do solo na camada.

As equações para predizer a evaporação são principalmente aquelas usadas no modelo de Ritchie (1972). A diferença principal nesta parte da sub-rotina de balanço de água no solo e o modelo de Ritchie é que a equação de PriestlyTaylor para estimativa da evapotranspiração potencial é usada em vez da equação de Penman. Assim não ha necessidade de inputs de pressão de vapor e vento, sendo necessário apenas dados de temperatura máxima e mínima e saldo de radiação, e sob muitas circunstâncias permite precisão igual. 
O cálculo da evaporação potencial requer uma aproximação de temperatura diária (TD) e o coeficiente de reflexão do solo-planta (ALBEDO) para radiação solar. Para a aproximação da temperatura diária são usados pesos significativos das temperaturas máxima (TEMPMX) e mínima (TEMPMN) diárias do ar. A evapotranspiração potencial e a disponibilidade de água governam a extração de água através da evaporação da camada superior do solo $(0-5 \mathrm{~cm})$ e da transpiração na zona radicular. A transpiração é proporcional à energia interceptada pelo dossel da cultura e a evaporação do solo depende da quantidade de energia que atinge a superfície do solo. Elas são afetadas pelo indice de área foliar, albedo do solo e umidade do solo. Em condições de baixo teor de água no solo, a absorção de água pelas raízes é reduzida, e consequentemente, a transpiração. Déficits hídricos determinam uma redução da fotossíntese e do crescimento em expansão e um aumento da partição da biomassa para as raízes (Faria et al., 1977).

\subsubsection{BALANÇO DE NITROGÊNIO}

As rotinas da dinâmica do nitrogênio dos modelos CERES segundo Godwin \& Jones (1991), foram designadas para simular cada um dos processos principais da perda de $\mathrm{N}$ e as contribuições para o balanço de $\mathrm{N}$ feito pela mineralização. As rotinas também descrevem a absorção de $\mathrm{N}$ pela cultura e os efeitos da deficiência de $\mathrm{N}$ nos processos de crescimento da cultura. As transformações simuladas são imobilização e/ou mineralização, nitrificação, denitrificação, e hidrólise da uréia. Movimento de nitrato associado com movimento de água em ambas as direções ascendente e descendente também é simulado. Como as taxas de transformação de nitrogênio são muito influenciadas pelo status da água no solo, a simulação da dinâmica do nitrogênio requer que o balanço de água também seja simulado. Temperaturas do solo influenciam extremamente muitas das taxas de transformação. Então, 
um procedimento para calcular temperatura de solo a várias profundidades, baseado na rotina de temperatura de solo do modelo ÉPIC (Williams et al. 1984), também é anexado ao componente de nitrogênio do modelo.

O modelo não simula perdas por volatilização de amônia ou balanço de troca de amônio e fixação. Sob condições de boas práticas de fertilizante onde fertilizante ou está incorporado ou colocado sob a superfície do solo, perdas de amônia por volatilização tendem a ser pequenas. Inputs descrevendo a quantidade de matéria orgânica e a quantidade de nitrogênio mineral presente no solo são exigidos para inicializar o modelo. O modelo requer a concentração de carbono orgânico em cada camada como um input e usa uma relação $\mathrm{C}: \mathrm{N}$ no solo assumida de 10:1 que calcula a quantidade de $\mathrm{N}$ orgânico associada ao material orgânico. Estas inicializações são executadas na sub-rotina SOILNI.

Para determinar a contribuição de resíduos de cultura recentes para o suprimento de nitrogênio no solo, o modelo exige também uma estimativa da quantidade de resíduo de cultura remanescente. Baseado nesta estimativa e na profundidade de incorporação do resíduo de cultura, o conteúdo de matéria orgânica fresca de cada camada é calculado. Uma estimativa da quantidade de resíduo de raiz que permanece da cultura antecedente também é requerida para os cálculos do balanço de nitrogênio. Assim são estimadas as absorções de nitrato $\left(\mathrm{NO}_{3}{ }^{-}\right)$e amônia $\left(\mathrm{NH}_{4}{ }^{+}\right)$pela planta, as quais dependem de suas concentrações no solo, da disponibilidade de água e da densidade de raízes em cada camada do solo. A demanda diária de $\mathrm{N}$ pela cultura é calculada a partir do acúmulo de matéria seca em cada órgão da planta multiplicada pela concentração máxima de $\mathrm{N}$ encontrada nos tecidos do milho, cujos valores são definidos no arquivo de espécie (MZCER*.SPE).

\subsection{DADOS REQUERIDOS (INPUTS) E SAIDAS (OUTPUTS) DO MODELO}

O modelo necessita de vários grupos de dados de entrada (inputs) relati- 
vos aos parâmetros fisico-hídricos do solo, genética da planta, elementos do clima e informações do manejo da cultura. Na tabela 3.2 é apresentado um resumo das principais variáveis requeridas pelo modelo CERES-maize.

Tabela 3.2. Dados do perfil do solo, elementos do clima, parâmetros genéticos da cultivar e características do manejo da cultura, necessários para a simulação com o modelo CERES-Maize.

\begin{tabular}{ll}
\hline & Parâmetros do solo \\
\hline 1 & Albedo do solo \\
2 & Coeficiente de drenagem no perfil do solo \\
3 & Número da curva de escoamento superficial \\
4 & Espessura das camadas do perfil do solo \\
5 & Umidade de saturação de cada camada \\
6 & Fator de ponderação da distribuição radicular \\
7 & Densidade global e textura do solo \\
8 & Limite inferior de água disponível de cada camada \\
9 & Limite superior de água disponivel de cada camada \\
\hline & Coeficientes genéticos da cultivar \\
\hline 1 & Soma térmica da emergência até o final do período juvenil \\
2 & Coeficiente de sensibilidade ao fotoperíodo \\
3 & Soma térmica do período florescimento à maturação fisiológica \\
4 & Número potencial de sementes por planta \\
5 & Taxa potencial de crescimento de semente \\
\hline & Elementos do clima \\
\hline 1 & Radiação solar ou insolação \\
2 & Chuva \\
3 & Temperatura máxima \\
4 & Temperatura mínima \\
5 & Coordenadas geográficas \\
\hline & Informações do manejo \\
\hline 1 & Nome da cultivar \\
2 & Dados da área de plantio \\
3 & Dados de análise físico-química do solo \\
5 & Dados sobre o plantio \\
6 & Irrigação \\
7 & Rertilizantes \\
\hline
\end{tabular}


No caso de estudos com análise econômicas de estratégias de manejo, informações de preços e custos de produtos e insumos também são necessárias. Estes dados são fornecidos em arquivos apropriados, cujos formatos são padronizados (IBSNAT,1990), que são lidos pelo modelo por ocasiāo das simulações. Os resultados das simulações, em intervalos selecionados pelo usuário, são reunidos em vários arquivos de saídas relativos à aspectos do crescimento sazonal da planta e sua fenologia, balanço de água e nitrogênio do solo, e informações sumarias do rendimento, evapotranspiração e irrigação, os quais também apresentam um formato padronizado (IBSNAT, 1990).

\subsection{SIMULAÇÕES NA SUBROTINA "SEASONAL"}

As simulações foram realizadas na sub-rotina "seasonal" do DSSAT 3.5, a qual permite a análise de longo período a partir de registros das variáveis meteorológicas e informações de manejo de uma determinada cultivar especifica em um dado local (solo). Permite a comparação de simulações com diferentes combinações de entradas. Simulações de experimentos com muitos tratamentos podem ser repetidos em vários anos, obtendo suas funções de probabilidade acumulada, que permite selecionar os tratamentos mais eficientes.

A análise seasonal pode ser usada para comparação de métodos de manejo de culturas em um ambiente particular, tal como diferentes datas de semeadura, variedades, níveis de adubação e manejo da irrigação.

Se tais comparações são feitas através de muitos anos com condições de clima diferentes, então a variabilidade associada com a performance da cultura, como uma função de interaçōes entre clima e outros fatores do ambiente físico, pode ser isolado e quantificado.

Existem 3 passos básicos envolvidos na análise seasonal, que são:

1. A criação de um arquivo de entradas (inputs) apropriado ao modelo;

2. Processamento do modelo usando um programa especial de controle 
chamado "análise seasonal";

3. Analise dos resultados das simulações usando o programa de Análise Seasonal.

A Figura 3.2 ilustra estes passos e os arquivos e programas envolvidos na análise seasonal.

O programa Xcreate (Immamura, 1994) pode ser usado para criar os arquivos de entrada (FILEXs) com as informações dos experimentos para o modelo rodar as análises seasonal. Poderá ser usado também um editor de texto (ASCII) apropriado para a criação destes arquivos. Os experimentos são então simulados com as repetições especificadas neste arquivo.

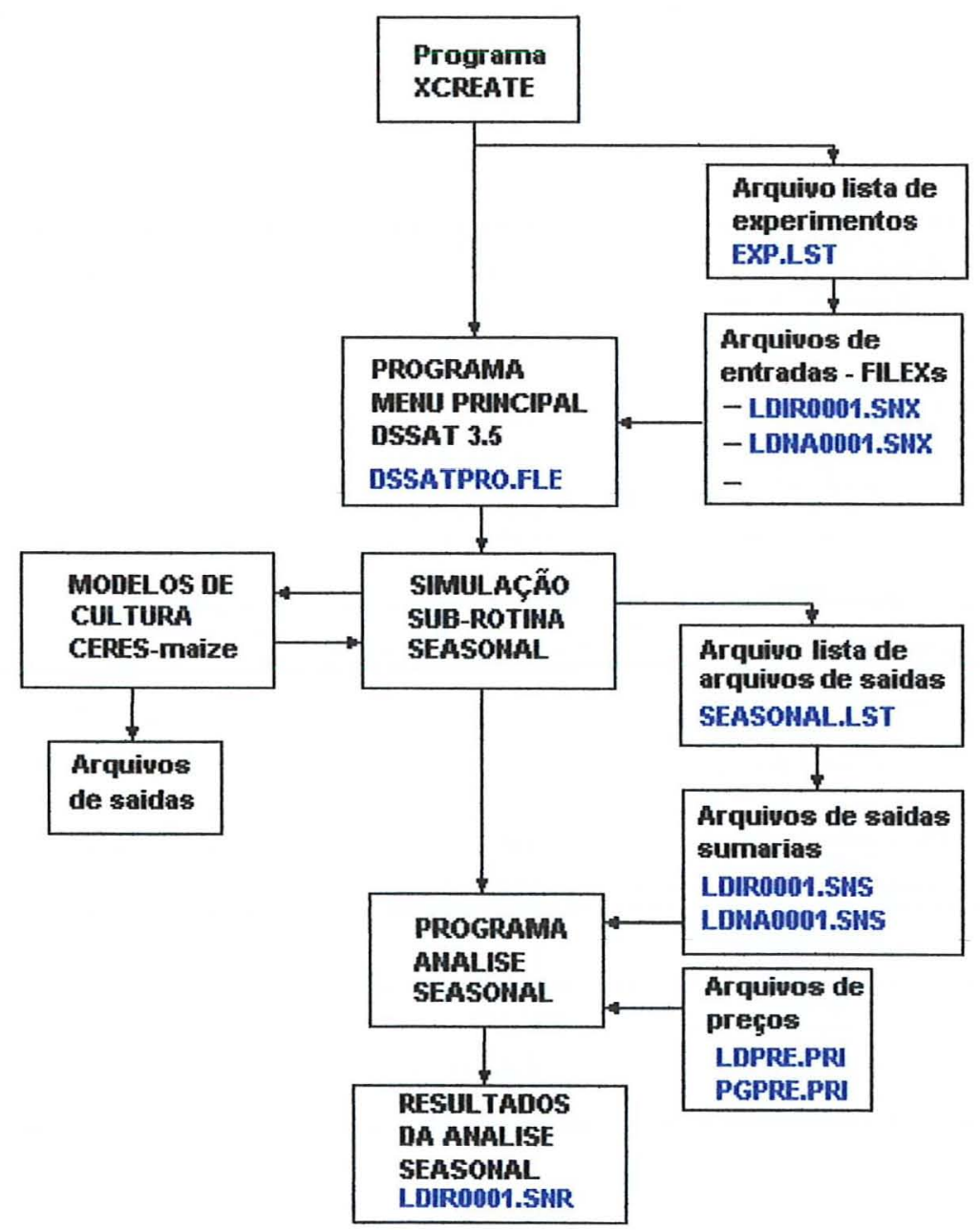

Figura 3.2. Esquema simplificado dos passos para a Análise Seasonal no DSSAT 3.5 
Para o processamento das simulações na opção análise seasonal, o arquivo de entrada (FILEX) criado pelo usuário é lido pelo modelo de cultura.

Uma vez produzido o arquivo de saídas resumidas das simulações de um experimento seasonal, pode-se efetuar a análise deste ou comparar seus tratamentos. Nesta análise o modelo calcula médias, desvios padrão, máximos e mínimos para 35 variáveis do arquivo de saídas resumidas. Além destes, também podem ser obtidos os gráficos das análises Média-variância, e Funções de probabilidade cumulativas, que permitem definir as estratégias mais eficientes pela análise da dominância estocástica em $1^{\circ}$ ou $2^{\circ}$ grau e médiaGini. Os resultados desta análise são armazenados em arquivos apropriados.

\subsection{LOCAL DE ESTUDO}

As simulações foram feitas para duas localidades do Estado do Paraná: Londrina (Latitude: $23^{\circ} 22^{\prime}$; Longitude: $51^{\circ} 10^{\prime}$; Altitude: $585 \mathrm{~m}$ ) e Ponta Grossa (Latitude: $25^{\circ} 06^{\prime}$; Longitude: $50^{\circ} 10^{\prime}$; Altitude: $880 \mathrm{~m}$ ) que estão indicadas na Figura 3.3.

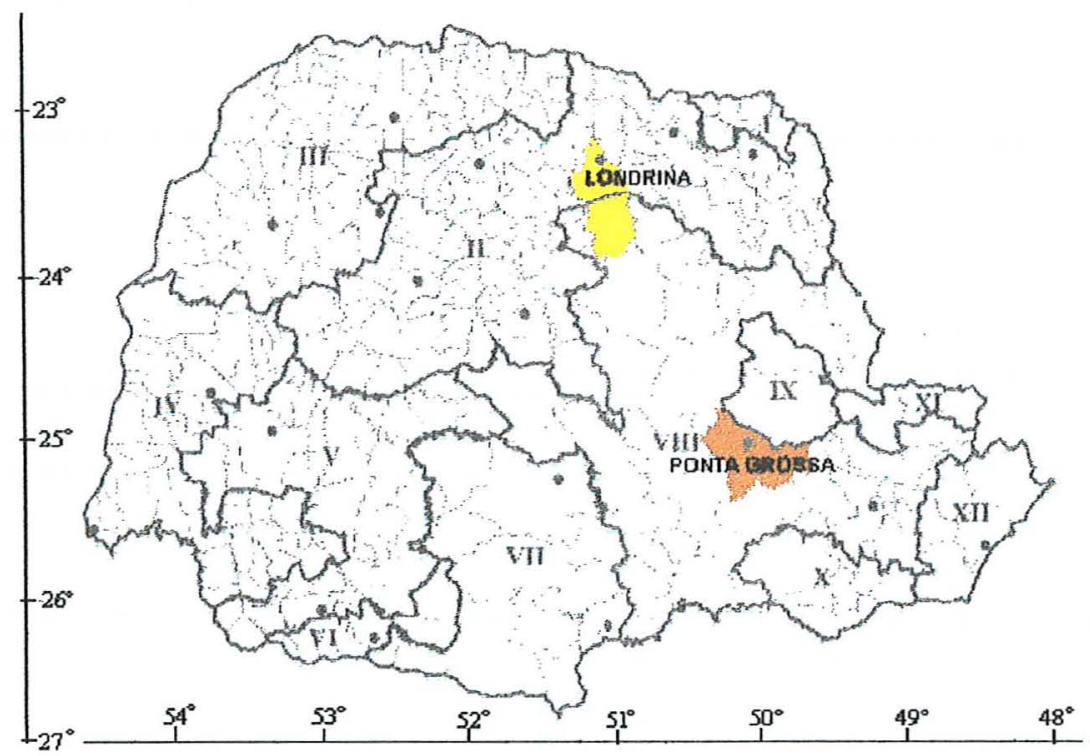

Figura 3.3. Regionalização do milho para o Paraná e locais das simulações 
Nestas regiōes, o clima é subtropical úmido, caracterizado por verão quente e inverno fresco com pouca chuva e geadas ocasionais de junho a agosto. Aproximadamente dois-terços dos 1200 a $1900 \mathrm{~mm}$ precipitados anualmente ocorrem nas estações primavera-verão, de outubro a março.

Os valores médios das principais variáveis meteorológicas, para Londrina e Ponta grossa, obtidas a partir da série histórica de 1976 a 1999, são listados na tabela 3.3. a seguir.

Tabela 3.3. Dados meteorológicos (médias) para Londrina e Ponta Grossa no período de1976 a1999.

\begin{tabular}{|c|c|c|c|c|c|}
\hline Variável & $\begin{array}{l}\text { Radiação } \\
\left(\text { MJ.m }^{-2}\right)\end{array}$ & $\begin{array}{l}\text { Tmax } \\
\left({ }^{\circ} \mathrm{C}\right)\end{array}$ & $\begin{array}{l}\text { Tmin } \\
\left({ }^{\circ} \mathrm{C}\right)\end{array}$ & $\begin{array}{l}\text { Chuva } \\
\text { (mm) }\end{array}$ & $\begin{array}{c}\text { Dias c/ chuva } \\
\text { (dias) }\end{array}$ \\
\hline Mês & \multicolumn{5}{|c|}{ LONDRINA } \\
\hline Janeiro & 21.0 & 29.5 & 19.5 & 203.2 & 15.1 \\
\hline Fevereiro & 20.4 & 29.6 & 19.4 & 180.1 & 14.2 \\
\hline Março & 19.2 & 29.3 & 18.5 & 141.4 & 11.6 \\
\hline Abril & 17.7 & 27.6 & 16.4 & 119.5 & 8.7 \\
\hline Maio & 14.2 & 24.6 & 13.7 & 115.6 & 9.0 \\
\hline Junho & 12.9 & 22.8 & 11.7 & 105.5 & 8.9 \\
\hline Julho & 14.5 & 23.5 & 11.5 & 56.2 & 6.1 \\
\hline Agosto & 16.5 & 25.5 & 12.8 & 50.3 & 5.9 \\
\hline Setembro & 17.1 & 26.1 & 14.3 & 123.1 & 9.2 \\
\hline Outubro & 20.6 & 28.5 & 16.5 & 135.9 & 10.2 \\
\hline Novembro & 22.4 & 29.4 & 18.0 & 174.7 & 11.2 \\
\hline Dezembro & 21.3 & 29.2 & 19.0 & 217.9 & 14.4 \\
\hline \multirow{2}{*}{ Média/soma* } & 18.2 & 27.1 & 15.9 & $1623.4^{\star}$ & $124.5^{\star}$ \\
\hline & \multicolumn{5}{|c|}{ PONTA GROSSA } \\
\hline Janeiro & 19.1 & 27.3 & 17.5 & 184.9 & 16.4 \\
\hline Fevereiro & 18.3 & 27.1 & 17.6 & 137.2 & 15.2 \\
\hline Março & 17.0 & 26.2 & 16.5 & 137.4 & 13.7 \\
\hline Abril & 14.9 & 24.1 & 14.4 & 102.7 & 9.0 \\
\hline Maio & 12.4 & 21.3 & 11.5 & 147.7 & 9.8 \\
\hline Junho & 11.2 & 19.7 & 9.8 & 109.5 & 8.7 \\
\hline Julho & 12.3 & 19.9 & 9.7 & 109.1 & 8.0 \\
\hline Agosto & 14.3 & 21.3 & 10.6 & 77.7 & 7.5 \\
\hline Setembro & 15.4 & 21.8 & 11.7 & 136.4 & 10.7 \\
\hline Outubro & 17.9 & 24.2 & 13.8 & 149.2 & 12.2 \\
\hline Novembro & 19.7 & 26.0 & 15.4 & 136.1 & 12.1 \\
\hline Dezembro & 19.2 & 26.8 & 16.7 & 155.6 & 13.4 \\
\hline Média/soma* & 16.0 & 23.8 & 13.8 & $1583.5^{*}$ & $136.7^{*}$ \\
\hline
\end{tabular}


A disponibilidade média de radiação solar é notoriamente maior em Londrina do que em Ponta Grossa, o que pode resultar em diferentes níveis de produtividade do milho nestes locais. Esta diferença também ocasiona maiores valores médios de temperatura máxima e mínima em Londrina.

Quanto às precipitações, observa-se que em Londrina o volume total de chuva é maior do que em Ponta Grossa. A distribuição de chuvas também é diferente nos dois locais, sendo mais elevada em Londrina nos meses de novembro a abril e menor nos demais meses doa ano. Além disso, o número de dias chuvosos é maior em Ponta Grossa, exceto nos meses de junho e dezembro.

Um estudo feito por Grodzki et al. (1996), caracterizou a ocorrência de geadas no Estado do Paraná, sendo um fenômeno bastante frequente principalmente durante o outono-inverno, causando graves consequências para a agricultura. A Figura 3.4. obtida daquele estudo mostra que os meses com maior ocorrência de geadas foram junho (Ponta Grossa) e julho (Londrina). Nos meses de maior ocorrência, Ponta Grossa apresenta aproximadamente quatro geadas por ano (40 em 10 anos), enquanto que em Londrina esse valor não chega a uma por ano (menos que 10 em 10 anos). Observou-se também que o período de ocorrência de geadas estende-se desde abril até novembro em Ponta Grossa e desde maio a setembro em Londrina.

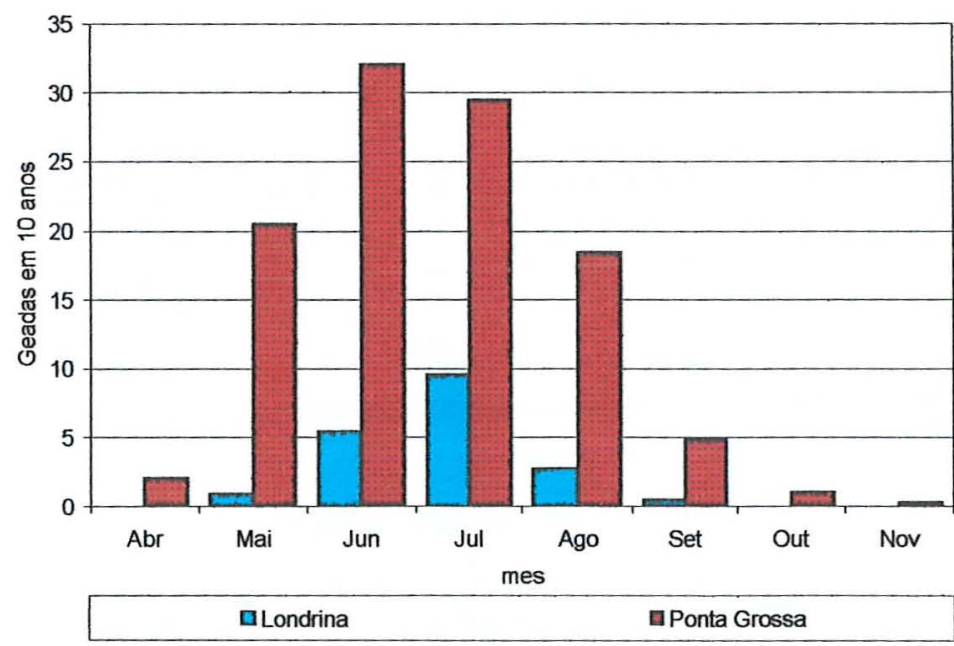

Figura 3.4. Ocorrência média de geadas em 10 anos, por mês e local, no Estado do Paraná (Grodzki et al. 1996) 


\subsection{INFORMAÇÕES GERAIS}

Os dados de registros meteorológicos foram obtidos das estações meteorológicas do IAPAR, cujas séries históricas de registros contém 24 anos de extensão (1976-1999) em Londrina e em Ponta Grossa. Consistem em registros diários de radiação solar, chuva, temperaturas máximas e mínimas. A partir destas informações, o próprio modelo efetua estimativas diárias de Evapotranspiração da cultura em questão.

Os dados de solos (características físico-hídricas) foram obtidos de ensaios experimentais conduzidos por pesquisadores do IAPAR nos solos representativos de cada local e cujos valores são apresentados no anexo 1 e 2.

Em Londrina o solo predominante foi classificado como sendo um Latossolo Roxo (Typic Haplorthox), caracterizado por conteúdos de argila de 40 a $60 \%$, perfis profundos, alta infiltração, nivel de água freática ausente ou profundo, e baixo conteúdo de matéria orgânica, menor que 3\% (Faria et al., 1997).

Para Ponta Grossa o solo predominante foi classificado como sendo um Latossolo Vermelho Escuro (textura média), caracterizado por perfis profundos, alta infiltração, nivel de água freática ausente ou profundo, e baixo conteúdo de matéria orgânica, menor que 3\% (Faria et al., 1997).

\subsection{DADOS RELATIVOS AO MANEJO}

As condições de manejo para o milho "safrinha", nos distintos cenários de simulação, sem irrigação (sob chuva atual) e sob irrigação a partir de certos níveis de água disponível no solo, seguem as recomendações técnicas gerais sugeridas no Programa Milho do IAPAR, que são listadas a seguir :

O período de semeadura para o milho safrinha adotado neste estudo abrangem os meses de janeiro à maio, subdividido em 15 decêndios, que correspondem às épocas de plantio. Assim, foram feitas simulações para dife- 
rentes datas de semeadura, uma em cada decêndio, que foram considerados como tratamentos. No cenário sem irrigação o plantio só era realizado no decêndio em que certas condições fossem verificadas. As condições necessárias para o estabelecimento do cultivo, fornecidas como inputs ao modelo, foram: umidade do solo superior a $50 \%$ da água disponível (AD) nos primeiros $10 \mathrm{~cm}$ de profundidade do solo e temperatura do solo entre 10 a $40^{\circ} \mathrm{C}$, nesta camada.

Considerou-se um espaçamento de $0,9 \mathrm{~m}$ entre linhas com $6,0 \mathrm{pl} . \mathrm{m}^{-2}$, que corresponde a 66.667 pl.ha $^{-1}$ e com aplicações de nitrogênio nas doses de $20 \mathrm{~kg} \cdot \mathrm{ha}^{-1}$ na semeadura e $50 \mathrm{~kg} \cdot \mathrm{ha}^{-1}$ em cobertura 45 a 50 dias após plantio. Considerou-se ainda a incorporação dos resíduos da cultura antecedente. $O$ anexo 2 apresenta um exemplo de arquivo $X$ com seus respectivos inputs de manejo para as datas de semeadura pré determinadas.

\subsection{CALIBRAÇÃO DOS COEFICIENTES GENÉTICOS}

A calibração do modelo consiste em ajustes feitos nos parâmetros e entradas (inputs) do modelo visando minimizar os desvios entre os dados simulados e os observados no campo (experimentos) para várias situações $\theta$ locais, ou seja, com a calibração busca-se que valores simulados se aproximem ao máximo dos valores medidos no campo, alterando criteriosamente os inputs.

Os coeficientes genéticos para a cultivar XL-520 do tipo precoce foram obtidos de um estudo de calibração segundo Lima (1995) e cujos dados estão resumidos no anexo 3 .

A cultivar XL-520 consta das recomendações de cultivares para o estado do Paraná, sendo classificada dentro do grupo que necessita entre 780 e 860 unidades de calor no período entre a emergência e seu florescimento.

O uso dos coeficientes genéticos obtidos em um outro local e não no local do estudo, pode ser justificado por serem estes inerentes a própria cultivar, sendo que uma vez obtidos com sucesso, estes podem serem usados 
em outros locais, principalmente naqueles cujas as condições de ambiente sejam semelhantes.

Fez-se, então, uma simulação prévia, com estes coeficientes e dados de clima e solo observados em Londrina, para verificar se os resultados simulados apresentavam-se realisticamente. Comparando-se os resultados simulados com os obtidos nos experimentos da "avaliação estadual de cultivares de milho safrinha", (Gerage et al., 1997 e 1998), observou-se (Tabela 3.4) boa similaridade quanto a aspectos fenológicos e de rendimento. Possivelmente o modelo tenha superestimado os valores de rendimento, o que era de se esperar, já que o mesmo não considera algumas reduções aleatórias de rendimento devido à doenças, pragas e eventos catastróficos.

Tabela 3.4. Comparação entre dados simulados e experimentos da avaliação estadual de cultivares de milho safrinha em Londrina.

\begin{tabular}{|c|c|c|c|c|c|c|}
\hline \multirow{2}{*}{ ano } & \multicolumn{2}{|c|}{ Semeadura-antese (dias) } & \multicolumn{2}{c|}{ Ciclo (dias) } & \multicolumn{2}{c|}{ Rendimento (kg.ha $^{-1}$ ) } \\
\cline { 2 - 7 } & Simulado & Observado & Simulado & Observado & Simulado & Observado \\
\hline 1997 & 79 & 68 a 78 & 169 & 187 & 4890 & 3660 a 5650 \\
\hline 1998 & 66 & 59 a 67 & 157 & 149 & 8215 & 2890 a 8420 \\
\hline
\end{tabular}

\subsection{CONSIDERAÇÕES GERAIS RELATIVAS ÀS SIMULAÇÕES}

As simulações foram processadas considerando-se três cenários, um para produção potencial, um sem irrigação (condição de chuva atual) e outro sob irrigação (abrangendo as diferentes estratégias a serem analisadas).

Para o cenário sem irrigação e de produção potencial, as simulações em todos os anos da série histórica começaram 60 dias antes do inicio de cada decêndio da respectiva época de semeadura fixada. As condiçōes iniciais de umidade do solo, no início de cada simulação foram consideradas em $50 \%$ da capacidade de água disponível do solo em todas as camadas do perfil do solo. 
Para o cenário sob irrigação as simulações tiveram início nas datas de semeadura obtidas no cenário sem irrigação, ou seja, nas mesmas datas onde as condições necessárias para o estabelecimento da cultura estavam disponíveis em cada decêndio. Nos decêndios onde ocorreram falhas no estabelecimento da cultura no cenário sem irrigação, que decorrem principalmente da escassez de chuva, a semeadura no cenário sob irrigação realizou-se no ultimo dia do decêndio, assumindo que a umidade fosse igual a $100 \%$ de água disponível $(A D)$ do solo, proporcionado pela irrigação efetuada antes da semeadura. Essa suposição baseia-se no fato de que a umidade do solo é o principal fator que influi no estabelecimento da cultura, e o agricultor espera até o penúltimo dia do decêndio, se não ocorreu chuva suficiente para abastecer adequadamente o solo ele então irriga o solo até $100 \%$ de $A D$ e faz a semeadura no dia seguinte.

Foi realizado um teste de sensibilidade para detectar os efeitos do clima nas simulações efetuadas pelo modelo alvo do estudo, assumindo valores afastados em $20 \%$ dos valores meteorológicos reais observados, e para verificar se o modelo foi calibrado adequadamente. Estabeleceu-se como critério para emergência o valor crítico de umidade do solo de $50 \%$ da água disponível na profundidade $0-10 \mathrm{~cm}$ e temperatura do solo entre 10 e $40^{\circ} \mathrm{C}$ nesta camada.

\subsection{ESTRATÉGIAS DE IRRIGAÇÃO}

As estratégias de irrigação do cenário de manejo da irrigação, consistiram em variações da água do solo (Níveis críticos de água no solo para iniciar a irrigação entre 10 a $90 \%$ da água disponível (AD) no solo, em intervalos de $20 \%$, totalizando 5 niveis) na profundidade de $30 \mathrm{~cm}$, além de um nível sem irrigação, que constituirão os tratamentos nas simulações, para cada data de semeadura. Nos tratamentos com irrigação considerou-se que a água era aplicada de forma instantânea e uniforme por um sistema de pivô-central e que 
a água de irrigação não representava um recurso limitante. Estas estratégias foram analisadas a partir de critérios, descritos a seguir:

$-1^{\circ}$ critério: Baseou-se no máximo rendimento físico;

- $2^{\circ}$ critério: Baseou-se no lucro máximo, que é definido como o valor total da produção menos os custos, ou seja na maximização da receita e minimização dos custos;

- $3^{\circ}$ critério: Baseou-se na minimização dos riscos econômicos para o agricultor, analisados pela dominância estocástica das funções de probabilidade.

\subsection{ANÁLISE ECONÔMICA}

Os dados referentes a preço de insumos e do produto foram obtidos nas publicações da Companhia nacional de abastecimento (CONAB), da Secretaria de Agricultura do Paraná e do Instituto Agronômico do Paraná (IAPAR) além de outras publicações (Agrianual) disponíveis na literatura. A partir destes dados, procedeu-se a análise econômica, assumindo um preço médio fixo e posteriormente procedeu-se uma análise de sensibilidade, variando este valor em $20 \%$.

$\mathrm{Na}$ análise econômica, para a otimização do lucro líquido a função objetivo pode ser definida como:

Renda líquida $a_{(\mathrm{i}, \mathrm{d})}=$ renda bruta $a_{(\mathrm{i}, \mathrm{d})}$ - custo básico de produção $\mathrm{i}_{(\mathrm{i}, \mathrm{d})}$ - custo variável da irrigação(i,d) - custo fixo da irrigação $(i, d)$.

onde, i é o índice das diferentes estratégias de irrigação e d é o índice do decêndio em que realizou-se a semeadura.

Os valores de renda bruta em cada estratégia $\left(R \$ . h a^{-1}\right)$ foram obtidos pelo produto da produtividade $\left(\mathrm{kg} \cdot \mathrm{ha}^{-1}\right)$ e o preço unitário do produto $\left(\mathrm{R} \$ . \mathrm{kg}^{-1}\right)$. O preço unitário segundo Nicoletti (1997), AGRIANUAL (1999) e CONAB (2000), apresentou os seguintes valores no período de 1993 a 1999: valor 
médio igual a $R \$ 8,21$ por saca de $60 \mathrm{~kg}$; valor mínimo igual a $R \$ 6,56 \mathrm{saca}^{-1} \mathrm{e}$ valor máximo igual a $\mathrm{R} \$ 11,15 \mathrm{saca}^{-1}$; Estes valores são correspondentes em reais de dezembro de 1999 deflacionados com o índice geral de preços (IGP) da fundação Getúlio Vargas.

O custo básico de produção ( $\mathrm{Cbp}$ ) foi considerado como um valor constante independente do aumento da produção decorrente da estratégia implementada. Segundo AGRIANUAL (1999), o valor médio de custo básico de produção para o milho safrinha é igual a $R \$ 355,00 \mathrm{ha}^{-1}$.

Para o custo variável da irrigação considerou-se uma variação linear obtida pelo produto da lâmina de irrigação e um valor unitário constante $\left(\mathrm{R} \$ \mathrm{~mm}^{-1}\right)$ acrescido pelos custos operacionais para cada aplicação da irrigação. Adotou-se o valor de $\mathrm{R} \$ 0,50 \mathrm{~mm}^{-1}$ (IPT, 1994) que foi obtido de uma média de vários projetos de irrigação com pivô-central.

Os custos fixos da irrigação incluíram os valores da depreciação para uma vida útil de 10 anos e juros de capital de $12 \%$ ao ano, totalizando um valor de $R \$ 145,00$ ha $^{-1}$ (Frizzone et al., 1994), assumido sendo os custos médios para áreas irrigadas com pivô-central.

As médias e desvios das rendas líquidas bem como suas funções de probabilidade acumulada foram então calculadas e usadas para resumir e comparar as estratégias.

\subsection{TESTE DE SENSIBILIDADE}

Foram realizados testes de sensibilidade para detectar os efeitos dos parâmetros de clima nas simulações efetuadas pelo modelo alvo do estudo, assumindo valores afastados em $-20 \%$ e $+20 \%$ dos valores médios adotados para verificar se o modelo apresentava resposta realística. Fez-se também uma análise de sensibilidade em relação aos aspectos econômicos mediante a variação dos preços e custos médios assumidos nos cenários de simulação. 


\subsection{ANÁLISE ESTATÍSTICA}

As funções de probabilidade cumulativa são obtidas ordenando a série dos valores da variável em estudo em ordem crescente e relacionando-os com probabilidades cumulativas em intervalos equidistantes. Neste caso pode-se utilizar a expressão para o calculo da probabilidade cumulativa $(P)$, tal como,

$$
P=\frac{m}{N+1}
$$

onde, $\mathrm{m}$ é o número de ordem do valor da variável aleatória na série ordenada em ordem crescente e $\mathrm{N}$ é o número de observações ou valores da série analisada.

Conhecida as funções de probabilidade da variável em estudo pode-se obter seus valores esperados para vários quantis. No DSSAT são obtidos os valores esperados relativos aos percentis $0,25,50,75$ e $100 \%$. O percentil $50 \%$ corresponde ao valor da mediana da distribuição da variável em estudo, que no caso de uma distribuição simétrica geralmente seu valor é igual a média dos valores da amostra.

\subsection{ANÁLISE DE VARIÂNCIA}

Utilizou-se para efetuar a análise de variância o aplicativo SW NTIA EMBRAPA-CNTIA (1997) v.4.2.2, considerando um nível de significância de $5 \%$ de probabilidade. $\mathrm{Na}$ comparação dos contrastes entre dois tratamentos utilizou-se o teste de TUKEY e o teste de DUNNETT foi usado para comparar os tratamentos de irrigação com o tratamento testemunha (sem irrigação). 


\section{RESULTADOS E DISCUSSÃO}

\subsection{SIMULAÇÕES PARA O CENÁRIO DE PRODUÇÃO POTENCIAL}

No cenário de produção potencial, o modelo assume que água e nitrogênio não são limitantes, ou seja, a produção potencial fica condicionada principalmente aos elementos climáticos, tais como: radiação solar e temperatura. Assim, podemos verificar a influência do clima sobre a duração dos estádios fenológicos e sobre o rendimento potencial do milho "safrinha" decorrente da época de semeadura implementada.

\subsubsection{ASPÉCTOS FENOLÓGICOS DA PRODUÇÃO POTENCIAL.}

Na Figura 4.1 observa-se que as durações médias do período semeadura à antese tenderam a aumentar a medida que a semeadura foi mais tardia, apresentando uma variação mais pronunciada em Ponta Grossa do que em Londrina, isto pode ser atribuido ao fato de que este estádio do ciclo da cultura do milho "safrinha" vai confrontado-se com temperaturas cada vez mais baixas, necessitando mais tempo para acumular o número de unidades térmicas (graus-dia) necessárias para completar este estádio do ciclo. Na tabela 4.1 são apresentados os valores mínimos, máximos e médios das durações do estádio semeadura à antese e do ciclo total obtidos nas simulações.

As durações médias deste estádio são maiores em Ponta Grossa devido 

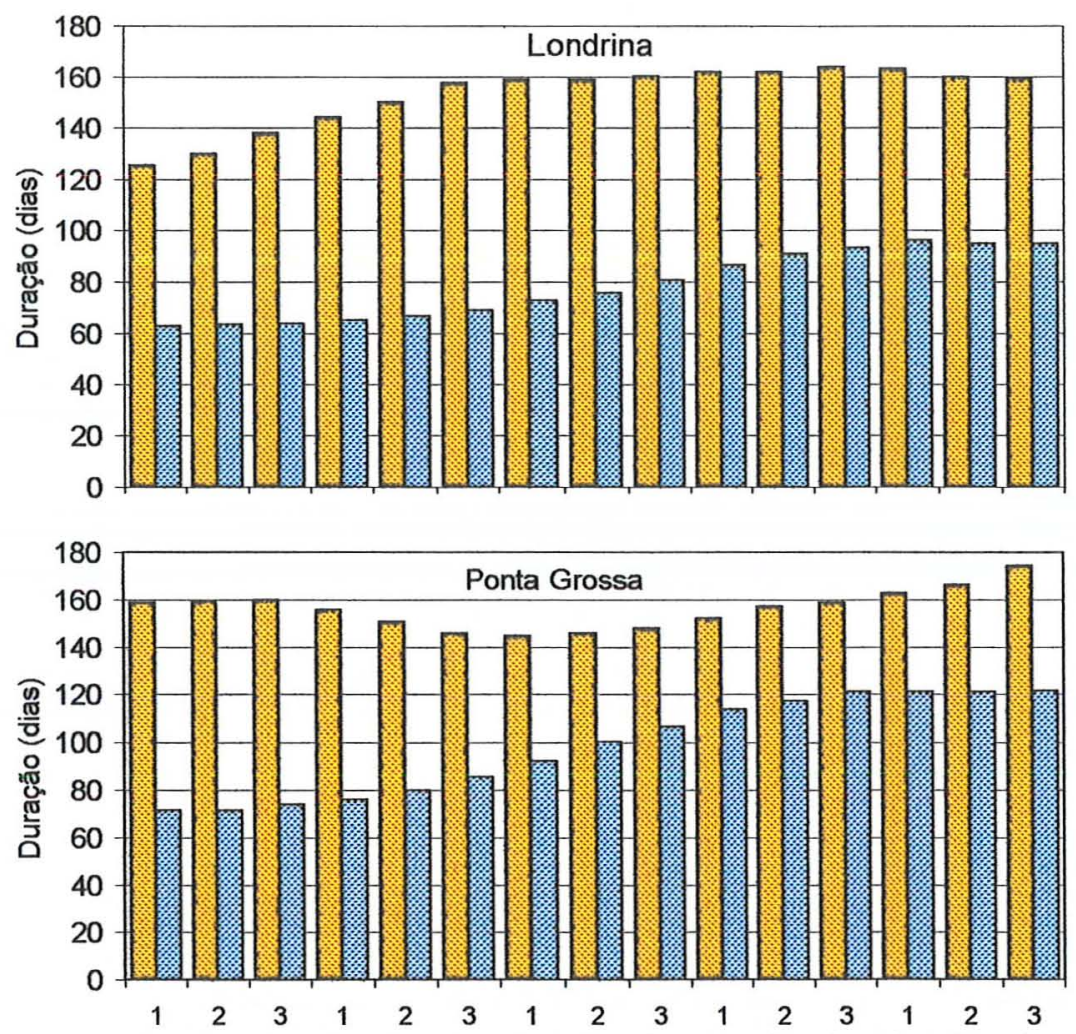

dec. dec. dec. dec. dec. dec. dec. dec. dec. dec. dec. dec. dec. dec. dec. jan. jan. jan. fev. fev. fev. mar. mar. mar. abr. abr. abr. mai. mai. mai.

Semeadura

Figura 4.1. Durações médias da semeadura à antese e do ciclo do milho "safrinha" em semeaduras no período de janeiro a maio para Londrina e Ponta Grossa, no cenário de produção potencial.

apresentar temperaturas mais amenas do que em Londrina, fazendo com que a cultura fique mais tempo exposta às condições de estresses, sendo que condições ambientais adversas, ocorridas entre o florescimento e a maturação fisiológica, determinam a finalização abrupta do período de enchimento de grão devido ao lento enchimento dos mesmos, decorrente das baixas taxas de crescimento que são altamente influenciadas pelas temperaturas baixas. Em Londrina a duração média do estádio semeadura à antese passou de 63 dias nas semeaduras do início de janeiro para 96 dias nas semeaduras dos primeiros decêndios de maio, já em Ponta Grossa esta variação foi de 71 dias para122 dias neste mesmo período. 
Tabela 4.1. Valores mínimos, máximos e médios das durações do estádio semeadura à antese e do ciclo total obtidos nas simulações, para Londrina e Ponta Grossa, no cenário de produção potencial.

\begin{tabular}{|c|c|c|c|c|c|c|}
\hline \multirow{2}{*}{ Local } & \multicolumn{3}{|c|}{ Semeadura-antese (dias) } & \multicolumn{3}{c|}{ Ciclo (dias) } \\
\cline { 2 - 7 } & mínimo & Médio & Máximo & Mínimo & Médio & Máximo \\
\hline Londrina & 56 & 80 & 109 & $117\left(97^{*}\right)$ & 153 & 187 \\
\hline Ponta Grossa & 65 & 101 & 141 & $129\left(101^{*}\right)$ & 160 & 219 \\
\hline
\end{tabular}

${ }^{*}$ Valores de ciclos finalizados antes do tempo normal devido ao lento enchimento de grão.

Para Londrina a duração média do ciclo que no início de janeiro era de 125 dias tendeu a aumentar quando se atrasou a semeadura até março passando a 160 dias, tendendo a decrescer para semeaduras a partir do mês de maio, evidenciando a influência de temperaturas baixas em alongar o ciclo total da cultura. Esta tendência não se verificou em Ponta Grossa pois em muitos anos os ciclos foram interrompidos antecipadamente durante o enchimento de grãos devido à condições adversas (temperaturas baixas e déficits hídricos), principalmente para semeaduras após o $2^{\circ}$ decêndio de fevereiro (Figura 4.2), sendo que na semeadura do $1^{\circ}$ decêndio de abril ocorreram 19 safras com ciclo interrompido em 24 anos de simulação $(79,2 \%)$, o que resultou em prejuízos nas análises dos aspectos fenológicos como também dos rendimento.

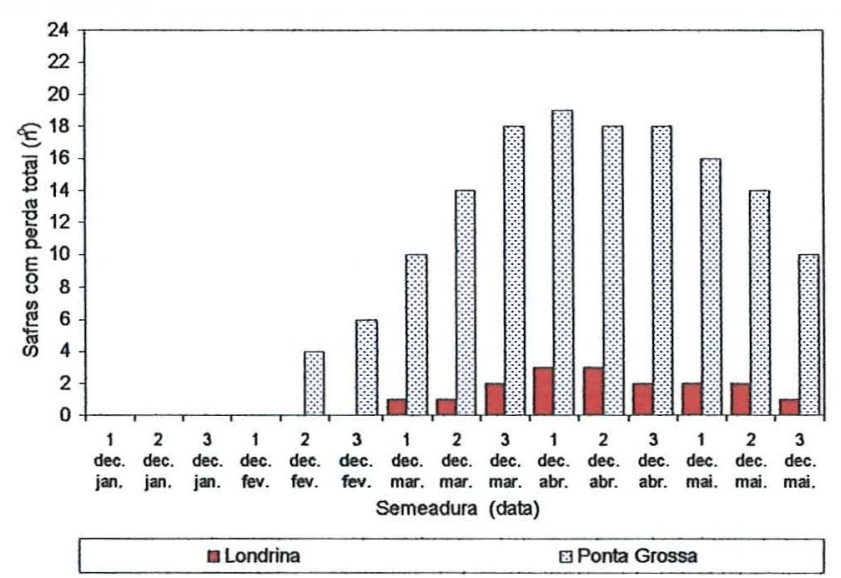

Figura 4.2. Número de safras com perda total de grãos e ciclo interrompido antecipadamente em 24 anos de simulações para Londrina e Ponta Grossa, no cenário de produção potencial. 
Em Londrina o número de ciclos afetados drasticamente por temperaturas baixas foi bem menor, ocorrendo nas semeaduras a partir do $1^{\circ}$ decêndio de março, sendo a maior freqüência nas semeaduras do $1^{\circ}$ e $2^{\circ}$ decêndios de abril com 3 safras prejudicadas em 24 anos de simulação (12,5\%). O modelo nestas situações finaliza abruptamente o enchimento de grãos, devido ao lento enchimento dos mesmos, e interrompe o ciclo da cultura antecipadamente. Então os valores médios de duração dos ciclos obtidos nestes decêndios foram menores do que seriam se a cultura completasse seu ciclo adequadamente.

Estes valores demonstram que o modelo foi sensível quanto a resposta às variações de temperatura sobre a duração dos estádios e ciclo da cultura do milho "safrinha", o que ficou mais evidente na análise de sensibilidade.

$\mathrm{Na}$ análise de sensibilidade (Figura 4.3, 4.4 e 4.5), reduções de $20 \%$ nos
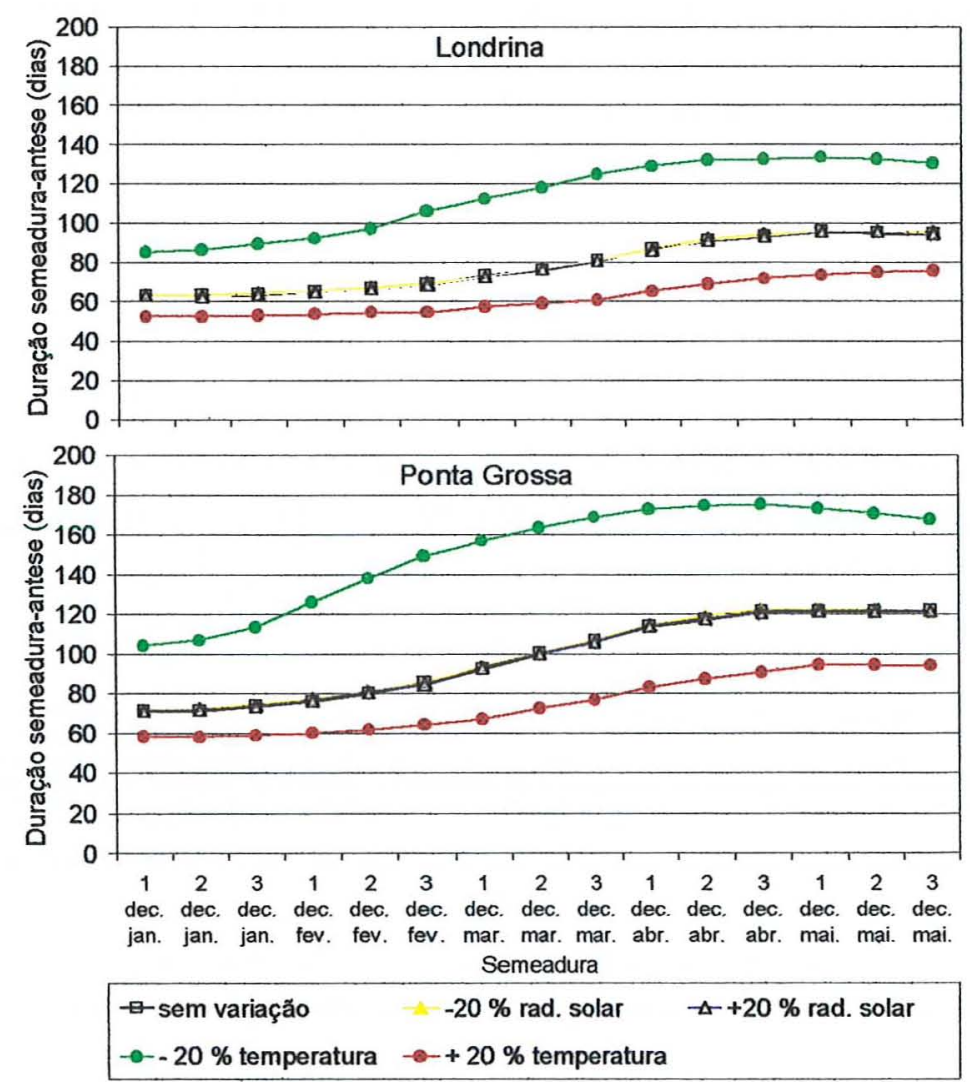

Figura 4.3. Durações médias da semeadura à antese do milho "safrinha" devido à variações de radiação solar e temperatura em semeaduras no período de janeiro a maio para Londrina e Ponta Grossa no cenário de produção potencial. 
valores de temperatura promoveram um alongamento médio na duração do estádio semeadura à antese e do ciclo total em torno de 43,5 e 40,1\% em Londrina, e em Ponta Grossa esta variação foi de 51,6 e 37,0\%, respectivamente. Quando os valores de temperatura foram aumentados em 20\% verificou-se reduções médias na duração do estádio semeadura à antese e do ciclo total em torno de 20,9 e 22,4\% em Londrina, e de 23,2 e $20,5 \%$ em Ponta Grossa, respectivamente.

O modelo, mostrou-se pouco sensível às variações (+20\% e $-20 \%)$ nos valores de radiação solar sobre a duração do ciclo e do estádio semeadura à antese. Isto mostra que o desenvolvimento de fases no modelo CERES-maize está fundamentado no fato de que a temperatura é o principal fator climático

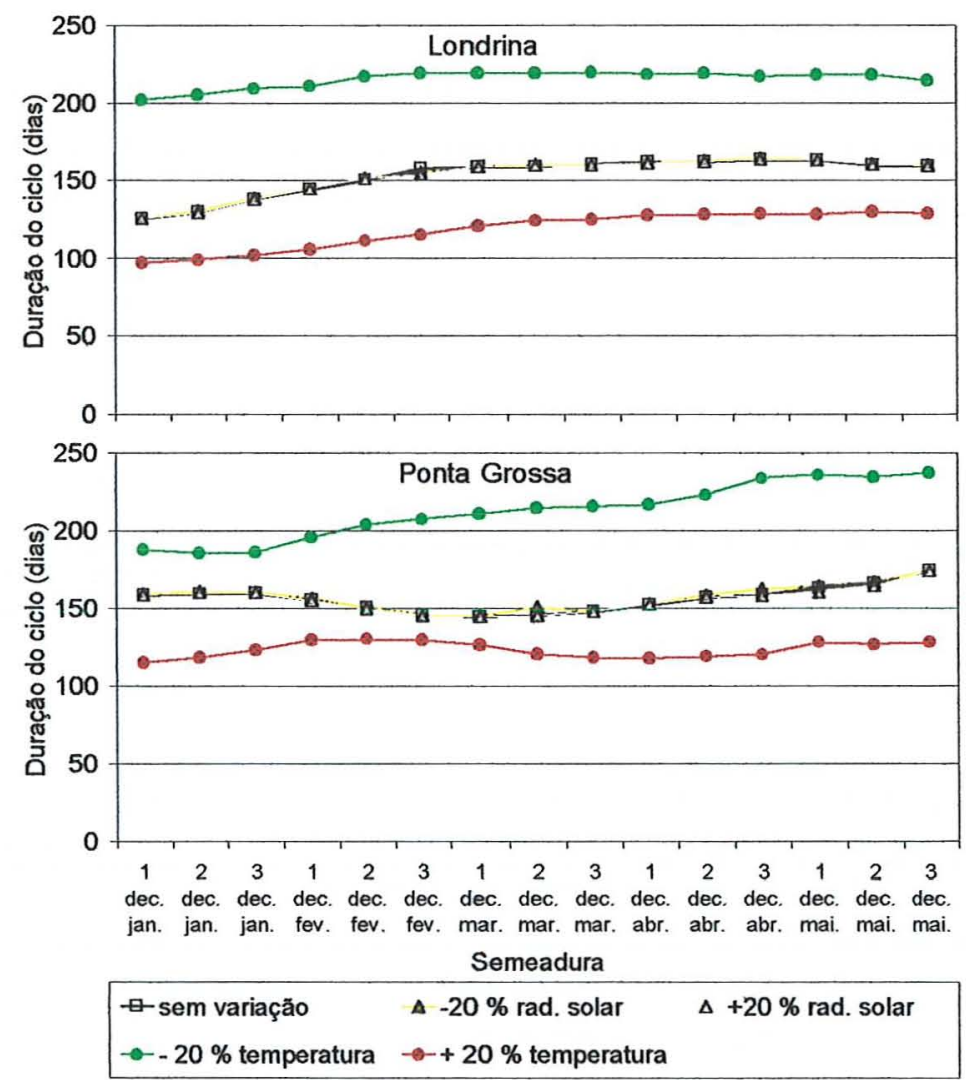

Figura 4.4. Durações médias do ciclo do milho "safrinha" devido à variações de radiação solar e temperatura em semeaduras no período de janeiro a maio para Londrina e Ponta Grossa, no cenário de produção potencial. 
que afeta a duração de estádios e ciclo da cultura, e em algumas variedades fotossensíveis também o fotoperíodo assume um papel importante, sendo estes aspectos representados no modelo pelos coeficientes genéticos (P1, P2 e P5), como já descrito em materiais e métodos.

Observa-se na Figura 4.5 a variação do número de ciclos finalizados antecipadamente devido a reduzida taxa de enchimento de grãos em função de variações $(+20 \%$ e $-20 \%)$ nos valores de radiação solar e temperatura. Observa-se que a temperatura foi o fator que mais influenciou o número de safras e ciclos afetados drasticamente, sendo que redução de $20 \%$ na temperatura tendeu a aumentar e antecipar o período de ocorrência de frustrações de safras e o aumento de $20 \%$ tendeu a diminuir e a retardar este período

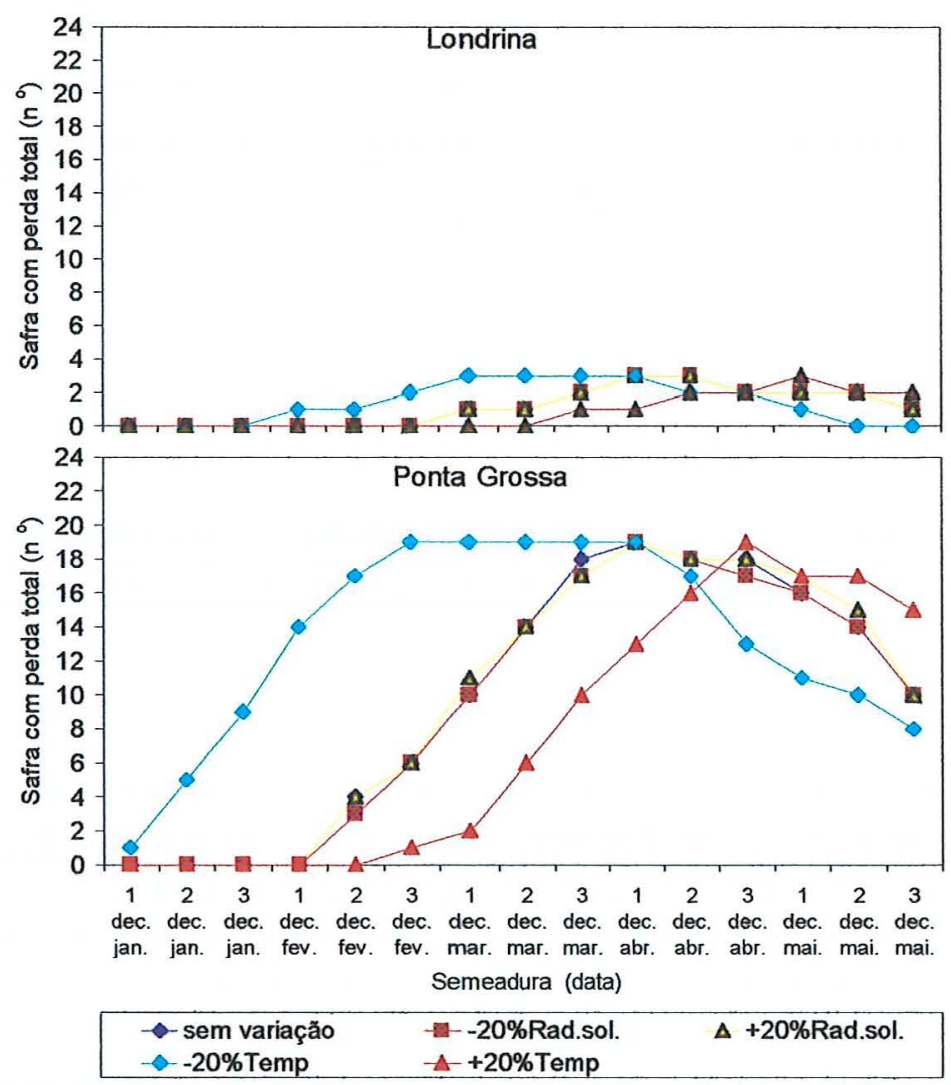

Figura 4.5. Números de safras com perda total de grãos para o milho "safrinha" devido à variações de radiação solar e temperatura em semeaduras no período de janeiro a maio para Londrina e Ponta Grossa no cenário de produção potencial. 
tanto para Londrina, como para Ponta Grossa com mais evidência.

As variações na radiação solar tiveram pouca influencia, apresentando o número de safras afetadas semelhante ao das condições simuladas com os dados da série de registros climáticos observados sem variação.

\subsubsection{RENDIMENTOS NO CENÁRIO DE PRODUÇÃO POTENCIAL}

Na Figura 4.6 observa-se os valores médios de rendimento do milho "safrinha" (cultivar XL-520) simulados para o cenário de produção potencial em Londrina e Ponta Grossa, com semeaduras no período de janeiro a maio. $\mathrm{Na}$ semeadura do $1^{\circ}$ decêndio de janeiro o rendimento potencial médio em Londrina foi semelhante ao de Ponta Grossa com aproximadamente 9700 kg.ha ${ }^{-1}$, em média. Nas semeaduras a partir do $1^{\circ}$ decêndio de janeiro, em Ponta Grossa, os rendimentos potenciais decresceram gradativamente até o $3^{\circ}$ decêndio de março, chegando em média a $1450 \mathrm{~kg} \cdot \mathrm{ha}^{-1}$, quando tenderam a aumentar novamente, alcançando $5100 \mathrm{~kg} \cdot \mathrm{ha}^{-1}$ no $3^{\circ}$ decêndio de maio. Os rendimentos de Ponta Grossa foram sempre menores que os de Londrina, devido ao grande nú-

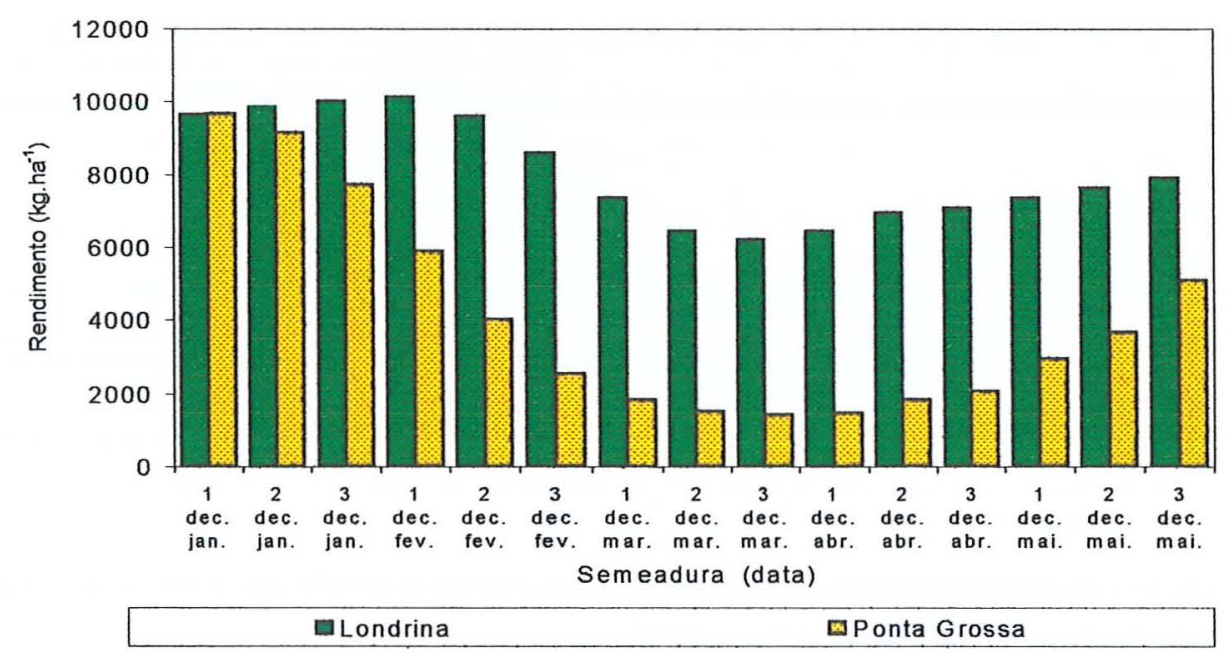

Figura 4.6. Rendimentos médios do milho "safrinha" (cultivar XL-520) semeado no período de janeiro a maio para Londrina e Ponta Grossa, no cenário de produção potencial. 
mero de safras frustradas neste local, como já comentado, e também a menor disponibilidade de radiação solar. Em Londrina, os rendimentos potenciais médios apresentaram-se inicialmente crescentes até o $1^{\circ}$ decêndio de fevereiro, chegando em média a $10150 \mathrm{~kg} \cdot \mathrm{ha}^{-1}$, depois tenderam a decrescer rapidamente quando se retardou a semeadura até o $3^{\circ}$ decêndio de março, atingindo em média a $6230 \mathrm{~kg} \cdot \mathrm{ha}^{-1}$, e retornaram a aumentar mais gradualmente a partir desta atingindo em média $7925 \mathrm{~kg} \cdot$ ha $^{-1}$, para semeaduras no $3^{\circ}$ decêndio de maio.

Os melhores rendimentos obtidos nas simulações com semeaduras em janeiro podem ser atribuidos à coincidência dos períodos mais sensiveis da cultura (florescimento e formação da produção) com condições mais favoráveis de temperatura, radiação solar e umidade do solo, minimizando os estresses.

Para Ponta Grossa, a ocorrência de baixas temperaturas, e o maior número de geadas, resultam num grande número de safras frustradas, o que junto a menor disponibilidade de radiação solar, são responsáveis pelos menores rendimentos, quando comparadas aos de Londrina.

$\mathrm{Na}$ analise de sensibilidade das simulações para Londrina (Figura 4.7), observou-se que aumentos em $20 \%$ nos valores de radiação solar proporcionaram acréscimos bastante regulares nos rendimentos médios potenciais, em torno de $17,3 \%$. Em Ponta Grossa o acréscimo na radiação solar não resultou em aumentos estáveis dos rendimentos potenciais, havendo oscilações em alguns casos. Os acréscimos médios foram em torno de $15 \%$. No caso de reduções de $20 \%$ na radiação solar verifica-se que houve decréscimos bastante regulares nos rendimentos potenciais para todas as épocas de semeadura de Londrina, cujo valor médio foi de $18,9 \%$ de decréscimo em relação a condição atual e em Ponta Grossa esta redução foi de 15,9\% apresentando algumas oscilações. Estas respostas podem ser atribuídas ao fato de o modelo assumir que a produção de biomassa para o enchimento de grãos decorre principalmente da radiação interceptada pelas folhas da planta.

As variações $(-20 \%$ e $+20 \%)$ nos valores de temperatura do ar apresentaram resultados bastante variáveis, tanto em Londrina como em Ponta Grossa, 
ora aumentando e ora reduzindo os rendimentos. Em Londrina, o decréscimo em $20 \%$ na temperatura tendeu em aumentar os valores médios de rendimento potencial para semeaduras nos dois primeiros decêndios de janeiro e a partir do $2^{\circ}$ decêndio de março, e tendeu a reduzi-los para as semeaduras nos outros decêndios. Já o aumento em $20 \%$ na temperatura em Londrina tendeu em reduzir os rendimentos médios potenciais para a maioria das épocas de semeadura, exceto na semeadura do $2^{\circ}$ decêndio de março. Isto mostra que para o milho safrinha em Londrina, em geral, aumentos de temperatura são mais prejudiciais do que decréscimos. Em Ponta Grossa, esta análise ficou prejudicada devido ao pequeno número de ciclos completados adequadamente (Figura 4.2) decorrentes dos problemas com temperaturas baixas, como já

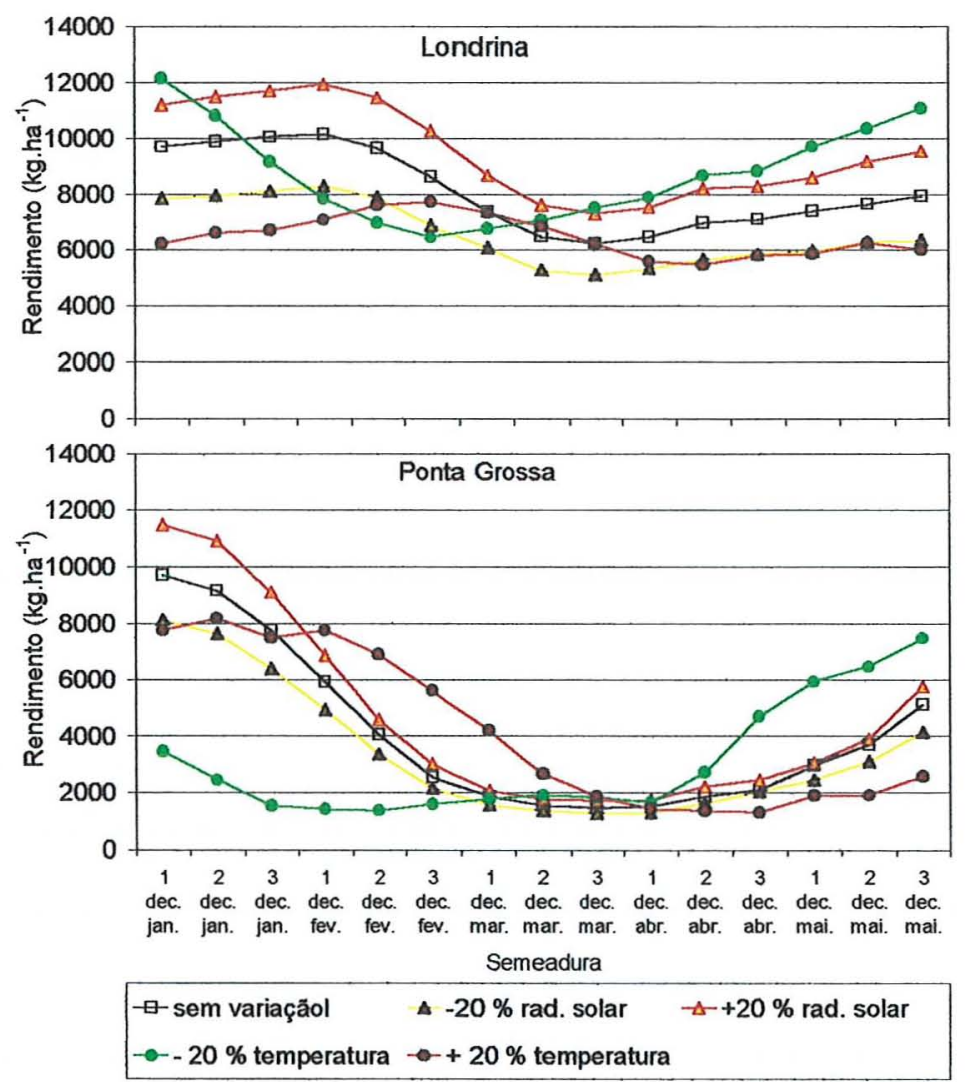

Figura 4.7. Variações médias do rendimento do milho "safrinha" devido à variações de radiação solar e temperatura em semeaduras no período de janeiro a maio para Londrina e Ponta Grossa, no cenário de produção potencial. 
mencionado na análise da fenologia, sendo estes números de ciclos variáveis dependendo das variações assumidas nos valores de temperatura. Assim na Figura 4.7 observa-se que o aumento em $20 \%$ dos valores de temperatura em Ponta Grossa promoveram reduções nos valores médios de rendimento potencial nas semeaduras do mês de janeiro e a partir de abril, apresentando aumentos nos rendimentos potenciais nas outras épocas de semeadura, chegando a valores superiores a $100 \%$ em relação à condição sem variação, devido principalmente á redução do número de ciclos interrompidos por temperaturas baixas. Já a redução em $20 \%$ na temperatura resultou em decréscimos nos rendimentos potenciais das semeaduras efetuadas até o $1^{\circ}$ decêndio de março e acréscimos nos demais, onde neste caso estas variações relativas foram bastante prejudicadas pelos motivos já mencionados anteriormente. Estes comportamentos podem ser atribuídos devido a influência da temperatura tanto na duração dos estádios e ciclo da cultura como também nas taxas de crescimento dos diversos órgãos da planta, principalmente nas taxas de enchimento de grãos, o que resulta em respostas diferentes conforme a época de semeadura adotada promovendo o confronto das temperaturas prejudiciais com diferentes estádios da planta.

Na Figura 4.8 observa-se as curvas de probabilidades acumuladas para os rendimentos médios potenciais do milho "safrinha", semeado nos 15 decêndios do período de janeiro a maio, obtidas a partir dos 24 anos de simulações para Londrina e Ponta Grossa. Para Londrina, a partir da análise da dominância de $2^{\circ}$ grau, verifica-se que em geral os melhores resultados de rendimentos potenciais para o milho "safrinha" são obtidos para a semeadura no $1^{\circ}$ decêndio de fevereiro e os piores rendimentos potenciais correspondem a semeadura no $3^{\circ}$ decêndio de março.

Em Ponta Grossa, os maiores rendimentos potenciais, em geral, foram obtidos na semeadura do $1^{\circ}$ decêndio de janeiro e os menores rendimentos potenciais resultaram das simulações com semeadura no $3^{\circ}$ decêndio de março. Observam-se também altos riscos de frustrações de safras nas 
semeaduras a partir do $2^{\circ}$ decêndio de fevereiro. A análise risco é melhor caracterizada pelos resultados apresentados na Figura 4.9, em que apresentam-se os valores médios de rendimentos esperados ao nível dos percentis 10, 25, 50, 75 e 90\% de probabilidade para Londrina e Ponta Grossa.

Nota-se que em Londrina, os rendimentos potenciais nulos apresentam uma baixa probabilidade de ocorrência em algumas das épocas de semeadura analisadas. A nível de $10 \%$ de probabilidade pode-se esperar que ocorram perdas totais de safras apenas nos dois primeiros decêndios de abril e para um nível de $25 \%$ de probabilidade pode-se esperar rendimentos médios potenciais superiores a $6000 \mathrm{~kg} \cdot \mathrm{ha}^{-1}$.
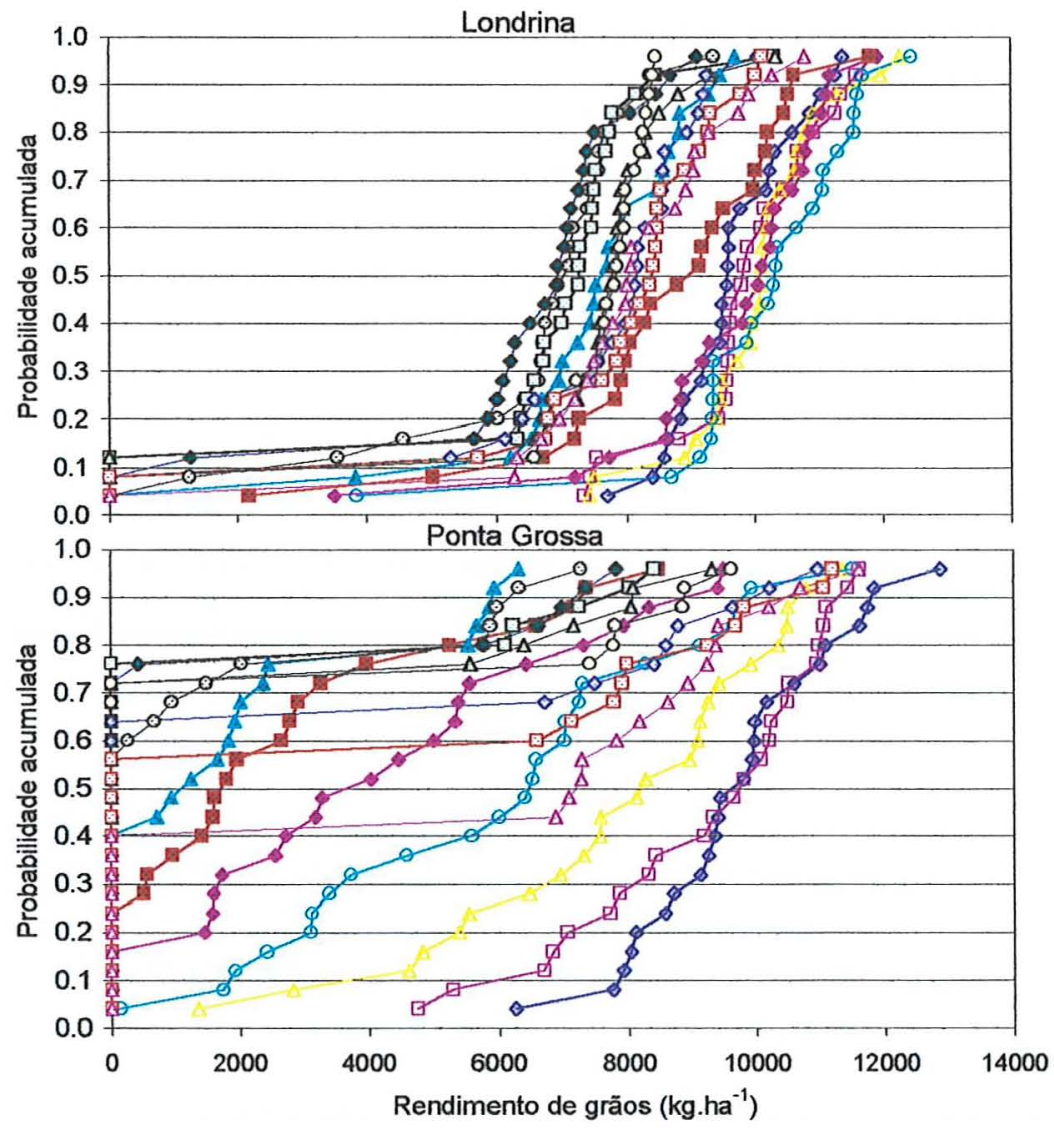

\begin{tabular}{|c|c|c|c|c|}
\hline$\diamond-1$ dec. jan. & -曰-2 dec. jan. & 3 dec. jan. & -1 dec. fev. & $\neg 2$ dec fev. \\
\hline -둘-3 dec. fev. & -1 dec. mar. & - 2 dec. mar. & -3 dec. mar. & $\neg-1$ dec. abr. \\
\hline$-\Delta-2$ dec. abr. & $-0-3$ dec. abr. & $\diamond-1$ dec. mai. & - 낭 2 dec mai. & $-\Delta 3$ dec. mai. \\
\hline
\end{tabular}

Figura 4.8. Probabilidades acumuladas rendimento médio do milho "safrinha" (cultivar XL-520) semeado no período de janeiro a maio para Londrina e Ponta Grossa, no cenário de produção potencial. 
Em Ponta Grossa, a nível de $10 \%$ de probabilidade pode-se esperar rendimentos médios potenciais nulos nas semeaduras a partir do $2^{\circ}$ decêndio de fevereiro e a nível de $90 \%$ de probabilidade pode-se esperar rendimentos médios superiores a $5900 \mathrm{~kg} \cdot \mathrm{ha}^{-1}$ ao longo dos decêndios analisa-dos. Observa-se que para semeaduras entre $\circ 2^{\circ}$ decêndio de março e $\circ 2^{\circ}$ decêndio de maio o risco de perdas totais de safras é superior a $50 \%$ de probabilidade chegando na semeadura do $1^{\circ}$ decêndio de abril a ser superior a $75 \%$ de probabilidade.
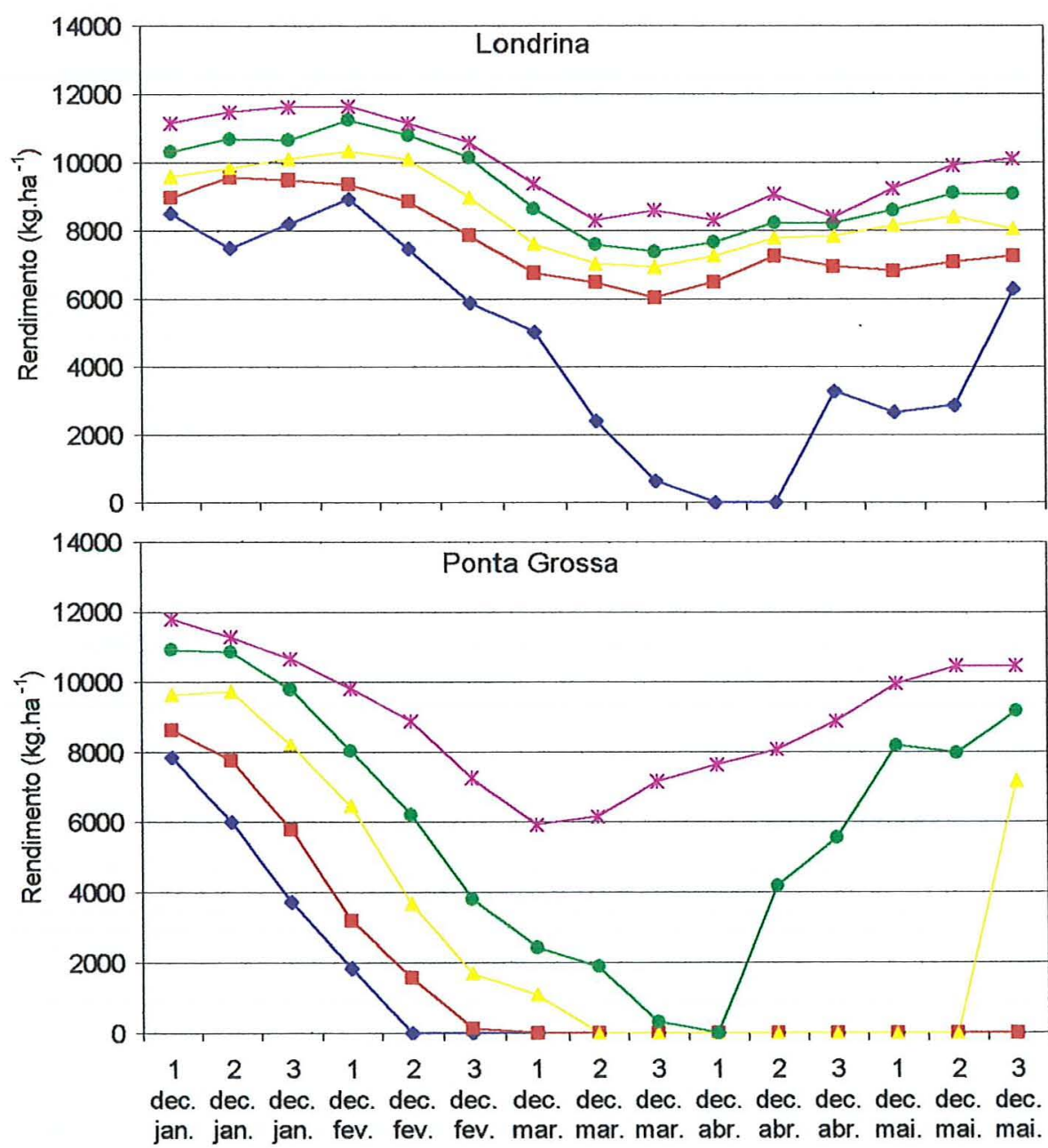

Semeadura (decêndio)

\begin{tabular}{lllll}
\hline$\rightarrow 10 \%$ & $-25 \%$ & $50 \%$ & $-75 \%$ & $-75 \%$ \\
\hline
\end{tabular}

Figura 4.9. Rendimentos médios esperados à nível de $10,25,50,75$ e $90 \%$ de probabilidade para o milho "safrinha" semeado de janeiro a maio para Londrina e Ponta Grossa no cenário de produção potencial. 


\subsection{SIMULAÇÕES PARA O CENÁRIO SEM IRRIGAÇÃO}

Neste cenário considerou-se um manejo sem irrigação, a água demandada pelas culturas era suprida apenas pelas chuvas, podendo ser, neste caso, um fator limitante, além de outros, como o nitrogênio e temperaturas extremas, permitindo a análise da influência destes fatores adversos que confrontam-se com a cultura em diferentes fases de seu ciclo de desenvolvimento, o que dependendo da época de semeadura adotada, resultou em implicações no estabelecimento e fenologia, produtividade e lucratividade do milho "safrinha" nos locais estudados. Cabe salientar que neste cenário, o modelo representa os estresses por fatores de redução (pesos de 0 até 1) de acordo com o seu nível de severidade, sendo que o crescimento e rendimento da cultura fica condicionado pelo fator mais limitante.

\subsubsection{ESTABELECIMENTO DA CULTURA E ASPÉCTOS FENOLÓGICOS}

Na Figura 4.10, apresentam-se os números de falhas para o estabelecimento da cultura do milho "safrinha", cultivar XL-520, em Londrina e Ponta Grossa, com semeadura ao longo dos 15 decêndios no periodo de janeiro a maio, para a série de 24 anos de simulações (1976 a 1999), com o modelo CERES-Maize, sob o cenário sem irrigação. No modelo, considerou-se que o estabelecimento da cultura ocorria apenas quando certas condições ideais de umidade e temperatura do solo (vide materiais e métodos) estivessem presentes ao longo do decêndio, sendo que na ausência de uma destas condições, o modelo não simulou o ciclo da cultura, considerando-se como falha no estabelecimento da cultura naquele determinado decêndio do ano em questão.

Observou-se um aumento nos riscos de estabelecimento a medida que a semeadura foi atrasada de fevereiro a inicio de maio, podendo ser atribuído à 


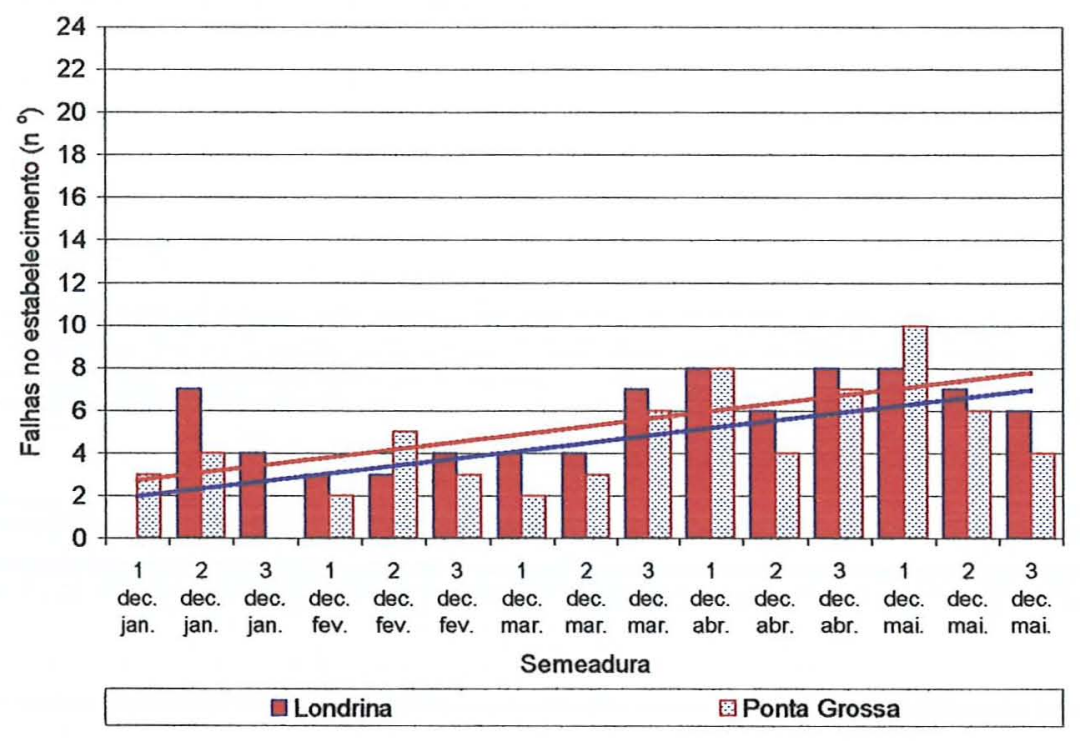

Figura 4.10. Frequência de falhas decendiais no estabelecimento do milho "safrinha" (cultivar XL-520) semeado no período de janeiro a maio para Londrina e Ponta Grossa, no cenário sem irrigação

redução da disponibilidade hídrica no solo, decorrente da redução na ocorrência de chuvas neste período (vide valores médios na tabela $3.3 \mathrm{em}$ materiais e métodos), o que ficou mais evidenciado em Londrina. Uma maior variabilidade na distribuição das chuvas, principalmente no número de ocorrência, resultou em uma maior variação no número de falhas no estabelecimento do milho "safrinha" em Ponta Grossa.

A análise de sensibilidade demonstrou que a chuva foi o fator que mais influenciou nos riscos de estabelecimento da cultura. O decréscimo $(-20 \%)$ de chuva resultou em maior número de falhas de estabelecimento em algumas épocas de semeadura. Por outro lado, menor número de falhas ocorreu quando a chuva aumentou em $20 \%$. Verificou-se ainda, nesta análise, que a temperatura do ar apresentou um efeito indireto, decorrente de sua contribuição para a variação da evapotranspiração e, assim, um maior ou menor esgotamento da água armazenada no solo, onde o decréscimo de $20 \%$ na temperatura tendeu a um pequeno aumento no número de falhas e o acréscimo de $20 \%$ na temperatura tendeu em diminuir um pouco o número de falhas em 
alguns decêndios, não afetando diretamente o estabelecimento da cultura, quanto à temperatura do solo. As variações na radiação solar não resultaram em variações no número de falhas no estabelecimento.

Então, sendo a radiação solar e temperatura do solo não limitante nesta época do ano, estas falhas no estabelecimento ocorreram devido a umidade no solo encontrar-se abaixo de $50 \%$ da capacidade de armazenamento de água disponível ao longo de todo o decêndio em questão, condição esta assumida como critério para emergência nas simulações com o modelo. Neste aspecto, cabe aqui salientar uma limitação do modelo, o qual não considera a impossibilidade de plantio devido ao excesso de chuvas, não assumindo esta condição como falha de estabelecimento da cultura, ou seja, no primeiro dia em que a umidade do solo supere a condição minima de $50 \%$ de $A D$ (água disponível), admitiu-se o seu estabelecimento, mesmo ocorrendo chuva nesta data, impossibilitando a trafegabilidade de máquinas na lavoura.

$\mathrm{Na}$ Figura 4.11 são apresentadas as funções de probabilidade acumulada das durações dos ciclos para épocas de semeadura, em cada decêndio dos meses de janeiro a maio. Em Londrina poucos ciclos foram afetados drasticamente por temperaturas baixas, ou seja, nestes casos, os ciclos não foram completados adequadamente, afetando a produção de grãos, os quais ocorreram em poucos anos afetando nestes a maioria do decêndios analisados. Já em Ponta Grossa, devido a maior ocorrência de temperaturas baixas e geadas, os ciclos do milho "safrinha" tiveram uma grande variação em seus comprimentos, sendo que, em geral, os ciclos menores que 150 dias proporcionaram rendimentos baixissimos ou muitas vezes nulos.

Desconsiderando os ciclos afetados drasticamente por temperaturas muito baixas os quais são relacionados na Figura 4.12, as duraçōes médias dos ciclos mostraram uma tendência em alongar-se a medida que se retardou a semeadura até abril, tendendo a decrescer quando a semeadura ocorreu nos decêndios do mês de maio. Isto decorre do confronto das fases do ciclo da cultura com temperaturas mais baixas durante o inverno (alongamento do ciclo) 

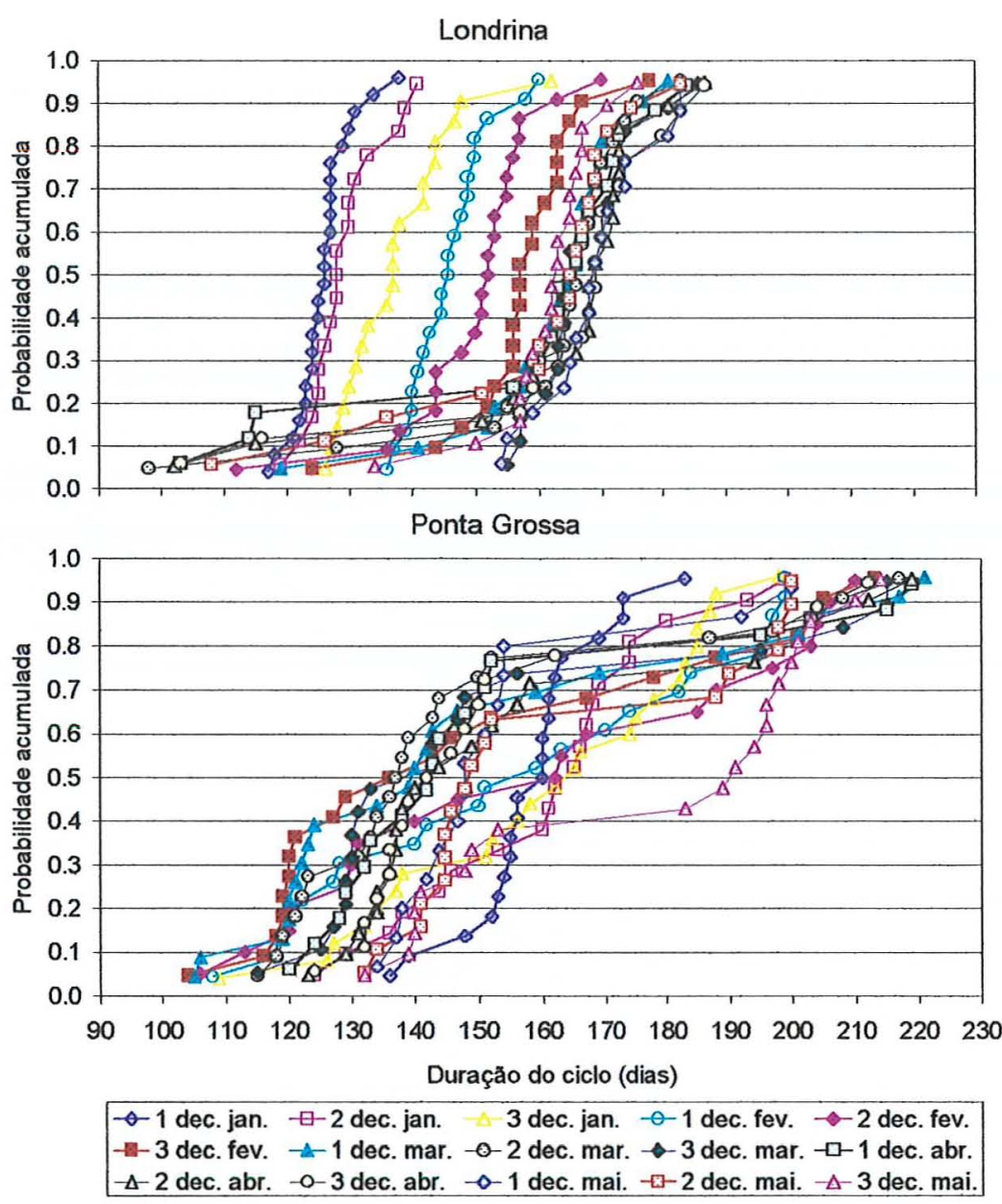

Figura 4.11. Probabilidades acumuladas da duração do ciclo do milho "safrinha" (cultivar XL-520) semeado no período de janeiro a maio para Londrina e Ponta Grossa, no cenário sem irrigação.

ou temperaturas mais elevadas nas demais estações (encurtamento do ciclo).

As durações do ciclo foram maiores em Ponta Grossa do que em Londrina para todas as épocas de plantio, decorrentes de um inverno mais rigoroso nesta primeira, fazendo com que as plantas necessitassem um maior número de dias para totalizar as unidades térmicas necessárias para completar os seus ciclos produtivos e ficando assim mais tempo expostas às condições adversas, ao que se atribui a maior variabilidade nas durações de ciclo e rendimentos.

Também, neste cenário, como no cenário de produção potencial, observou-se que em média a duração do estádio semeadura à antese tendeu a aumentar gradativamente quando se retardou a semeadura até maio, mostrando 


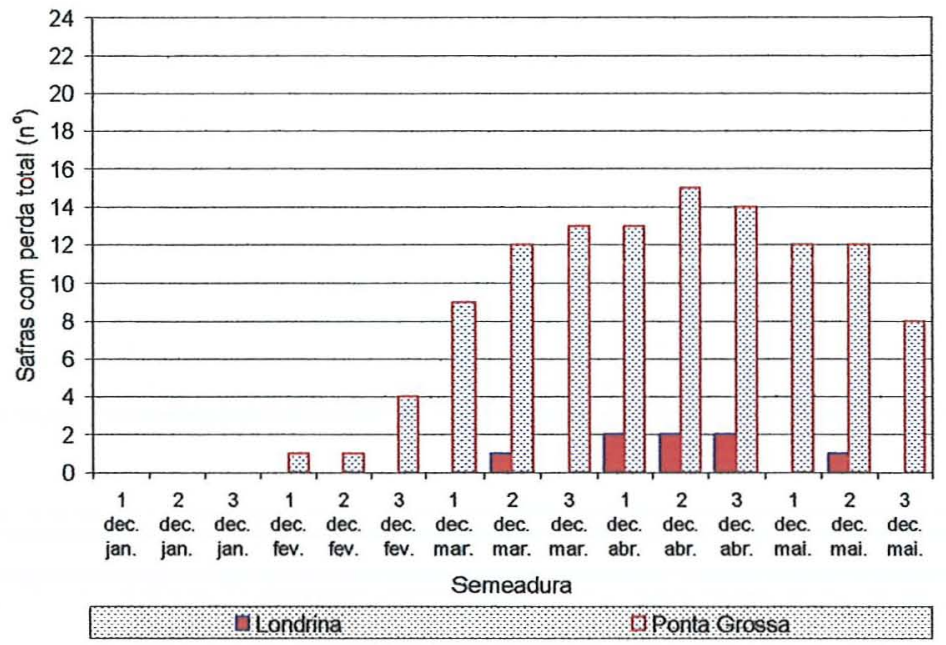

Figura 4.12. Número de safras com ciclo interrompido e perda total de grãos para o cenário sem irrigação em 24 anos de simulações para Londrina e Ponta Grossa.

que o modelo foi sensível quanto a resposta às variações de temperatura sobre a duração dos estádios e do ciclo total, decorrente da época de semeadura adotada, o que ficou mais evidente na análise de sensibilidade como discutido anteriormente no cenário de produção potencial.

Na Figura 4.13 são apresentadas as funções de probabilidade acumulada das datas (dias julianos) da maturação fisiológica, que é assumida pelo modelo como data de colheita, ou seja, datas em que a área ficaria disponível para o cultivo subsequente da cultura de verão. Analisando-se as linhas de probabilidade fica evidente a maior variação nas durações dos ciclos do milho "safrinha" em Ponta Grossa, decorrentes, principalmente, da influência das temperaturas baixas, agindo tanto no alongamento das fases vegetativas e reprodutivas, bem como interrompendo drasticamente o ciclo de crescimento e prejudicando a produção final de grãos. Nota-se que em Londrina a área para o cultivo subsequente fica disponibilizada mais cedo que em Ponta Grossa.

Observa-se também que, para não retardar a semeadura da cultura de verão para além do mês de outubro, a cultura de "safrinha" deverá ser plantada até o final do mês de abril em Londrina e março em Ponta Grossa, sendo que após estas os riscos de atraso para o cultivo de verão são maiores. 
Devido ao alongamento na duração dos ciclos da cultura em Ponta Grossa, em anos com inverno rigoroso, o risco de atraso para a liberação da área para a exploração da cultura de verão pode ocorrer mesmo para plantios anteriores ao mês de março.

Estas informações de probabilidade das datas de colheitas tornam-se também importantes para o planejamento da comercialização ou para o armazenamento da produção do milho "safrinha", possibilitando a sua venda em épocas em que os preços do produto sejam mais atrativos ou, até mesmo, para o planejamento de colheitas escalonadas permitindo a otimização do uso das máquinas e mão de obra na exploração desta cultura.
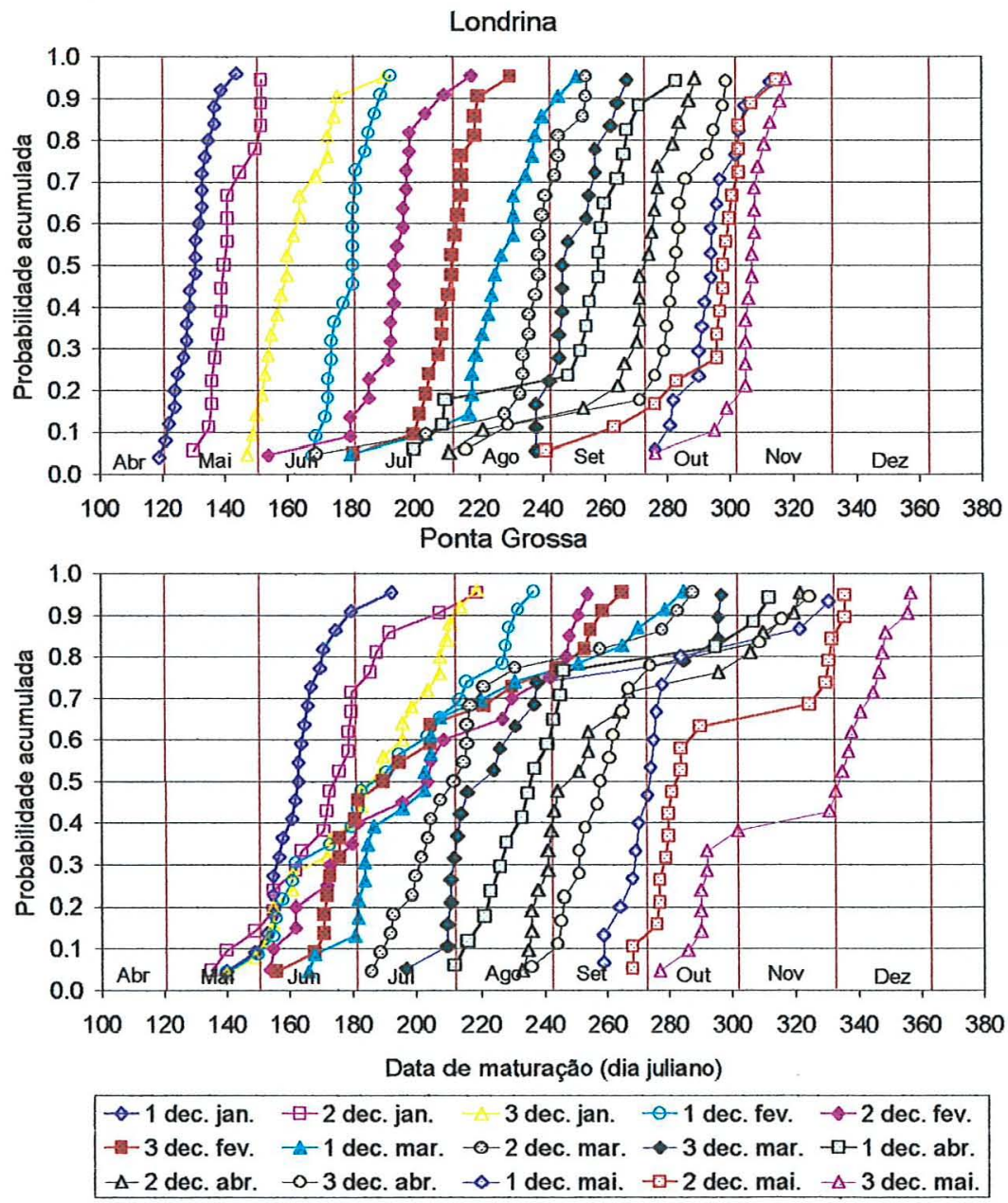

Figura 4.13. Probabilidades acumuladas de datas de colheita do milho "safrinha" semeado no período de janeiro a maio para Londrina e Ponta Grossa, no cenário sem irrigação. 


\subsubsection{RENDIMENTO DE GRÃOS NO CENÁRIO SEM IRRIGAÇÃO}

Os resultados da simulação de rendimento para os cenário sem irrigação e de produção potencial do milho "safrinha" (cultivar XL-520) em Londrina e Ponta Grossa, para as épocas de semeadura no período de janeiro a maio, em 24 anos de simulação (1976 a 1999), com o modelo CERES-Maize, são mostrados nas Figuras 4.14 e 4.15.

A medida que a semeadura foi atrasada até abril os ciclos simulados foram maiores e as condições ambientais foram mais adversas para a cultura. Os ciclos mais longos ficaram mais tempo expostos às condições ambientais adversas, determinando a finalização abrupta do período de enchimento do grão, devido ao lento enchimento dos mesmos.

Observa-se na Figura 4.14, que para o cenário sem irrigação, em Ponta Grossa os rendimentos médios tenderam a decréscimos gradativos a medida que a semeadura foi atrasada até o início de maio (com uma pequena oscilação para as safras semeadas em abril), tendendo a aumentar posteriormente. Cabe salientar que estes valores são bastante influenciados pela grande variação nos números de falhas no estabelecimento, e também, principalmente, dos números de safras com rendimentos nulos. Em Londrina, verificou-se uma grande oscilação dos valores médios de rendimentos ao longo das semeaduras dos decêndios analisados. Isto pode ser atribuído a menor ocorrência e distribuição de chuvas associado a temperaturas baixas, principalmente ao longo da estação de inverno, chegando às vezes até a ocorrer geadas, coincidindo com as fases críticas do cultivo (florescimento e formação da produção) o que vem a resultar em frustrações de safras. Então, os rendimentos foram menores em Ponta Grossa devido, principalmente, a menor disponibilidade energética (térmica) desta região, ou seja menores valores de radiação solar e temperatura do ar (vide tabela 3.3) o que resultou principalmente em um grande número de safras com rendimento nulo, principalmente para as semeaduras a partir de março. 

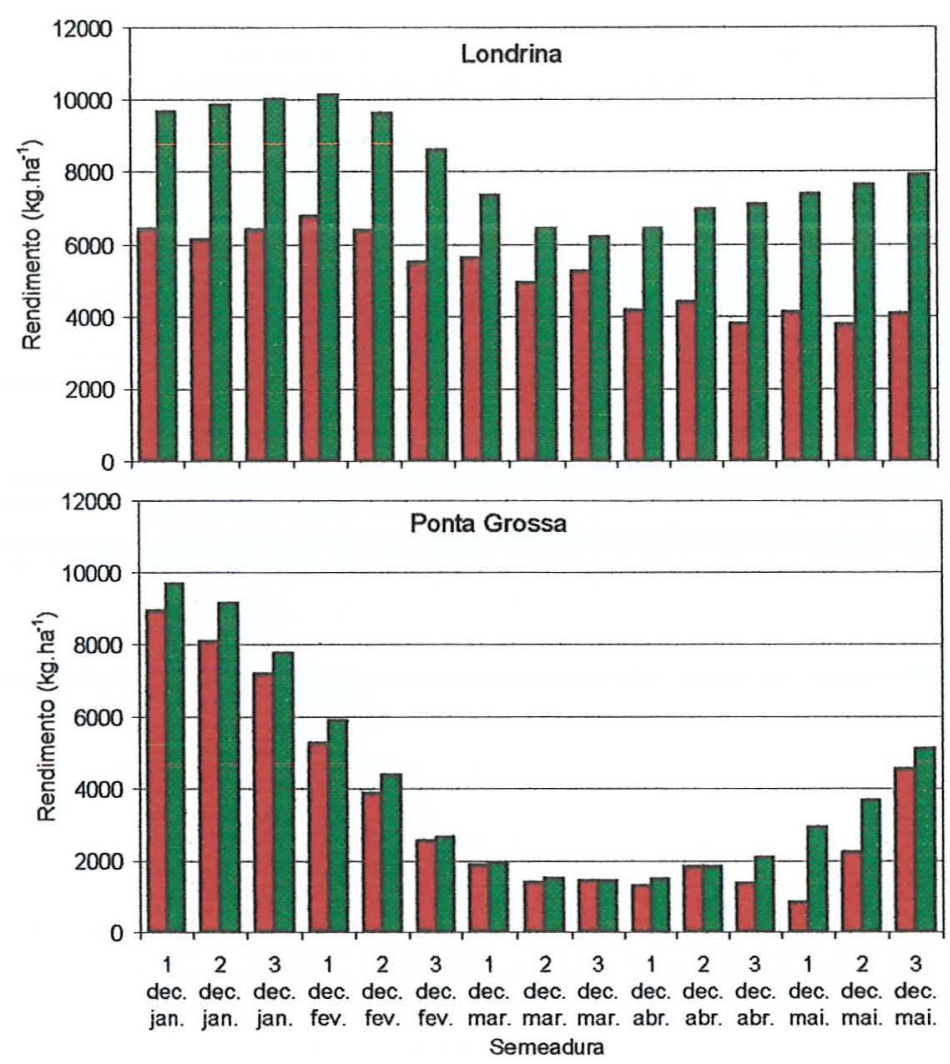

Semeadura

Figura 4.14. Rendimentos médios do milho "safrinha" (cultivar XL-520) semeado no período de janeiro a maio para Londrina e Ponta Grossa, nos cenários de produção potencial e sem irrigação.

A maior diferença entre rendimentos do cenário sem irrigação e de produção potencial (redução de $35,4 \%$, em média) em Londrina pode ser atribuído, principalmente, à menor ocorrência e distribuição de chuvas e disponibilidade de nitrogênio ao longo dos ciclos de cultivo. Em Ponta Grossa o fator mais determinante para os baixos rendimentos (redução de $14,5 \%$, em média) foi, com certeza, a baixa temperatura. Assim, a irrigação em Londrina parece ser uma alternativa promissora para o cultivo do milho "safrinha" e sua viabilidade será analisada a diante.

A Figura 4.15 , relaciona as probabilidades acumuladas com os rendimentos simulados sob o cenário sem irrigação. Para Londrina, a partir da análise da dominância estocástica de $2^{\circ}$ grau, verificou-se que em geral os melhores resultados de rendimentos sob chuva natural para o milho "safrinha" 
são obtidos para a semeadura no $1^{\circ}$ decêndio de fevereiro e os piores rendimentos correspondem a semeadura no $2^{\circ}$ decêndio de maio. Em Ponta Grossa, os maiores rendimentos sob chuva natural em geral são obtidos na semeadura do $1^{\circ}$ decêndio de janeiro, sendo também no $1^{\circ}$ decêndio de maio os menores rendimentos. Observou-se, também, altos riscos de frustrações de safras em Ponta Grossa nas semeaduras a partir do $2^{\circ}$ decêndio de fevereiro. Estes riscos ficam melhor caracterizados na Figura 4.16, onde apresenta-se os valores médios de rendimentos esperados ao nível de 10, 25, 50, 75 e $90 \%$ de probabilidade para o milho "safrinha" em Londrina e Ponta Grossa.

Os menores riscos de frustrações de safras em Ponta Grossa foram obtidos em semeaduras até fevereiro, sendo que após este mês a probabilidade de frustrações de safras torna-se bastante alta. Nota-se ainda que em alguns
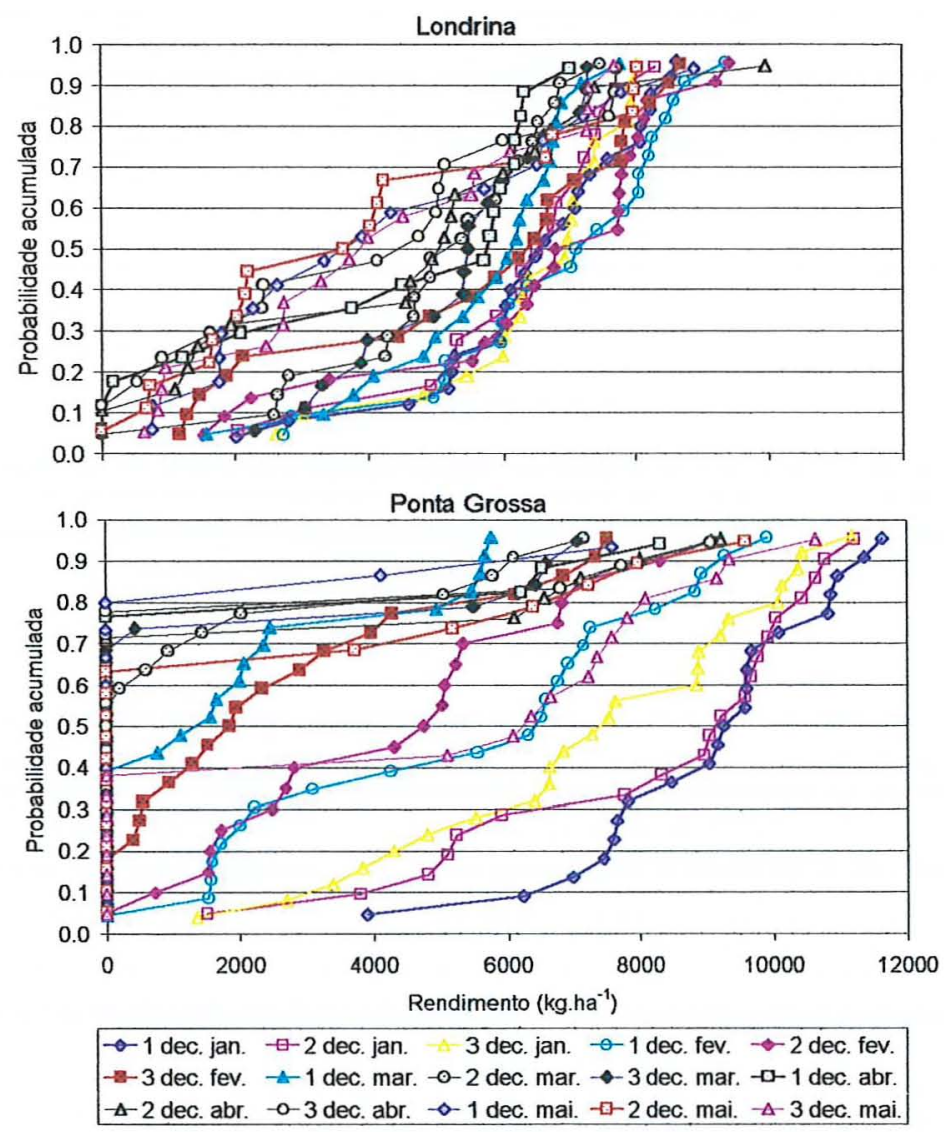

Figura 4.15. Probabilidades acumuladas do rendimento médio do milho "safrinha" (cultivar XL-520) semeado no período de janeiro a maio para Londrina e Ponta Grossa, no cenário sem irrigação. 
casos valores de rendimento esperados foram maiores em Ponta Grossa do que em Londrina (semeaduras em janeiro).

Estas diferenças nos valores médios dos rendimentos e riscos entre Londrina e Ponta Grossa decorrem das diferenças das características fisicohídricas dos solos e das condições climáticas, principalmente dos seus diferentes regimes térmicos (temperaturas) e hídricos (ocorrência e distribuição de chuvas) além da disponibilidade de energia (Radiação solar). Outros fatores, tais como, nutrientes que não o nitrogênio, pragas, doenças, além de outros, que não foram considerados no modelo, também são importantes na determinação dos diferentes patamares de rendimento.
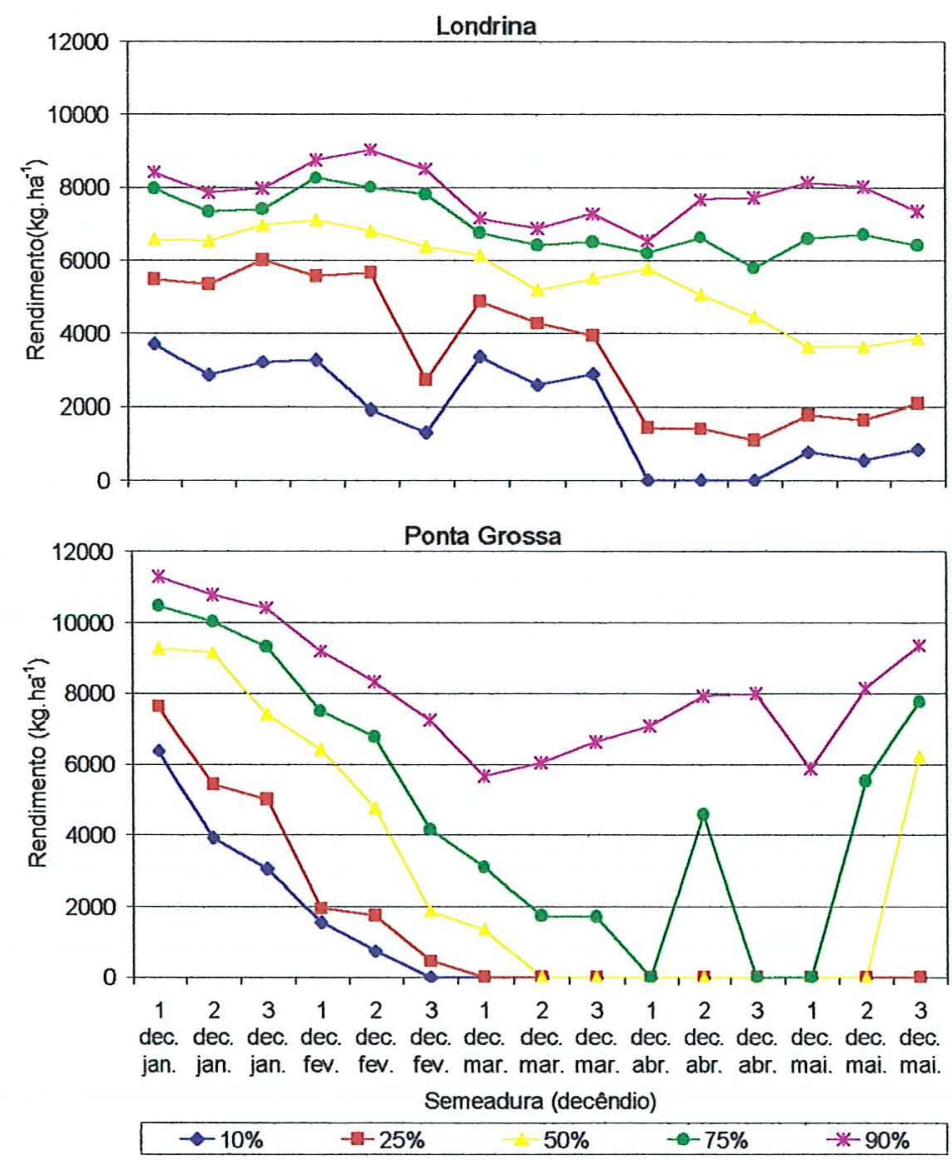

Figura 4.16. Rendimentos médios esperados à nível de 10,25, 50, 75 e $90 \%$ de probabilidade para o milho "safrinha" semeado no período de janeiro a maio para Londrina e Ponta Grossa, no cenário sem irrigação. 


\subsubsection{ANALISE ECONÔMICA PARA O CENÁRIO SEM IRRIGAÇÃO}

Na sequência analisa-se a viabilidade econômica da exploração desta cultivar (XL-520) nos locais abordados neste estudo no cenário sem irrigação.

$\mathrm{Na}$ Figura 4.17, encontram-se os valores médios das receitas líquidas obtidos para o milho "safrinha" (cultivar XL-520) em Londrina e Ponta Grossa en ém irrigação, nas 15 épocas de semeaduras. Observa-se que em Londrina, o melhor resultado médio $\left(R \$ 502 \mathrm{ha}^{-1}\right)$ foi obtido nas semeaduras do $1^{\circ}$ decêndio de fevereiro tendendo a decrescer posteriormente (chegando a $\mathrm{R} \$ 165 \mathrm{ha}^{-1}$, no $2^{\circ}$ decêndio de maio), com pequenas elevações em alguns de-

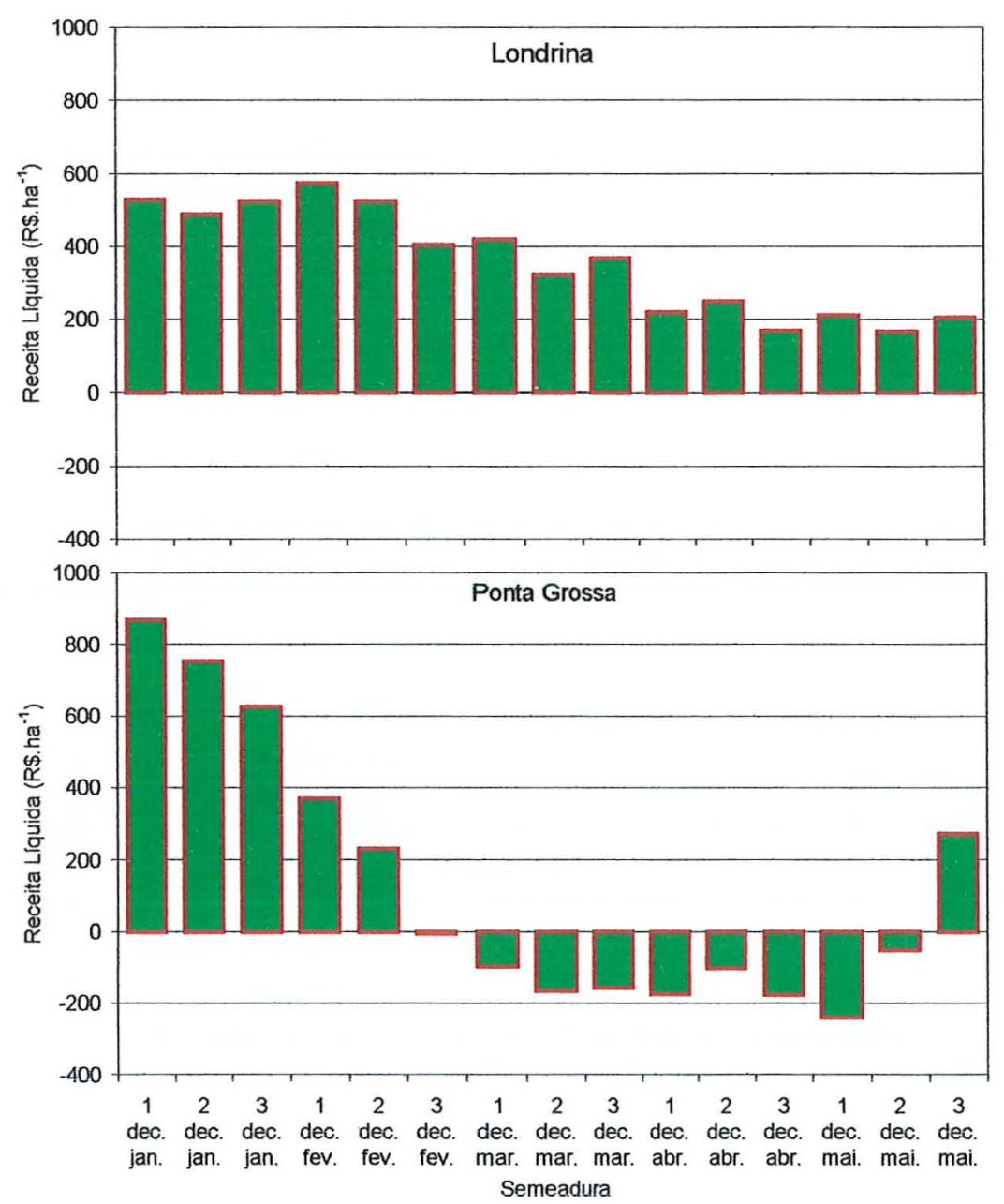

Figura 4.17. Receita Líquida média do milho "safrinha" (cultivar XL-520), para o cenário sem irrigação, semeado no período de janeiro a maio, em 24 anos de simulações para Londrina e Ponta Grossa. 
cêndios. Os valores médios de receita líquida foram superiores a $R \$ 200 \mathrm{ha}^{-1}$, na maioria do decêndios exceto para $\circ 3^{\circ}$ decêndio de abril e $2^{\circ}$ decêndio de maio. Em Ponta Grossa receitas líquidas negativas foram obtidos nas semeaduras entre $\circ 3^{\circ}$ decêndio de fevereiro e o $2^{\circ}$ decêndio de maio. $O$ maior lucro foi obtido na semeadura do $1^{\circ}$ decêndio de janeiro $\left(R \$ 860 \mathrm{ha}^{-1}\right)$ e o maior prejuizo na semeadura do $1^{\circ}$ decêndio de maio ( $R \$ 240 \mathrm{ha}^{-1}$ ).

Variações de receita líquida apresentaram o mesmo comportamento das variações dos rendimentos pois o custo de produção foi considerado sendo um valor constante, independente da época de semeadura e do volume produzido.

Os riscos associados às épocas de semeaduras do período de janeiro à maio, para os dois locais do estudo, ficam melhor evidenciados na Figura 4.18 com suas respectivas funções de probabilidade acumulada dos lucros obtidos. Fica bem evidente que em Ponta Grossa, altas probabilidades de prejuízos estão associados praticamente em todas as épocas de semeadura. Em Londrina também existe a possibilidade de ocorrência de receitas negativas (prejuízos) porém com baixas probabilidades de ocorrência.

Para Londrina, a partir da análise da dominância estocástica de $2^{\circ}$ grau, verificou-se que em geral os melhores resultados de receitas líquidas sob chuva natural para o milho "safrinha" são obtidos para a semeadura no $1^{\circ}$ decêndio de fevereiro $e$ as piores receitas líquidas correspondem a semeadura no $2^{\circ}$ decêndio de maio. Em Ponta Grossa, as maiores receitas líquidas sob chuva natural são obtidos na semeadura do $1^{\circ}$ decêndio de janeiro, sendo no $1^{\circ}$ decêndio de maio os menores rendimentos. Observou-se altos riscos de frustrações de safras em Ponta Grossa nas semeaduras a partir do $1^{\circ}$ decêndio de fevereiro.

Neste contexto, podemos inferir que em Ponta Grossa, o cultivo extemporâneo desta cultivar de milho $(X L-520)$, escolhido para este estudo, além do mês de janeiro, com o nivel de manejo estabelecido nos tratamentos, não seria viável mesmo para as semeaduras com receita líquida positiva, devido ao alto risco de frustrações de safras associadas às mesmas. 

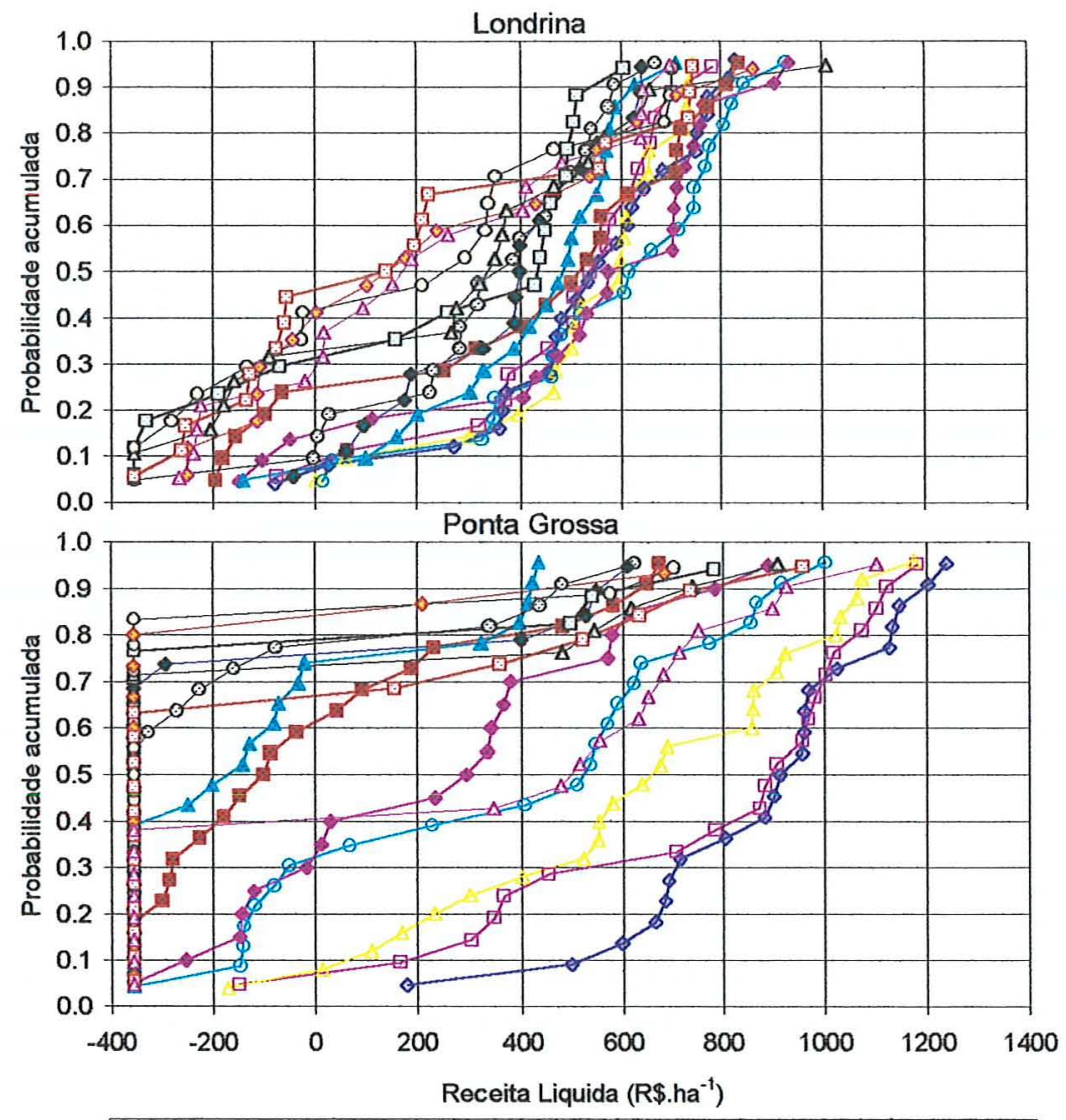

$-0-1$ dec. jan. $\square-2$ dec. jan. 3 dec. jan. $\rightarrow-1$ dec. fev. -2 dec. fev.
-3 dec. fev. $\rightarrow-1$ dec. mar. $-2-2$ dec. mar. $\rightarrow-3$ dec. mar. $\rightarrow-1$ dec. abr.
$-\Delta-2$ dec. abr. $-0-3$ dec. abr. $-0-1$ dec. mai. $\rightarrow-2$ dec. mai. $\rightarrow-3$ dec. mai.

Figura 4.18. Probabilidades acumuladas da receita líquida do milho "safrinha" (cultivar XL-520) semeado no período de janeiro a maio para Londrina e Ponta Grossa, no cenário sem irrigação.

Na Figura 4.19, são apresentadas os valores máximos esperados aos níveis de 10, 25, 50, 75 e 90\% de probabilidade. Observa-se que em Londrina, valores médios de receita líquida negativas (prejuízos) ao nível de $10 \%$ de probabilidades são esperados em semeaduras no $2^{\circ}$ e $3^{\circ}$ decêndio de fevereiro e a partir do $1^{\circ}$ decêndio de abril, sendo que nestes últimos também se espera prejuízos com probabilidades superiores a $25 \%$. Ao nível de $50 \%$ de probabilidade os valores médios esperados de receita líquida são positivas em todas as épocas de semeaduras, sendo sempre superiores a $R \$ 140 \mathrm{ha}^{-1}$. Em Ponta Grossa ao nível de $10 \%$ de probabilidade pode-se esperar receita líquida 
positiva apenas nas semeaduras de janeiro. Com $50 \%$ de probabilidade podese esperar receita líquida negativa do $3^{\circ}$ decêndio de fevereiro ao $2^{\circ}$ decêndio de maio. Receitas negativas também são esperadas ao nível de $75 \%$ de probabilidade nas semeaduras entre o $2^{\circ}$ decêndio de março ao $1^{\circ}$ decêndio de maio exceto no $2^{\circ}$ decêndio de abril. Estes altos valores de riscos são decorrentes do grande número de safras frustradas devido às condições térmicas adversas e menor disponibilidade de radiação solar.

Verificou-se na análise de sensibilidade que variações $-20 \%$ e $+20 \%$ nos valores de custo total de produção em Londrina resultaram em aumentos ou despescimos regulares e constantes (em torno de $20 \%$ ) nos valores de recei-

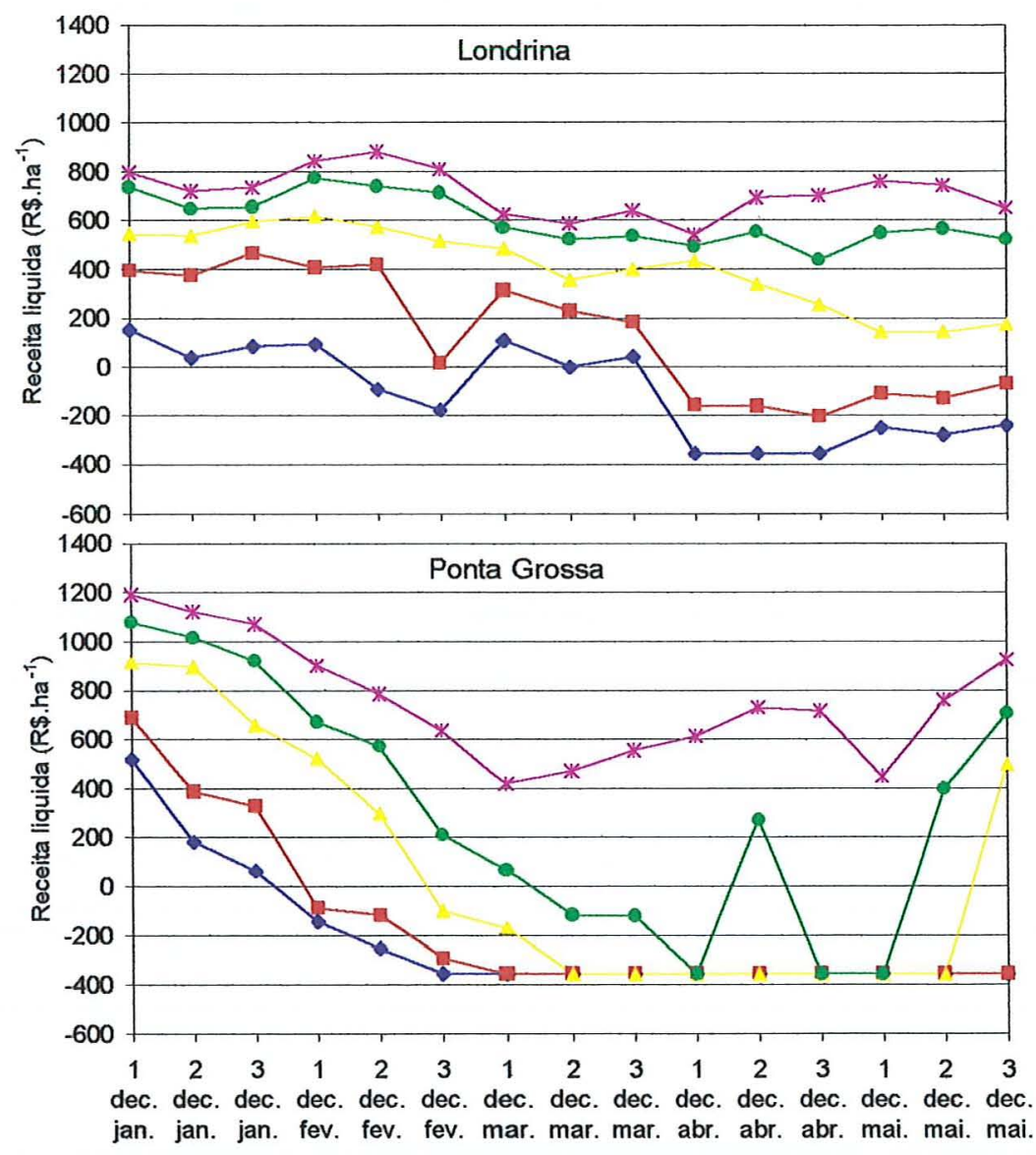

Semeadura (decêndio)

Figura 4.19. Rendimentos médios esperados à nível de 10, 25, 50, 75 e $90 \%$ de probabilidade para o milho "safrinha" semeado no período de janeiro a maio para Londrina e Ponta Grossa, no cenário sem irrigação. 
ta líquida e em Ponta Grossa a variação resultante ficou em torno de $55 \%$ de aumento ou decréscimo em relação à condição sem variação. Variando o preço do produto para o valor mínimo ou máximo as variações nos valores de receita líquida são proporcionais aos valores de rendimento, ou seja quanto maior o rendimento maiores são as reduções ou acréscimos em relação à condição atual. Em termos médios, quando adotou-se o preço mínimo ocorreram reduções de receita líquida em torno de $40 \%$ e $75 \%$ em Londrina e Ponta Grossa, respectivamente. Já quando foi adotado o valor máximo do preço do milho ocorrem aumentos de RL de $71 \%$ e $133 \%$ em Londrina e Ponta Grossa, respectivamente (Figura 4.20).

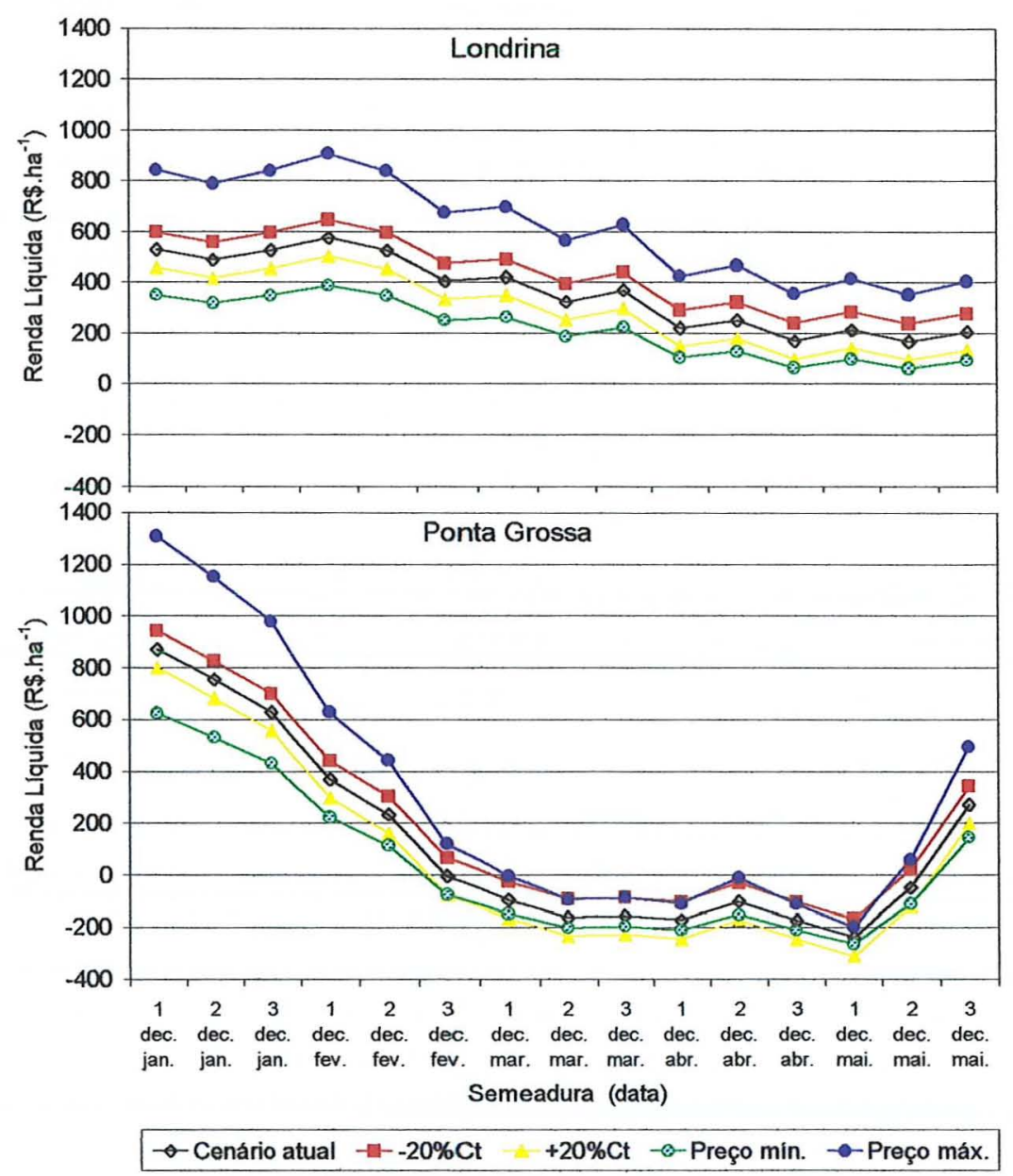

Figura 4.20. Receitas líquidas do milho "safrinha" devido à variações nos custos totais de produção e preços do produto, em semeaduras no período de janeiro a maio, em 24 anos de simulações para Londrina e Ponta Grossa, no cenário sem irrigação. 
Em Londrina observa-se, também, que para todas as condições de variações assumidas, os valores médios de receita líquida foram sempre positivos, já para Ponta Grossa, ocorre uma alteração no período de receitas liquidas negativas, principalmente quando os custos são reduzidos em $20 \%$ ou quando é adotado o valor máximo do preço de comercialização.

Fazendo uma análise mais detalhada dos valores médios de rendimentos da Figura 4.14, podemos verificar que em Londrina, uma melhoria no manejo do cultivo, tal como, uma complementação com irrigação, pode resultar em aumentos nos valores de rendimento em todas as épocas de semeadura, o que parece não ser possivel em Ponta Grossa para a maioria das épocas de semeadura, já que nesta, os rendimentos obtidos aproximaram-se consideravelmente dos valores potenciais. Sendo assim alternativas de implementação de manejo (irrigação) serão testadas apenas para Londrina.

Como a irrigação é uma prática que poderá conduzir a atividade agrícola a níveis de rendimentos altos e mais estáveis, seus benefícios econômicos deverão ser estabelecidos, principalmente em regiões úmidas como as deste estudo, devido às diferentes respostas em termos de rendimento e ao alto custo envolvido na implantação e manejo dos sistemas. Isto poderá ser realizado comparando as receitas liquidas considerando a cultura irrigada e não irrigada.

\subsection{SIMULAÇÕES PARA O CENÁRIO SOB IRRIGAÇÃO}

No cenário de manejo com irrigação considerou-se 5 diferentes estratégias de manejo associadas à níveis de água disponível no solo para iniciar a irrigação, como descrito em materiais e métodos, sendo as simulações realizadas para as mesmas datas de plantio do cenário sem irrigação. No caso dos decêndios que não foi possível o estabelecimento da cultura no cenário sem irrigação, devido a falta de umidade no solo, considerou-se, neste cenário sob irrigação, que este problema fora contornado com a aplicação de irrigação antes 
da semeadura, assumido, então, que a mesma fora realizada no ultimo dia do decêndio considerado. Assim, as falhas no estabelecimento e os estresses decorrentes de déficit hídricos foram minimizados com a complementação da irrigação, sendo então as diferenças de rendimento em relação à produção potencial decorrentes dos estresses térmicos e de deficiências de nitrogênio.

\subsubsection{ASPÉCTOS FENOLÓGICOS NO CENÁRIO SOB IRRIGAÇÃO}

As durações dos estádios e ciclo total não apresentaram variações significativas $(\alpha=0,05)$ entre os cenários com e sem irrigação, devido ao fato de que o desenvolvimento de fases no modelo é dependente principalmente da temperatura e não responde a variações da umidade do solo, decorrente da irrigação, como já visto na analise de sensibilidade.

\subsubsection{RENDIMENTO DE GRÃOS NO CENÁRIO SOB IRRIGAÇÃO}

Os valores médios das simulações de rendimento para os cenários sem irrigação, de manejo da irrigação e de produção potencial do milho "safrinha" (cultivar XL-520) em Londrina e Ponta Grossa, para as épocas de semeadura no periodo de janeiro a maio, em 24 anos de simulação (1976 a 1999), com o modelo CERES-Maize, são mostrados na Figura 4.21.

Observa-se que os valores médios de rendimento para os tratamentos com irrigação apresentaram-se bastante próximos uns dos outros ao longo de todas as épocas de semeadura, em ambos os locais, sendo que o tratamento de iniciar a irrigação com $90 \%$ de água disponível no solo apresentou em média resultados de rendimento um pouco inferiores aos demais, principalmente em Londrina, o que é justificado pelo fato de ocorrer uma maior perda de nitrogênio pela lixiviação, devido a maior frequência de irrigação e ocorrência de chuvas 
logo após as irrigações, não possibilitando que o solo pudesse reter toda a água recebida, gerando um volume maior de escoamento superficial e de água drenada pelo perfil do solo explorado pelas raízes das plantas, lixiviando mais intensamente o nitrogênio (ver valores médios do balanço hídrico em anexos). Verificou-se maiores valores do fator de estresse de nitrogênio quando a cultura foi irrigada com maior frequência e estresses hídricos devido a menor velocidade de absorção de água no tratamento de iniciar a irrigação com $10 \%$ de AD no solo. O tratamento de iniciar a irrigação a $50 \%$ de água disponível no solo foi o que proporcionou os maiores rendimentos médios na maioria das épocas de semeadura tanto em Londrina, quanto em Ponta Grossa.

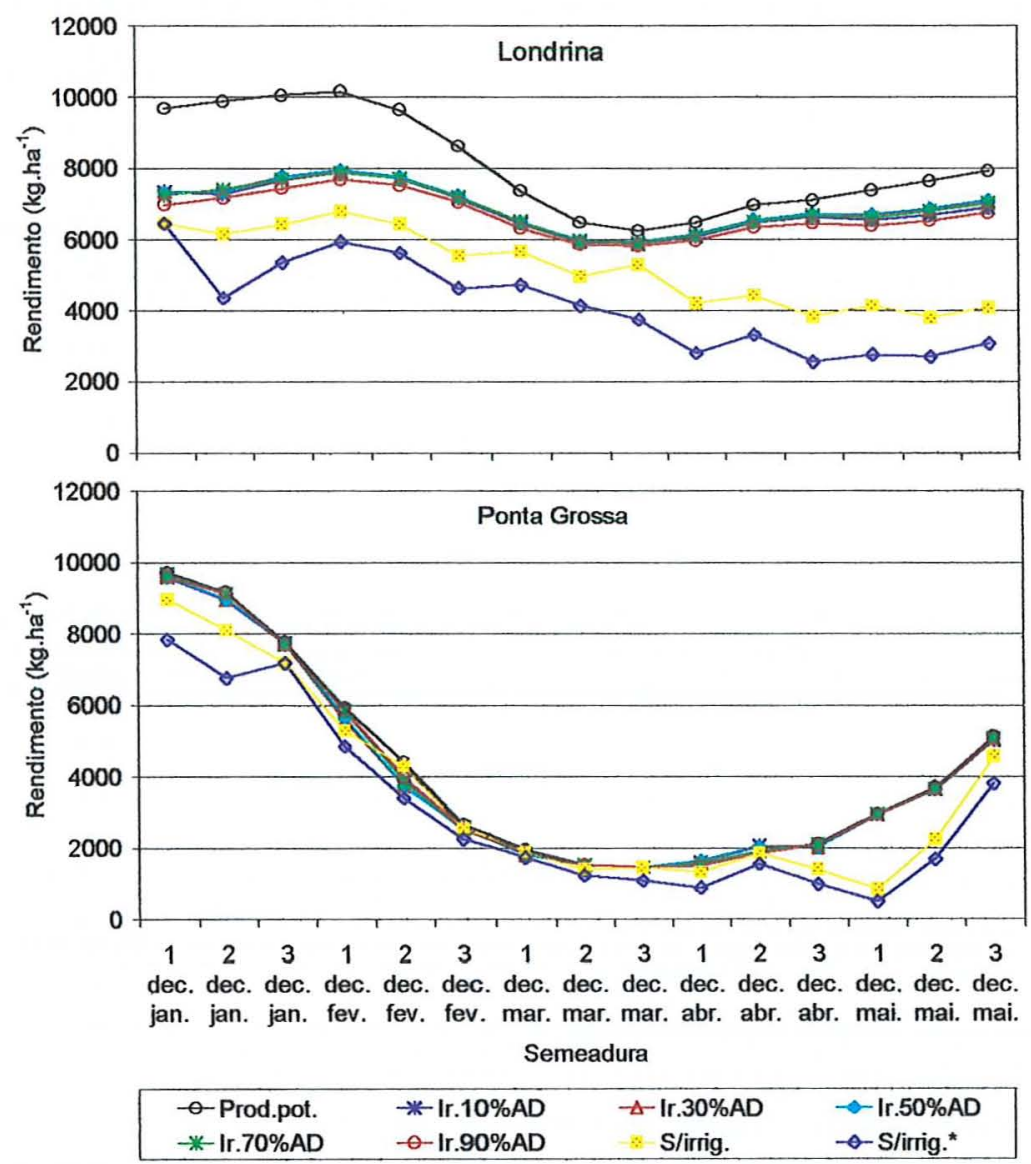

Figura 4.21. Rendimentos médios dos cenários de produção potencial, sem irrigação e com irrigação em diferentes níveis críticos de umidade do solo, de acordo com diferentes épocas de semeadura de milho em Londrina e Ponta Grossa. (Obs. S/irrig. * corresponde a valores médios incluindo as falhas no estabelecimento e safras nulas) 
O incremento nos rendimentos simulados devido ao efeito da irrigação tendeu a ser maior à medida que se atrasou a semeadura em Londrina, principalmente a partir de abril, devido a menor disponibilidade de água no solo decorrente de menores chuvas nesta época, resultando em maior déficit hídrico no cenário sem irrigação que ocorre na média dos anos no período de outonoinverno.

Verificou-se que a irrigação em Londrina proporcionou aumentos notáveis nos rendimentos médios em todas as épocas de semeadura, apresentando os maiores acréscimos a partir de abril. Em Ponta Grossa a irrigação só proporcionou aumentos consideráveis nos rendimentos médios nas semeaduras do mês de janeiro e a partir do $3^{\circ}$ decêndio de abril, sendo assim, a prática da irrigação será analisada mais detalhadamente apenas em Londrina.

Se considerarmos as falhas no estabelecimento como sendo rendimento nulo para o calculo do rendimento médio do cenário sem irrigação (curva azul tracejada, sem irrigação*), a diferença entre rendimentos nos cenários fica ainda mais evidente (Figura 4.21).

Os menores rendimentos médios nos tratamentos com irrigação em Londrina ocorreram nas semeaduras do $3^{\circ}$ decêndio de março, ficando em torno de $6000 \mathrm{~kg} \cdot \mathrm{ha}^{-1}$, e os maiores rendimentos médios no $1^{\circ}$ decêndio de fevereiro, em torno de $8000 \mathrm{~kg} \cdot \mathrm{ha}^{-1}$. Em Ponta Grossa, os menores rendimentos médios com irrigação ocorreram também na semeadura do $3^{\circ}$ decêndio de março, sendo aproximadamente $1450 \mathrm{~kg}^{-h^{-1}}$, e os maiores rendimentos médios no $1^{\circ}$ decêndio de janeiro, em torno de $9600 \mathrm{~kg}_{\text {.ha }}{ }^{-1}$, sendo superior até mesmo ao de Londrina nesta época que ficou em torno $7300 \mathrm{~kg} . \mathrm{ha}^{-1}$.

Os resultados da análise de sensibilidade do cenário com irrigação são apresentados nas Figuras 4.22 e 4.23. Observa-se que as alterações nos valores de radiação solar resultaram em variações regulares nos rendimentos para todos os níveis de irrigação, tendendo a aproximá-los dos rendimentos potenciais quando os valores de radiação foram reduzidos em $20 \%$. O aumento de $20 \%$ na radiação solar deixa mais evidente os menores rendimentos para a 
irrigação iniciando a $90 \%$ de $A D$ no solo. Isto pode ser atribuído à maior demanda por nitrogênio para a produção de fotoassimilados devido à intensificação do metabolismo da planta influenciado pelo aumento da radiação o que foi menos atendido neste tratamento, devido a maior lixiviação do $\mathrm{N}$ no solo.

As variações $(-20 \%$ e $+20 \%)$ nos valores de temperatura do ar apresentaram resultados de rendimentos bastante distintos, ora aumentando e ora diminuindo os rendimentos, com as mesmas respostas ocorridas nos rendimentos do cenário potencial, principalmente quando a temperatura foi acrescida em $20 \%$, sendo que no caso de decréscimos de $20 \%$ nos valores de temperatura,

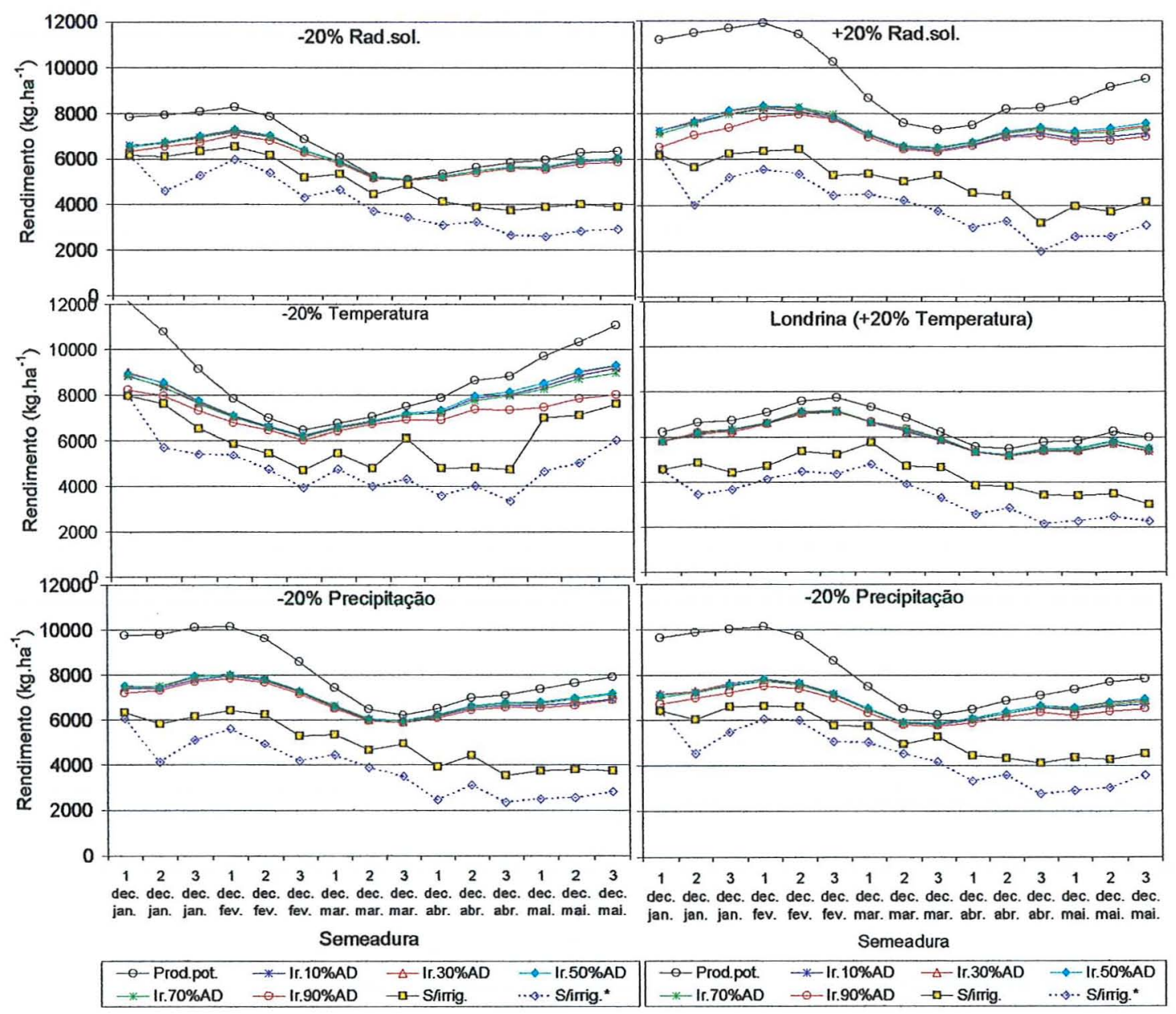

Figura 4.22. Rendimentos médios do milho "safrinha" sem irrigação, para os níveis de irrigação e produção potencial em semeaduras no período de janeiro a maio para Londrina devido a variações nos elementos meteorológicos. 

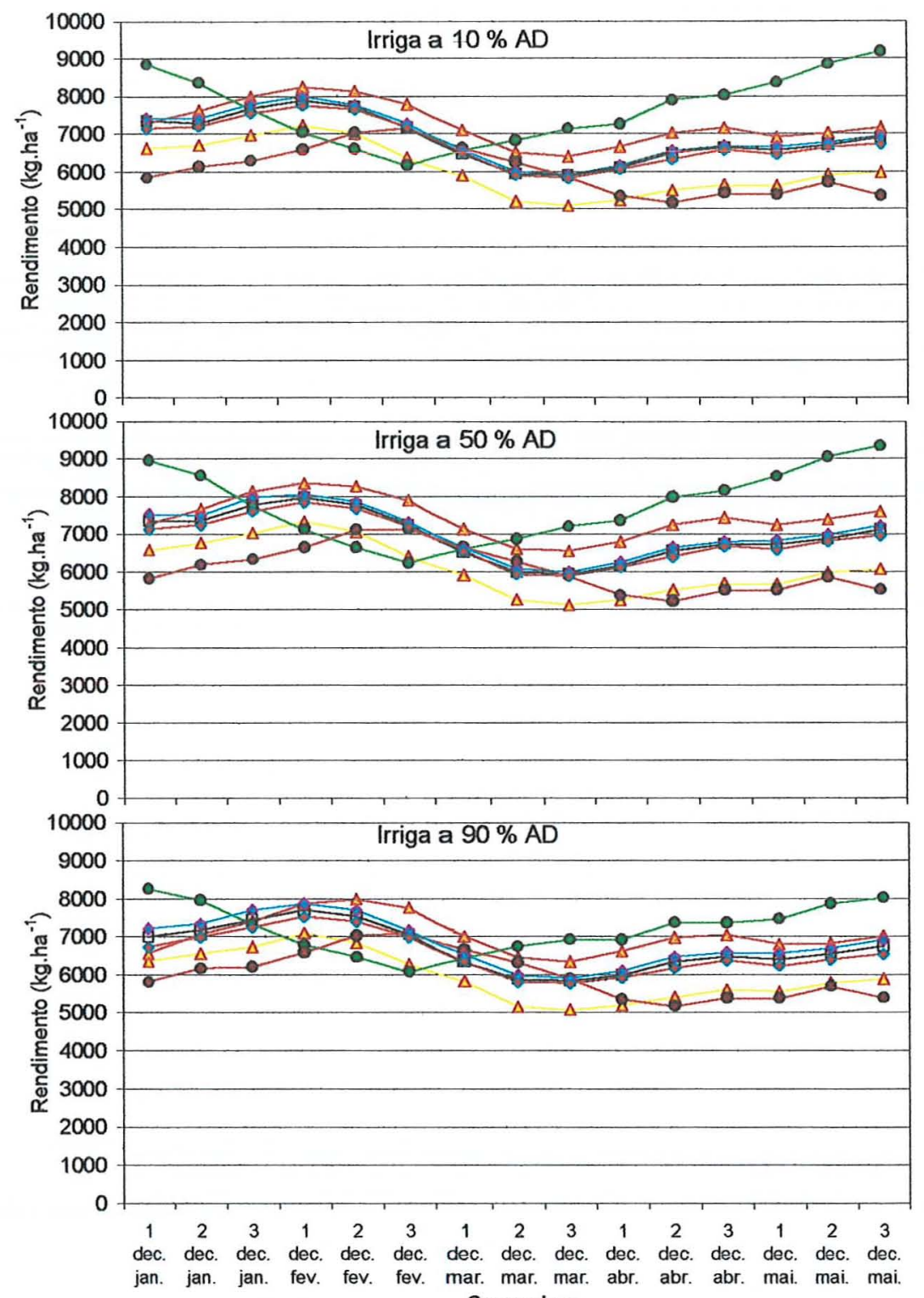

Semeadura

$\begin{array}{|lll|}-\square-\text { sem variaçãol } & \Delta-20 \% \text { rad. solar } & -+20 \% \text { rad. solar } \\ --20 \% \text { temperatura } & -++20 \% \text { temperatura } & --20 \% \text { precipitação } \\ -+20 \% \text { precipitação } & & \end{array}$

Figura 4.23. Variação dos rendimentos médios com o manejo da irrigação a 10 , 50 e $90 \%$ de AD para o milho "safrinha" (XL-520) no período de janeiro a maio para Londrina devido a variações nos elementos meteorológicos.

ocorreram maiores diferenças dos rendimentos em relação aos rendimentos potenciais nas semeaduras de janeiro e maio (inicio e final do período de semeaduras analisadas). O decréscimo em $20 \%$ na temperatura em Londrina 
tendeu em aumentar os valores médios de rendimento potencial para semeaduras nos dois primeiros decêndios de janeiro e a partir do $1^{\circ}$ decêndio de março, e tendeu a reduzi-los para as semeaduras nos outros decêndios. Já o aumento em $20 \%$ na temperatura em Londrina tendeu em reduzir os rendimentos médios para a maioria das épocas de semeadura, exceto na semeadura do $2^{\circ}$ decêndio de março. Isto mostra que para o milho safrinha em Londrina, em geral, aumentos de temperatura são mais prejudiciais do que decréscimos, mesmo quando se usou a irrigação. As variações nos valores de chuva resultaram em pouca variação nos rendimentos em à condição sem variação, sendo que o acréscimo em $20 \%$ na chuva evidenciou os menores rendimentos no tratamento de iniciar a irrigação a $90 \%$ de $A D$, devido a intensificação da lixiviação do $\mathrm{N}$ no solo. Observa-se também que a redução nos valores de chuva, faz com que os incrementos de rendimento devido a irrigação sejam maiores, como era de se esperar.

O aumento de $20 \%$ na radiação solar e o decréscimo de $20 \%$ chuva proporcionam maiores incrementos nos rendimentos devidos a irrigação em relação ao cenário sem irrigação.

$\mathrm{Na}$ Figura 4.23 , observa-se que as respostas dos rendimentos em relação às alterações nas variáveis meteorológicas foram bastante semelhantes às respostas obtidas no cenário de produção potencial, porém ocorrendo em patamares de rendimento diferentes, principalmente os do tratamento de $90 \%$ de $A D$ no solo, cujos rendimentos são levemente inferiores aos demais.

$\mathrm{Na}$ Figura 4.24 pode-se verificar que os valores médios de rendimento em Londrina foram bastante semelhantes em cada decêndio, não apresentando diferenças significativas $(\alpha=0,05)$ entre seus valores. $\mathrm{Na}$ análise de variância também verificou-se que em relação ao cenário sem irrigação* (valores médios dos 24 anos de simulação), apenas na semeadura do $1^{\circ}$ decêndio de janeiro, o acréscimo de rendimento devido a irrigação não apresentou diferença significativa ao nivel de $5 \%$ de probabilidade, sendo que quanto mais tardia a semeadura maior foi a diferença nos rendimentos médios entre os cenários. 
Quando comparou-se os rendimentos decorrentes dos tratamentos de irrigação com os rendimentos potenciais, verificou-se que existem diferenças significativas $(\alpha=0,05)$ apenas nas semeaduras dos meses de janeiro e fevereiro.

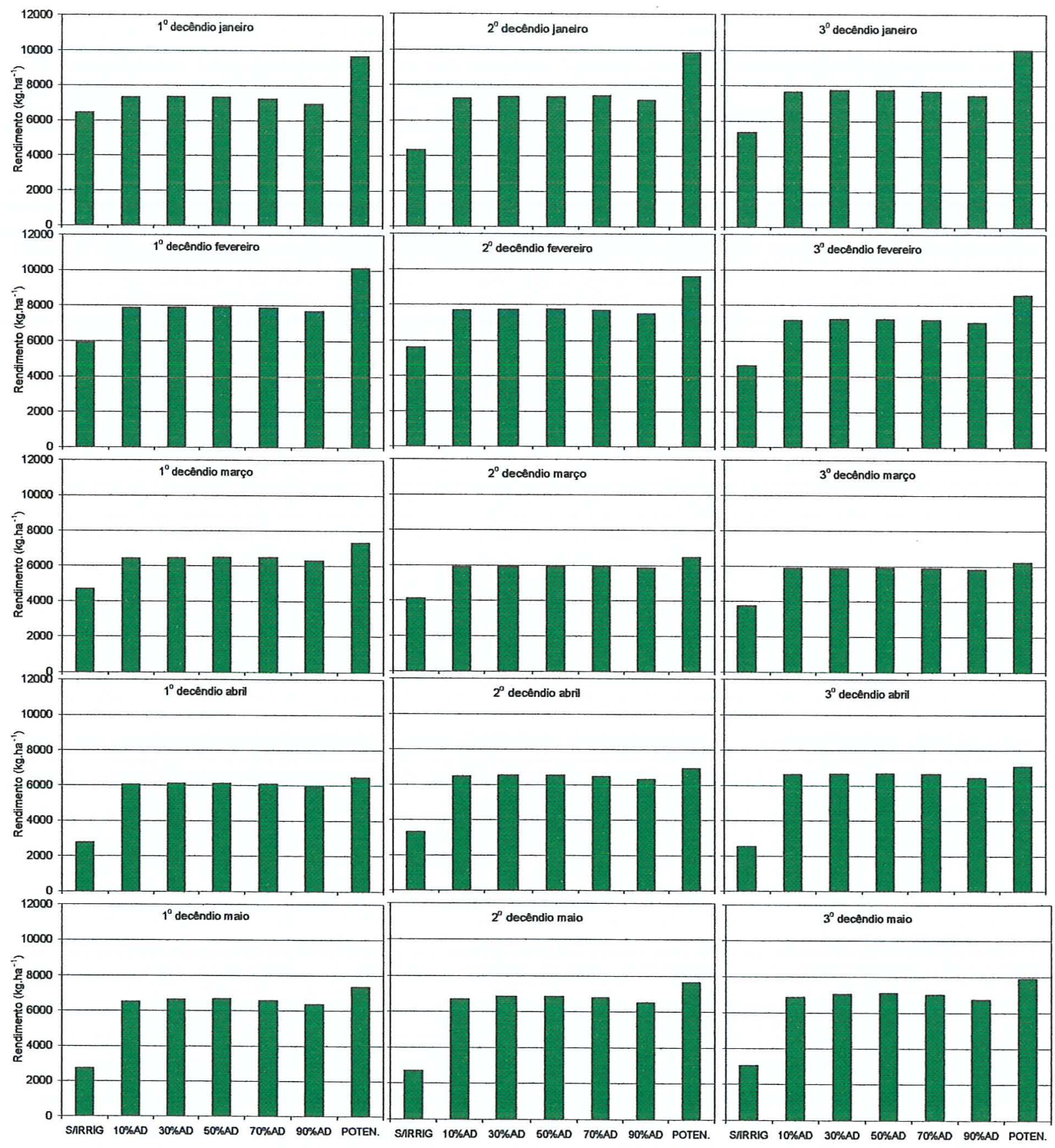

Figura 4.24. Rendimentos médios do milho "safrinha" sem irrigação, para os níveis de irrigação e produção potencial em semeaduras nos 15 decêndios do período de janeiro a maio para Londrina. 
Estas diferenças podem ser atribuidas aos estresses decorrentes da deficiência de nitrogênio, que foi influenciada pela maior lixiviação deste nutriente, devido a maior ocorrência de chuvas neste período de exploração do cultivo do milho "safrinha". Adequadas condições hídricas no solo na média dos anos possibilitam um maior acúmulo de fotoassimilados resultando em altos rendimentos.

Então, tendo sido supridas as necessidades hídricas da cultura pela irrigação, os decréscimos simulados em relação à produção potencial foram atribuídos a deficiências de nitrogênio em Londrina, e ao menor crescimento da cultura causado pela ocorrência de condições climáticas sub-ótimas, principalmente temperaturas mais baixas e a menor disponibilidade de radiação solar em Ponta Grossa. Em Londrina, provavelmente, ocorreu uma maior limitação de nitrogênio o que não permitiu a cultura aproveitar melhor a água suplementada via irrigação, mesmo assim os acréscimos nos rendimentos são bastante significantes em relação ao cenário sem irrigação.

Nota-se que em todos os niveis de irrigação em Londrina os rendimentos foram mais estáveis ao longo do período de exploração do milho safrinha, o que pode ser melhor verificado através das funções de probabilidade acumulada de cada decêndio na Figura 4.25. Na maioria das épocas de semeadura a irrigação apresenta uma dominância estocástica de $1^{\circ} \mathrm{grau}$ em relação ao tratamento sem irrigação ( 9 decêndios), e dominância de $2^{\circ}$ grau nos demais.

O tratamento de iniciar a irrigação com $50 \%$ de água disponivel (AD) no solo apresentou dominância estocástica de $2^{\circ}$ grau na maioria das épocas de semeadura analisadas exceto no $1^{\circ}$ e $2^{\circ}$ decêndios de janeiro, onde a dominância foi do tratamento de iniciar a irrigação com $30 \%$ e $70 \%$ de $A D$ no solo, respectivamente, porém sem apresentar diferença significativa $(\alpha=0,05)$ em relação aos demais tratamentos. $O$ tratamento de irrigação que em geral foi mais dominado correspondeu ao nível de iniciar a irrigação a $90 \%$ de $A D$ no solo, devido a maiores deficiências de nitrogênio.

Observa-se, também, que quanto maior a área compreendida entre as curvas das funções de probabilidade dos rendimentos do cenário sem irrigação 
e dos tratamentos de irrigação maior será a contribuição da irrigação no incremento de produção. A maior contribuição desta prática ocorreu nas semeaduras do $3^{\circ}$ decêndio de abril e a menor contribuição no $1^{\circ}$ decêndio de janeiro.
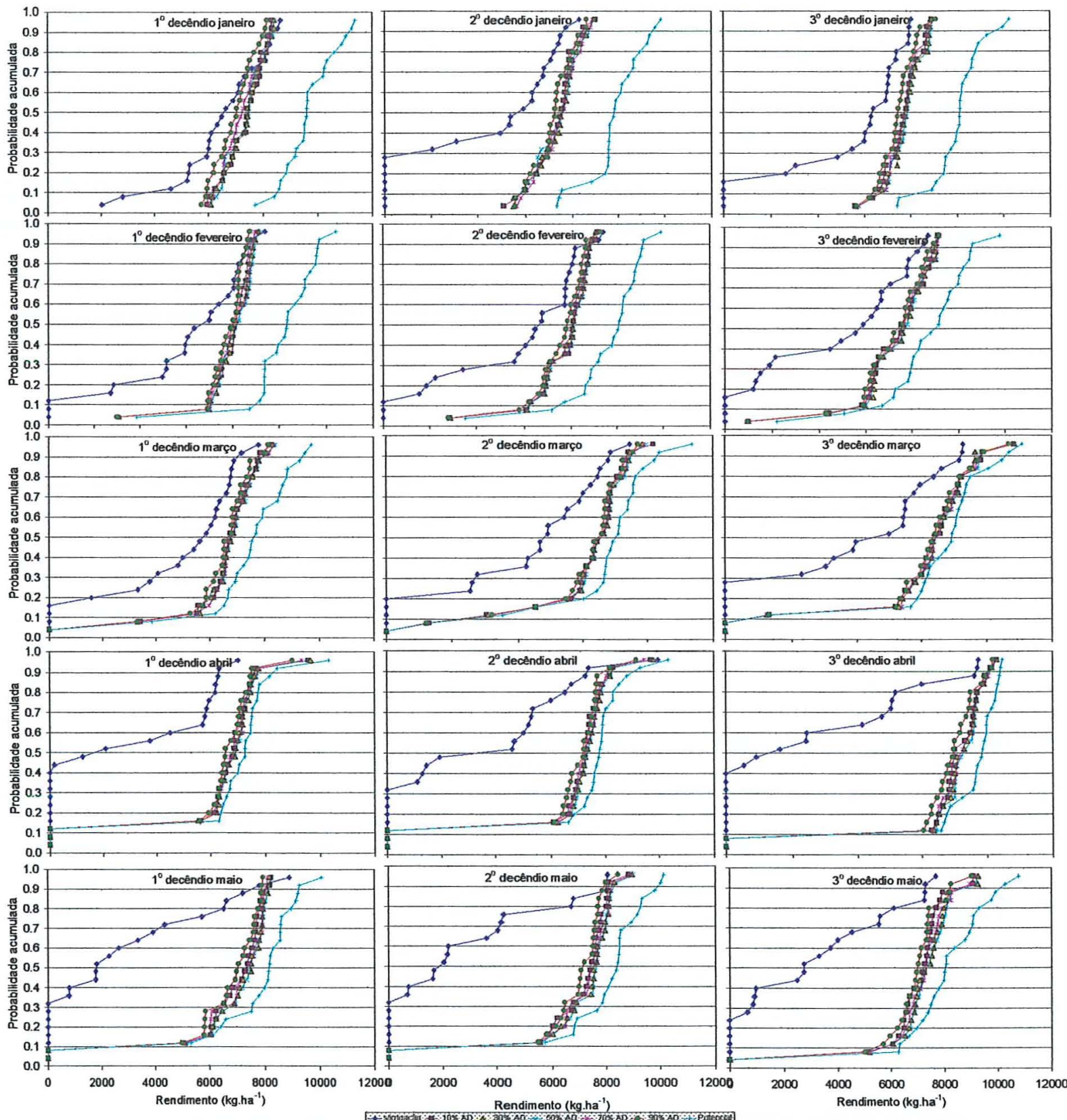

Figura 4.25. Funções de probabilidade acumulada do rendimentos médios do milho "safrinha" sem irrigação, para os níveis de irrigação e produção potencial em semeaduras nos 15 decêndios do período de janeiro a maio para Londrina. 
Observou-se que com a irrigação os riscos de frustrações de rendimento foram minimizados.

Devido a grande variabilidade climática em que os cultivos se defrontam quando semeados em épocas distintas nesta região, principalmente quanto às chuvas e demanda evaporativa da atmosfera, as respostas à irrigação também são bastante diferenciadas, principalmente no que tange a quantidade de água e números de aplicações de irrigação (tabela em anexos), sendo assim, passamos a analisar a viabilidade econômica da irrigação em Londrina para cada época de semeadura aqui consideradas.

\subsubsection{ANALISE ECONÔMICA PARA O CENÁRIO SOB IRRIGAÇÃO}

Muitos estudos mostram que os parâmetros ótimos de irrigação para cada estação são aqueles que maximizam o lucro liquido esperado e nem sempre estão relacionados com a melhor estratégia que maximiza a rendimento físico das culturas, pelo fato de ser a irrigação uma prática de custo relativamente alto, principalmente devido ao alto consumo de energia. Além disso, muitos agricultores são aversos ao risco, e a estratégia ótima neste caso, pode não ser aquela que resulta no maior lucro líquido e nem naquela de rendimento máximo, mas naquela que possibilite um menor risco de sua atividade.

Analisou-se então a viabilidade econômica da implementação da irrigação desta cultivar de milho no período da "safrinha" em Londrina. $\mathrm{Na}$ Figura 4.26 e 4.27 , encontram-se os valores médios das receitas líquidas obtidos para o milho "safrinha" (cultivar XL-520) em Londrina para o cenário de manejo da irrigação, nas 15 épocas de semeaduras, em comparação com o rendimento do cenário sem irrigação. Observa-se que em Londrina, os maiores resultados médios foram obtidos na semeadura do $1^{\circ}$ decêndio de fevereiro $\mathrm{e}$ os menores na semeadura do $3^{\circ}$ decêndio de março, em todos os níveis de irrigação analisados. O tratamento de iniciar a irrigação em $90 \%$ de AD no solo 
é o que resulta em menores receitas líquidas, devido ao fato de necessitar um maior volume de água o que resultou em aumentos consideráveis nos custos de produção. As maiores receitas líquidas no cenário de irrigação foram obtidas no tratamento de iniciar a irrigação em $10 \%$ de $A D$ no solo, devido à menor frequëncia de irrigaçāo, necessitando menores quantidades de àgua, minimizando desta forma os custos totals de produçāo.

Nota-se na Figura $\frac{\pi}{4} 27$, que a medida que aumentou a frequência de irrigaçāo (aumento do nivel de AD para iniciar a irrigaçăo), ou seja, quando aumentou a quantidade de água ministrada via irrigaçäo, as recoitas líquidas foram decrescentes, devido ao aumento dos custos variáveis da irrigação pois estes foram considerados como sendo proporcionais ao volume de água aplicado à cultura $\left(\mathrm{R} \$ \cdot \mathrm{m}^{-3} \cdot h \mathrm{a}^{-1}\right)$. Ao confrontar as receitas líquidas entre os cenários com e sem irrigação, verifica-se que o tratamento sem irrigação proporcionou resultados médios maiores para a semeadura no $1^{\circ}$ decêndio de janeiro e nos 3 decêndios do mês de março e o tratamento de iniciar a irrigação com $10 \%$ de $A D$ no solo foi superior nas semeaduras dos demais decêndios analisados. $O$ tratamento de irrigar com $90 \%$ de ADD no solo propiciou receltas liquidas medias

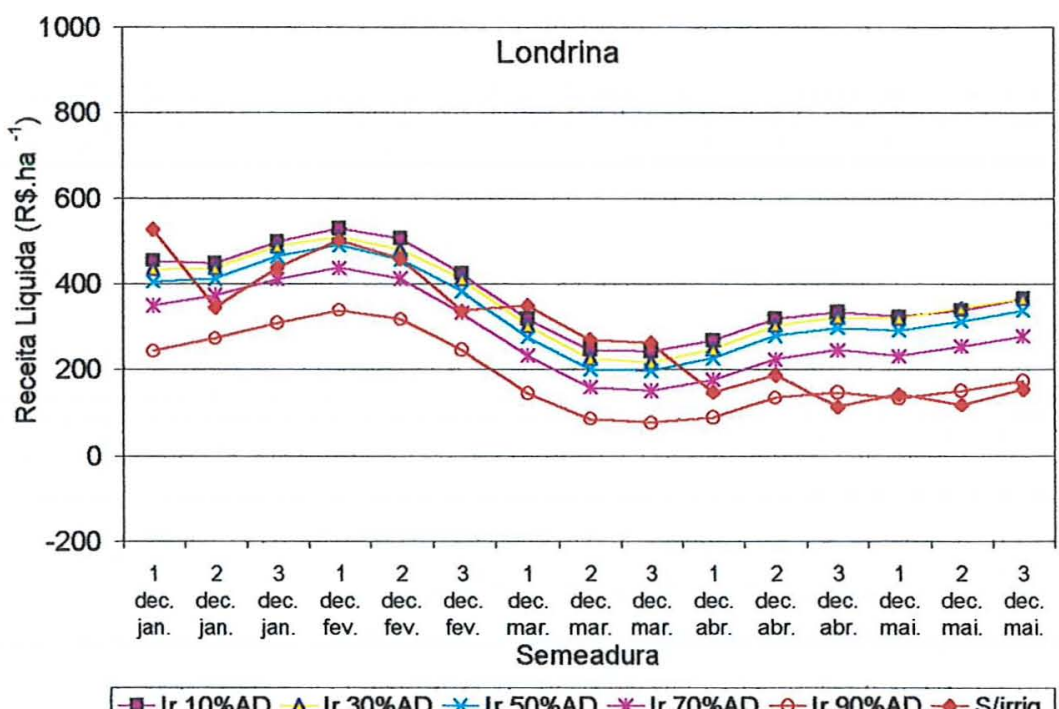

Figura 4.26. Receitas líquidas médias do milho "safrinha" para os cenários sem irrigação e com irrigação, semeado no período de janeiro a maio em 24 anos de simulações para Londrina. 

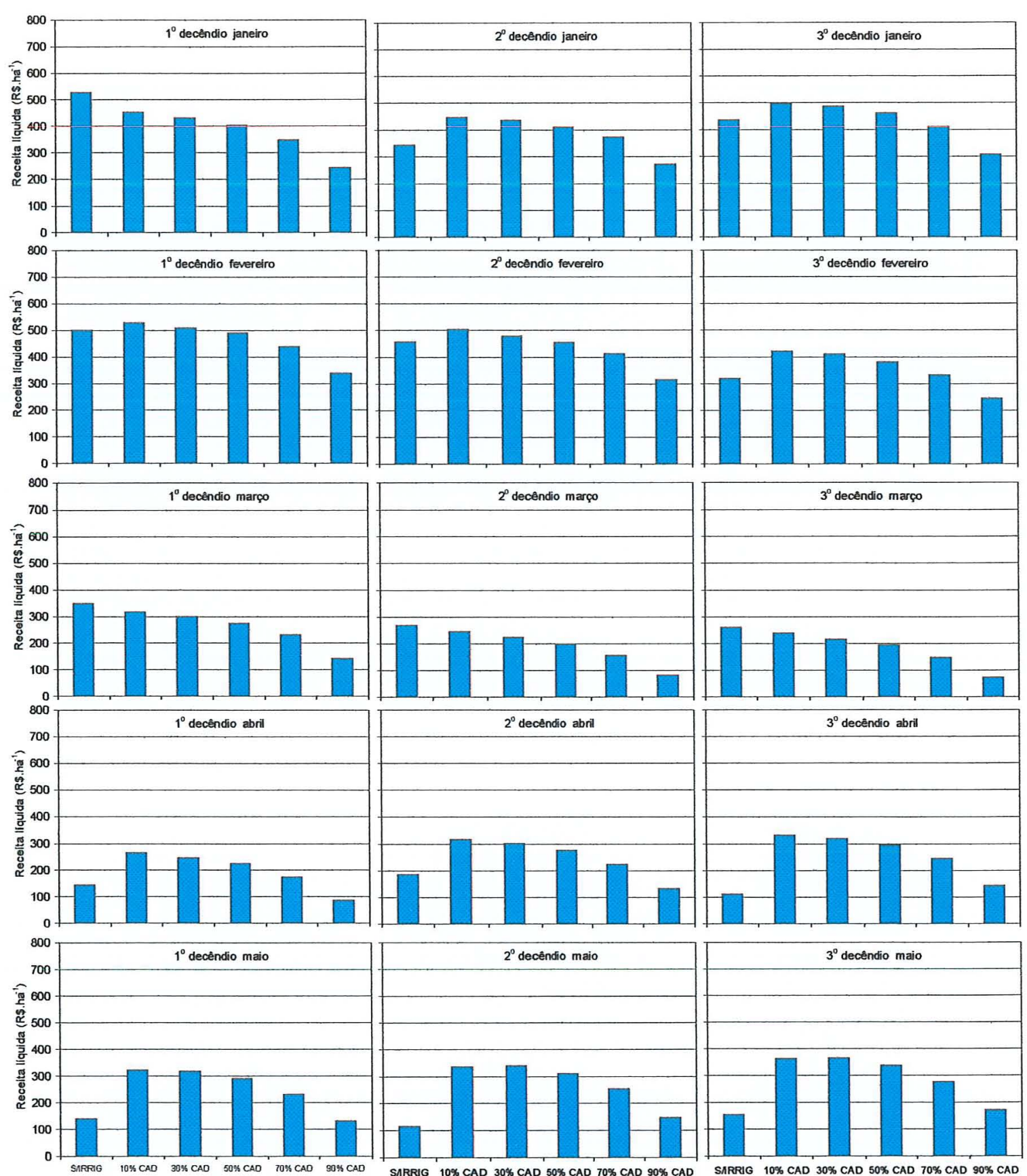

Figura 4.27. Receitas líquidas médias do milho "safrinha" para o cenário sem irrigação e com irrigação, semeado no período de janeiro a maio, em 24 anos de simulações para Londrina.

inferiores ao tratamento sem irrigação na maioria das épocas de semeaduras, exceto no $3^{\circ}$ decendio de abril e nos dos utimos decendios de malo.

Na analise de sensibilidade (Figura 4.28 ), pode-se verificar as respostae 
das receitas líquidas em relação à variações dos custos e preços do produto para o tratamento sem irrigação e para os níveis de irrigação analisados. unserva-se que as respostas a estas variações nos valores das receitas líqui-

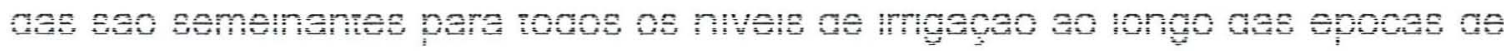

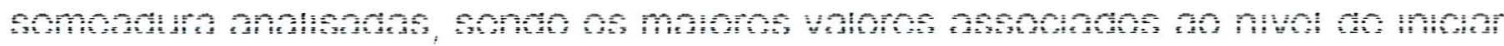
a migacă a $10 \%$ de AD no solo, as menores quando a imigaço iniciar a $90 \%$ de AD no solo. As maiores variações ocorreram quando considerou-se o preço de comercialização igual ao preço máximo e mínimo do produto no período de lyus a lyua corrigdos para dezembro de 1999. Valores médios de receita liqude negame tpreulzos, toram onndas quando o muno rol comerclanzado pelo preço mínimo, ocorrendo a partir da semeadura do $1^{\circ}$ decêndio de março para o nível de iniciar a irrigação a $90 \%$ de $A D$ no solo, e nas semeaduras do $2^{\circ}$ e $3^{\circ}$ decêndios de março para a irrigação a $70 \%$ de $A D$ no solo.
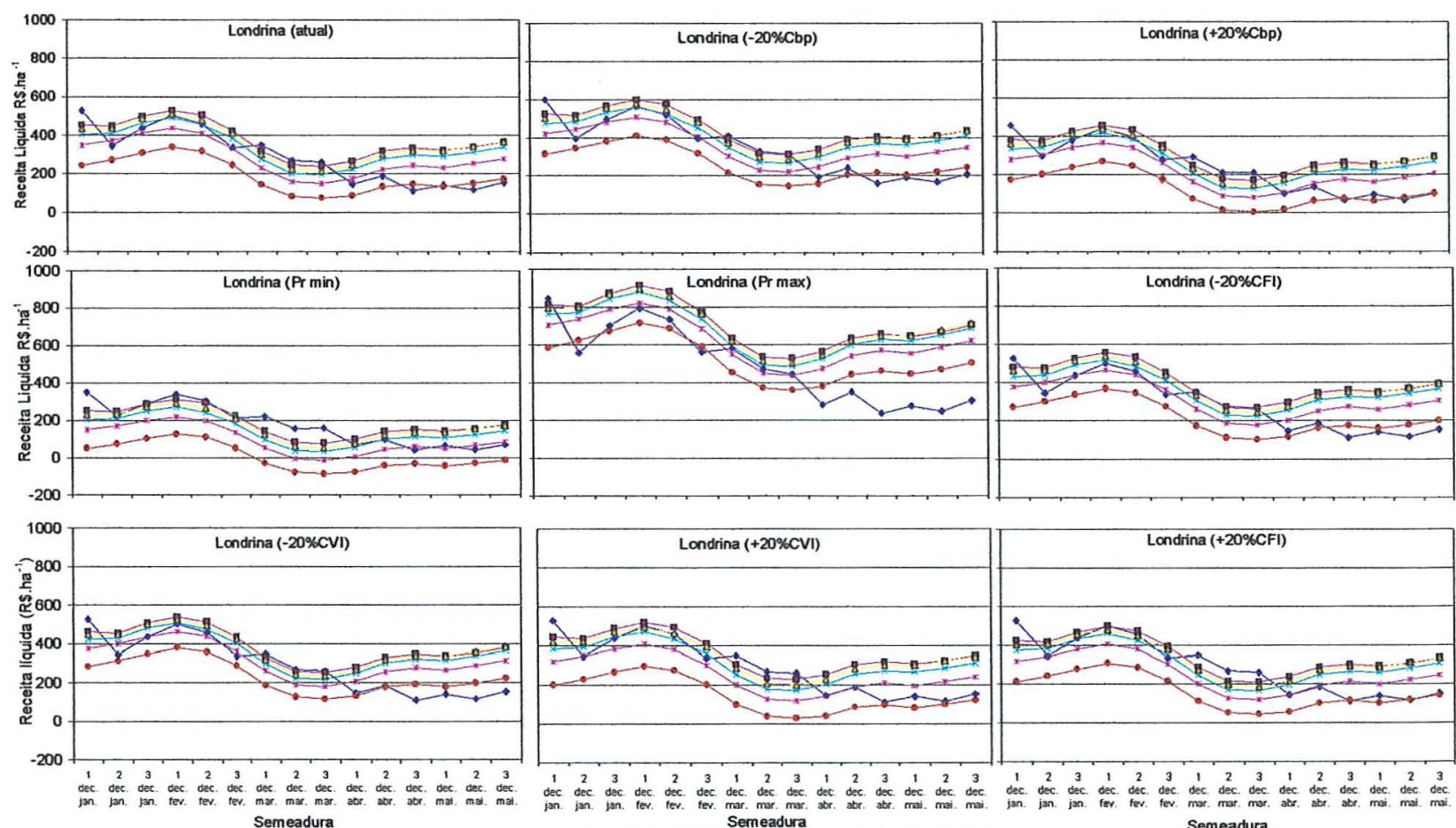

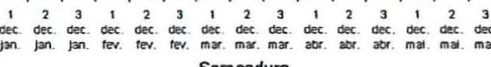

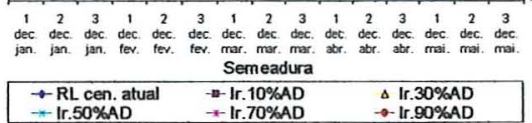

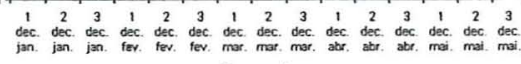

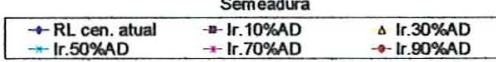

Figura 4.28. Variação da receita Líquida média do milho "safrinha" (cultivar XL520 para o cenário sem irrigação e com irrigação, semeado no período de janeiro a maio, em 24 anos de simulações para Londrina em função das variações nos custos e preços do produto. 
As maiores diferenças entre receitas líquidas dos tratamentos de irrigação em relação ao tratamento sem irrigação ocorreram quando considerou-se o preço máximo de comercialização, sendo que nesta condição a irrigação iniciando à 10 e $30 \%$ de $A D$ no solo resulta em maiores receitas líquidas mesmo nas semeaduras do mês de março.

As variações $(-20 \%$ e $+20 \%)$ nos custos básicos de produção não alteraram o tratamento dominante ao longo dos decêndios, porém a redução dos custos básicos possibilitou maiores incrementos de receita liquida nos tratamentos com irrigação.

Variações nos preços de comercialização foram as que mais influenciaram sobre os tratamentos que se tornam dominantes em cada decêndio.

As variações nos custos fixos e variáveis da irrigação alteram os niveis de receita líquida apenas dos tratamentos de irrigação, sendo as variações nos custos fixos as que proporcionaram maiores alterações nos incrementos de receita líquidas entre os tratamentos com e sem irrigação.

Observou-se que no $1^{\circ}$ decêndio de janeiro o tratamento sem irrigação sempre resultou em maiores receitas líquidas em qualquer das situações.

As funções de probabilidade acumulada das receitas líquidas do milho "safrinha" (cultivar XL-520), semeado nos 15 decêndios de janeiro a maio em Londrina, obtidos a partir das simulações com o modelo CERES-Maize, para a comparação entre as estratégias de irrigação e sem irrigação, são mostrados na Figura 4.29. Nesta Figura observa-se que o tratamento sem irrigação foi dominante em $2^{\mathrm{a}}$ ordem na semeadura do $1^{\circ}$ decêndio de janeiro e nas do mês de março, nestas ultimas principalmente devido aos grandes prejuízos (receitas líquidas negativas) que ocorreram com probabilidade ao redor de 10 a $15 \%$. Nas demais épocas de semeadura, a irrigação iniciando a $10 \%$ de AD no solo foi dominante e a irrigação começando a $90 \%$ de $A D$ foi sempre dominada em todas as épocas de semeadura. Isto pode ser atribuído ao aumento dos custos a medida que um volume maior de água torna-se necessário e por ser o tratamento que resulta em menores rendimentos decorrente de maiores deficiências de ni- 
trogênio. Na semeadura do $3^{\circ}$ decêndio de abril foram obtidos os maiores incrementos nos valores médios de receita líquida com o uso da irrigação. Observase pelas curvas das probabilidades acumuladas que a prática da irrigação possibilita uma malor estabilidade nas receltas liqudas sn todos os decendios

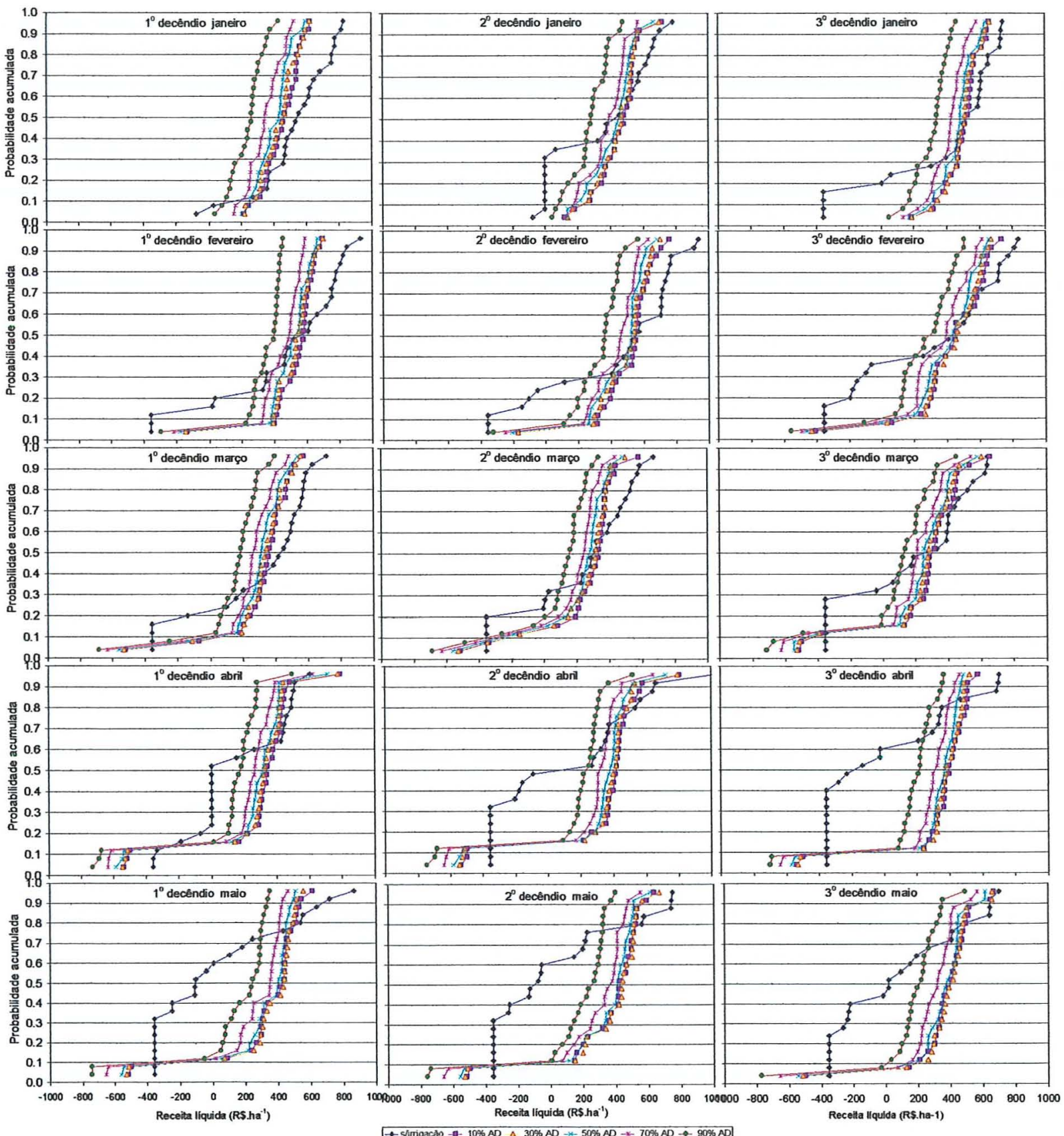

Figura 4.29. Probabilidades acumuladas da receita líquida do milho "safrinha" (cultivar XL-520) semeado no período de janeiro a maio para Londrina, no cenário sem irrigação e sob irrigaça 
com menores riscos de prejuízos na maioria dos decêndios analisados.

Em resumo, vimos, através destas análises, a grande variabilidade nas respostas da cultura quanto aos tratamentos com niveis para iniciar a irrigação nas 15 épocas de semeadura analisadas com a cultivar de milho XL-520 cultivada neste período de análise considerado.

Evidencia-se que para todas as épocas de semeadura, a irrigação proporcionou incrementos significativos nos valores médios de rendimentos desta cultivar, com os valores máximos ocorrendo entre os tratamentos de $30 \%$ a $70 \%$ de $A D$ com uma pequena variabilidade ao longo dos decêndios, porém não apresentando diferenças significativas em relação aos demais.

Os lucros foram maiores para os tratamentos com nivel de iniciar a irrigação com $10 \%$ de $A D$ no solo, devido a seus custos serem menores, decorrentes da menor quantidade de água de irrigação demandada.

A viabilização da irrigação, analisada através da dominância estocástica dos valores de receita líquida, mostrou que a irrigação constituiu-se em uma melhor alternativa para a maioria dos decêndios, exceto para as semeaduras no $1^{\circ}$ decêndio de janeiro e nos 3 decêndios de março, onde o tratamento sem irrigação mostrou uma maior dominância (em $2^{a}$ ordem), porém apresentando um risco maior do que os tratamentos com irrigação, evidenciando que nem sempre a alternativa de maior rendimento físico, seja a mais viável economicamente. No caso dos decêndios de março, mesmo sendo o tratamento sem irrigação a opção que apresenta a maior probabilidade de obtenção de lucros, a irrigação torna-se a alternativa mais estável em função de seu menor risco associado, principalmente para o tratamento de $10 \%$ de $A D$, sendo então esta a provável alternativa para um tomador de decisões com aversão ao risco. 


\section{CONCLUSÕES}

As simulações para o milho "safrinha", cultivar XL-520, com o modelo CERES-Maize permitiram concluir que:

As falhas no estabelecimento da cultura aumentaram com o atraso da semeadura, sendo a condição de umidade no solo o fator mais importante.

Em alguns anos os ciclos foram afetados drasticamente por temperaturas bastante baixas durante o florescimento e enchimento de grão.

As durações dos estádios e ciclos simulados tenderam a alongar-se quando confrontados com temperaturas mais baixas.

As durações médias dos ciclos desta cultivar foram maiores em Ponta Grossa (160 dias) do que em Londrina (153 dias), devido a temperaturas mais amenas e menor radiação solar.

O alongamento na duração do ciclo desta cultivar para a exploração na "safrinha" pode atrasar o cultivo da cultura de verão em anos com grande ocorrência de temperaturas baixas, principalmente em semeaduras a partir de março em Ponta Grossa.

Os rendimentos decresceram quando os ciclos se confrontaram com temperaturas mais baixas, menor disponibilidade hídrica e de radiação solar, o que resultou em rendimentos menores em Ponta Grossa, na maioria dos decêndios. Os rendimentos potenciais e os rendimentos do cenário sem irrigação foram maiores em Londrina (em média de $8100 \mathrm{~kg} \cdot \mathrm{ha}^{-1}$ e $5305 \mathrm{~kg} \cdot \mathrm{ha}^{-1}$, respectivamente) do que em Ponta Grossa (em média de $4075 \mathrm{~kg} \mathrm{ha}^{-1}$ e $3725 \mathrm{~kg}$.ha ${ }^{-1}$ ), devido a diferenças nos solos e principalmente nos elementos do clima. 
Em Ponta Grossa a exploração desta cultivar, além do mês de janeiro, com o nível de manejo estabelecido neste estudo, não seria viável mesmo para as semeaduras com a receita liquida positiva, devido ao alto risco de frustrações de safras associadas às mesmas, decorrentes das condições térmicas.

Nas semeaduras do mês de janeiro os valores esperados de rendimento são maiores em Ponta Grossa do que em Londrina, porém altas probabilidades de prejuízos estão associadas com a maioria das épocas de semeadura, e em Londrina a probabilidade de prejuizos é bem menor e os valores médios de receita líquida foram sempre positivos.

No cenário sem irrigação as maiores receitas líquidas médias ocorreram associadas as semeaduras de fevereiro em Londrina $\left(R \$ 500 \mathrm{ha}^{-1}\right)$ e janeiro em Ponta Grossa (R\$860 ha $\left.{ }^{-1}\right)$.

A irrigação em Londrina constituiu-se em uma alternativa viável pois elevou notoriamente os niveis de rendimento em todas as épocas de semeadura, variando em média entre 6000 a $8000 \mathrm{~kg} \cdot \mathrm{ha}^{-1}$, e reduziu os riscos de estabelecimento e frustração de safra para esta cultivar. Em todos os níveis a irrigação resultou em rendimentos mais estáveis ao longo de todo o período de análise, apresentando dominância de $1^{\circ}$ e $2^{\circ}$ grau em relação a condição sem irrigação, exceto no $1^{\circ}$ decêndio de janeiro.

Os lucros foram maiores com o nível crítico de $10 \%$ de $A D$ no solo, devido a seus custos serem menores, decorrentes da menor quantidade de água demandada. Iniciar a irrigação a $50 \%$ de $A D$ no solo proporcionou os maiores rendimentos médios na maioria das épocas de semeadura, e a irrigação iniciando com $90 \%$ de $A D$ no solo apresentou os menores rendimentos médios devido a maior deficiência de $\mathrm{N}$, decorrente da maior lixiviação deste nutriente no solo.

A irrigação foi a alternativa que resultou em maiores valores médios de receita líquida para a maioria das épocas de semeadura analisadas e nos casos em que a irrigação não apresentou os maiores valores médios de receita 
líquida, a mesma associou-se a menores riscos de prejuízos, reduzindo as falhas de estabelecimento e frustrações de safras.

$O$ incremento nos rendimentos simulados devido ao efeito da irrigação foi maior a partir de abril, devido a menor ocorrência de chuvas nesta época.

A irrigação em Ponta Grossa só proporcionou aumentos notáveis nos rendimentos médios nas semeaduras do mês de janeiro e a partir do $3^{\circ}$ decêndio de abril.

Em Londrina a irrigação intensificou as deficiências de $N$, principalmente em janeiro e fevereiro, devido a sua maior lixiviação o que não permitiu a cultura aproveitar melhor a água complementada via irrigação, mesmo assim os acréscimos nos rendimentos foram bastante significativos em relação ao cenário sem irrigação.

A medida que aumentou a frequência de irrigação as receitas líquidas foram decrescentes, devido ao aumento dos custos variáveis da irrigação, então, não irrigar nas semeaduras do inicio de janeiro e no mês de março e irrigar a $10 \%$ de $A D$ no solo nas demais épocas de semeadura resultaram em maiores receitas líquidas, sendo que a irrigação possibilitou uma maior estabilidade nas receitas líquidas em todos os decêndios com menores riscos de prejuizos na maioria das épocas de semeadura analisadas.

$O$ modelo CERES-maize mostrou-se sensivel quanto as respostas às variações dos principais elementos climáticos.

Este modelo mostrou-se bastante eficiente nas simulações visando a obtenção de dados para atingir os objetivos propostos neste estudo, provando ser uma ferramenta valiosa na tomada de decisões. A condução deste tipo de análise com dados diretamente do campo seria técnica e economicamente inviável, o que vem a salientar a aplicabilidade da simulação em estudos desta natureza. 


\section{REFERÊNCIAS BIBLIOGRÁFICAS}

ALGOZIN, K.A.; BRALTS, V.F.; RITCHIE, J.T. Irrigation strategy selection based on crop yield, water, and energy use relationships: A Michigan example. Journal of Soil and Water Conservation. September-October. p.428-431, 1988.

ALLEN, W.H., \& LAMBERT, J.R. Application of the principle of calculated risk to scheduling of supplemental irrigation. I. Concepts. Agricultural Meteorology. 8:193-201, 1971a.

ALLEN, W.H., \& LAMBERT, J.R. Application of the principle of calculated risk to scheduling of supplemental irrigation. II. Use on Fluecured Tobacco. Agricultural Meteorology. 8:325-340. 1971a.

ARIAS, E.R.A.; OLIVEIRA, M.D.X. de \& ARIAS, S.M.S. Avaliação de cultivares de milho no Estado de Mato Grosso do Sul: resultados do ano agricola 1996/1997. Campo Grande (MS), EMPAER - MS, 1997. 40p.

BAETHGEN, W. Uso de modelos de simulacion en manejo y fertilidad de suelos. In: Curso de atcualizacion técnica manejo y fertilidad de suelos, 2. Uruguay: INIA La Estanzuela. Cap.1, p.4-10. 1995.

BARFIELD, B.J.; PALMER, W.J. \& HAAN, C.T. Simulating the economics of supplemental irrigation for corn. In: RAPER JR, C.D. \& KRAMER, P.T. (eds).

Crop Reactions to Water and Temperature Stress in Humid, Temperature Climates. Westview Press, Boulder, Colo, 1983.

BOGGESS, W.G., \& RITCHIE, J.T. Economic and risk analysis of irrigation decisions in humid regions. J. Prod. Agric. 1(2):116-122, 1988.

BOGGES, W.G., G.D.LYNNE, J.W. JONES, AND D. P. SWANEY. Risk-return assessment of irrigation decisions in humid regions. South. J. Agric. Econ. 15:135-144. 1983. 
BOOTE, K.J.; JONES, J.W. \& PICKERING, N.B. Potential uses and limitations of crops models. Agronomy Journal. 88:704-716. 1996.

BOWEN, W.T.; JONES, J.W.; CARSKY, R.J.; QUINTANA, J. Evaluation of the nitrogen submodel of CERES-Maize following legume green manure incorporation. Agronomy Journal, v.85, n.1 p.153-159, 1993.

BRUNINI, O. Balanço hídrico em condições de campo para cultivares de milho.

In Congresso Nacional de Milho e Sorgo, 14., Florianópolis, 1982. Resumos.

CARAMORI, P.H.; WREGE, M.S.; GONÇALVES, S.L. Zoneamento da cultura do milho "safrinha" e épocas de semeadura no Estado do Paraná. In: Seminário sobre a cultura do milho "safrinha", 5.,Barretos, 1999. Campinas, Instituto Agronômico, Resumos. p.15-20.

COLEMAN, P.H.; MCCLENDON, R.W. \& HOOK, J.E. Computer Analysis of Soybean Irrigation Management Strategies. Transactions of the ASAE, v.30(2): 417-423. 1987.

Companhia Nacional de Abastecimento (CONAB). Levantamento, Jul/97, 1997. www. conab.gov.br/publicações/indicadores.

Companhia Nacional de Abastecimento (CONAB). Levantamento, Nov/99, 1999. www.conab.gov.br/publicações/indicadores.

COSTA, M.M.G. Aplicação de dois modelos de previsão de safra agrícola para a cultura de milho na microregião de Ribeirão Preto, SP. São Paulo, 1992. 207p. Dissertação (Mestrado) - Instituto Astronômico e Geofísico, USP.

CORREIA, L.A.; CRUZ, J.C. \& PEREIRA FILHO, I.A. Avaliação de cultivares de milho para a "safrinha" na região centro-sul. In: Seminário sobre a cultura do milho "safrinha", 4., Londrina, 1997. Resumos. p.135-139.

DIAS, H.S.; BALHESTERO, J.A.V.; VETULLO, D. \& GUTIERREZ, L.S.D. Época da semeadura do milho "safrinha" em função da colheita da soja. In: Seminário sobre a cultura do milho "safrinha", 4., Londrina, 1997. Resumos. p. $57-60$. 
DUARTE, A.P.; KANTHACK, R.A.D; SPINOSA, W. \& ALLIPRANDINI, L.F. Efeito da geada na produção e qualidade de grãos de milho In: Seminário sobre a cultura do milho "safrinha", 3., Assis, 1995. Resumos. Campinas. IAC/CDV. p.61-64.

DUARTE, A. P.; ALLIPRANDINI, L.F. SAWAZAKI, E.; KANTHACK, R.A.D.; ADOANAI, J.; CASTRO, J.L. de, GARCIA, L.C.; PAVÃO, L.A.; NALOTO, A.; FRANCO, J. \& GELLER, C. Avaliação de cultivares de milho "safrinha" no vale do Paranapanema. In: Seminário sobre a cultura do milho "safrinha", 4., Londrina, 1997. Resumos. p.147-151.

FAEDO, F. "Safrinha" de milho: umas realidade no sudeste de Goiás. In: Seminário sobre a cultura do milho "safrinha", 5.,Barretos, 1999. Campinas, Instituto Agronômico, Resumos. p.1-4.

FARIA, R.T. \& CARAMORI, P.H. Precipitação mínima para semeadura do trigo no norte do Paraná. Revista Brasileira de Agrometeorologia, Santa Maria, v.4, n.1, p119-126, 1996.

FARIA, R.T.; OLIVEIRA, D.; FOLEGATTI, M.V. Simulação da fenologia e produção do feijoeiro pelo modelo BEANGRO. In: Congresso Brasileiro de Agrometeorologia, 10., Piracicaba, 1997. Anais. Piracicaba: SBA. p.140-142. FARIA, R.T.; FOLEGATTI, M.V.; FRIZZONE, J.A; SAAD, A M. Determination of a long-term optimal irrigation strategy for dry beans in Parana State, Brazil. Sciencia Agricola, v. 54 (número especial) p.55-164. 1997.

FNP CONSULTORIA E COMÉRCIO. AGRIANUAL, 1999. Anuário Estatístico da Agricultura Brasileira. São Paulo, 521p.

FNP CONSULTORIA E COMÉRCIO. AGRIANUAL, 2000. Anuário Estatístico da Agricultura Brasileira. São Paulo, 546p.

FRATTINI, J.A. Cultura do milho: instruções sumárias. Campinas, CATI/COT. Garcia, J.C.(1997). Evolução da Área e Produtividade do Milho "Safrinha" por Estado. In: Seminário sobre a cultura do milho "safrinha", 4., Londrina, 1997. Resumos. p. 11-14. 
FRIZZONE, J.A.; BOTREL, T.A.; FREITAS, H.A.C. Análise comparativa dos custos de irrigação por pivô-central em cultura de feijão, utilizando energia elétrica e óleo diesel. Engenharia Rural, v.5, n.1, p.24-53, 1994.

FUNDAÇÃO INSTITUTO AGRONÔMICO DO PARANÁ. Avaliação estadual de cultivares de milho "safrinha" - 1997. Informe da Pesquisa. Londrina, IAPAR. N.125. nov.1997.

FUNDAÇÃO INSTITUTO AGRONÔMICO DO PARANÁ. Avaliação estadual de cultivares de milho "safrinha" - 1998. Informe da Pesquisa. Londrina, IAPAR. N.130. nov.1998.

GARCIA, J.C. Evolução da área e produtividade do milho "safrinha" por estado. In: Seminário sobre a cultura do milho "safrinha", 4., Londrina, 1997. Resumos. p.11-14.

GERAGE, A. C. \& SHIOGA. Avaliação Estadual de Cultivares de Milho "safrinha" - 1998. In: Seminário sobre a cultura do milho "safrinha", 5, Barretos, 1999. Anais. Barretos: CATI/IAC/IEA, 1999. p.113-122.

GODWIN, D.C.; JONES, C.A. Nitrogen Dynamics in Soil-crop Systems. In HANKS, R.J. and RITCHIE, J.T. (Eds.) Modeling plant and soil systems. Agronomy Monograph 31, American Society of Agronomy, Madison, Wisconsin, USA. p.287-321. 1991.

GOMES, J. Estudo de risco para o milho na "safrinha". In: Seminário sobre a cultura do milho "safrinha", 3., Assis, 1995. Resumos. Campinas. IAC/CDV. p. 147-152.

GRODZKI, L.; CARAMORI, P.H.; BOOTSMA, A. OLIVEIRA, D. \& GOMES, J. Riscos de ocorrência de geadas no Estado do Paraná. Revista Brasileira de Agrometeorologia, Santa Maria, 4(1):93-99, 1996.

HARTWIG, E.E. Varietal Development. In CALDWEL, B.E. (ed) Soybens: Improvment, Production and Uses. American Society of Agronomy. Cap.6 p187. 1975.

HOWELL, T.A; COPELAND, K.S.; SCHENEIDER, A. D.: DUSEK, D.A. Sprinkler irrigation management for corn - Southern Great Plains. Transactions of the 
ASAE, v.32, p.147-155. 1989.

HOOGENBOOM, G. DSSAT version 3.5 released. International Consortium for Agricultural Systems Aplications (ICASA) NEWS, n.4. p.2, 1998. HOOGENBOOM, G; JONES, J.W.; WILKENS, P.W.; BATCHELOR, W.D.; BOWEN, W.T.; HUNT, L.A. PICKERING, N.B.; SINGH, U; GODWIN, D.C.; BAER, B.; BOOTE, K.J.; RITCHIE, J.T; WHITE, J.W. Crop models. In: TSUJI, G.Y.; UEHARA, G. AND BALAS. (Ed.) DSSAT v3, Decision support system for agrothechnology transfer. Honolulu: University of Hawai v.2. cap.2, p.95-242, 1994.

IBSNAT (Project). Documentation for IBSNAT crop model input and output files. Version 1.1, for the Decision Support System for Agrotechnology Transfer (DSSAT V2.1). IBSNAT Tech. Rep.5. Dep. of Agronomy and Soil Sci., College of Tropical Agric. And Human Resources, Univ. of Hawaii, Honolulu. 1990 IMMAMURA, D.T. Creating management files to run crop models and document experiments. In: TSUJI, G.Y.; UEHARA, G. AND BALAS. (Ed.) DSSAT v3, Decision support system for agrothechnology transfer. Honolulu: University of Hawai v.2. cap.2, p.111-144, 1994.

JAME, Y.W.; CUTFORTH, H.W. Crop growth models for decision support systems. Canadian Journal of Plant Science, v.76, n.1, p.9-19, 1996.

JONES, C.A. \& KINIRY, J.R. CERES-Maize: A simulation model of maize growth and development. Texas A\&M Univ. Press., College Station, TX. 194p, 1986. KINIRY, J.R. Maize Phasic Development. In: HANKS, J.; RITCHIE, J.T. (Ed.) Modeling Plant and Soil Systems. Madison, Wisconsin: ASA, 31, 1991. Cap.4, p.55-70.

KUNDU, S.S.; SKOGERBOE, G.V. AND WALKER, W.R. Using a crop growth simulation model for evaluating irrigation practices. Agricultural Water Management, 1982. 5: 253-268.

LIMA, M.G. Calibração e validação do modelo CERES-Maize em condições tropicais do Brasil. Piracicaba, 1995. 119 p. Tese (Doutorado) - Escola Superior de Agricultura "Luiz de Queiroz", Universidade de São Paulo. 
LIU, W.T.H.; BOTNER, D.M.; SAKAMOTO, C.M. Aplication of CERES-Maize model to yield prediction of a Brazilian maize hybrid. Agricultural and Forest Meteorology. V.45, n.2, p.299-312, 1989.

MIRANDA FILHO, J.B. Melhoramento do milho visando à tolerância ao frio. In: Seminário sobre a cultura do milho "safrinha", 3., Assis, 1995. Resumos. Campinas. IAC/CDV. p. 49-58.

MOUTINHO, D.A. Escolha de nova tecnologia sob condições de risco: o caso do feijão de corda em Quixadá. Fortaleza. 118p (M.S - Universidade Federal do Ceará) , 1977.

MONTEITH, J. The quest balance in crop modeling. Agronomy Journal, v.88, p.695-695, 1996.

MUNDSTOCK, C.M. Aspectos fisiológicos da tolerância do milho ao frio. In: Seminário sobre a cultura do milho "safrinha", 3., Assis, 1995. Resumos. Campinas. IAC/CDV. p. 147-152.

NICOLETTI.,A. Mercado do milho. In: Seminário sobre a cultura do milho "safrinha", 4., Londrina, 1997. Resumos. p.1-10.

OLIVEIRA, M.D.X. e FORNASIERI FILHO, D. Comparação do método de graus-dia e do número de dias do calendário para estimativa do florescimento masculino do milho "safrinha", em Mato Grosso do Sul. In: Seminário sobre a cultura do milho "safrinha", 5.,Barretos, 1999. Campinas, Instituto Agronômico, Resumos. p.95-102 .

PACHECO, J.A.C. Modelos de decisão na análise econômica de experimentos agrícolas. Piracicaba, 1985. 111p. Dissertação (Mestrado) - Escola Superior de Agricultura Luiz de Queiroz, Universidade de São Paulo.

PIMENTEL GOMES, F. Curso de estatística experimental. 11 ed. São Paulo, Nobel, 1985. 466p.

REICHARDT, K. A água em sistemas agrícolas. 1. Ed. Malone, São Paulo. 178p. 1987

RITCHIE, J.T. Model for predicting evaporation from a row crop with incomplete cover. Water Resource Research. 1985. 8(5):1204-1213.1972. 
RITCHIE, J.T. A user-oriented model of the soil water balance in wheat. In Wheat Growth and Modeling, eds. DAY, W. \& ATKIN, R.K. New York: Plenum Press, 1985

RITCHIE, J.T. Soil water balance and plant water stress. In: TSUJI, G. Y.; HOOGENBOOM, G.; THORTON, P.K. (Ed.) Understanding options for agricultural production. Dordrecht: Kluwer Academic Publishers. P.41-54. 1998.

RITCHIE, J.T.; SINGH, U.; GODWIN, D.C.; BOWEN, W.T. Cereal growth, development and yield. In: TSUJI, G. Y.; HOOGENBOOM, G.; THORTON, P.K. (Ed.) Understanding options for agricultural production. Dordrecht: Kluwer Academic Publishers. p.79-98. 1998.

RITCHIE, J.T.; GODWIN, D.C.; SINGH, U. Soil and weather inputs for the IBSNAT crop models. In. Decision Support System for Agrotechinology Transfer, Las Vegas, 1989. Symposium Proceedings. Honolulu: University of Hawaii, 1990, p.31-45.

SALOMÃO, C.C. Sistema de plantio direto e convencional - um enfoque de análise de decisão. Piracicaba, 1990. 126p. Dissertação (Mestrado) - Escola Superior de Agricultura Luiz de Queiroz, Universidade de São Paulo.

SALVADOR, R.J. Use of Computerized Simulation to Advance Agricultural Research in Developing Countries. Eighth International Congress on Research in Electrical Sciences. Instituto Tecnológico de la Laguna, 20-24, September, 1993, Torreon, Coahuila, México.

SANS, L.M.A. \& SANTOS, N.C. Resposta de cultivares de milho a variações climáticas. Congresso Nacional de Milho e Sorgo, 19. Porto Alegre, 1992.

SARTORI, J.A. Determinantes genético-fisiológicos e elementos de manejo na escolha de cultivares de milho "safrinha". In: Seminário sobre a cultura do milho "safrinha", 4., Londrina, 1997. Resumos. p.31-35.

SILVA, F.O. da. Informações sobre a cultura do milho "safrinha" na fazenda Gil Mesquita em Guaíra (SP). In: Seminário sobre a cultura do milho "safrinha", 5.,Barretos, 1999. Campinas, Instituto Agronômico, Resumos. p.5-6. SOLER, C.T. Uso do modelo CERES-Maize para identificação de caracterís- 
ticas genéticas desejáveis para milho "safrinha" e determinação de práticas adequadas de manejo em condições de risco climático. Piracicaba, 2000. 86p. Dissertação (Mestrado) - Escola Superior de Agricultura Luiz de Queiroz, Universidade de São Paulo.

SWANEY, D.P; MISCHOE, J.W; JONES, J.W; BOGGES, W.G. Using crop models for management impact of weather characteristics on irrigation decisions in soybeans. Transactions of the ASAE, 1983. v.1808-1814.

THORNTON, P.K. HOOGENBOOM, G.; WILKENS, P. W.; JONES, J.W. Analyzing seasonal analysis experiments. In: TSUJI, G.Y; UEHARA, G. AND BALAS. (Ed.) DSSAT v3, Decision support system for agrothechnology transfer. Honolulu: University of Hawai v.2. cap.2, p.23-65, 1994.

TSUNECHIRO, A. \& OKAWA, C. Perspectivas da safrinha de milho em 1996. Informações Econômicas, São Paulo, 1996. 26(3):87-89.

TSUNECHIRO, A. \& ARIAS, E.R.A. Perspectivas de rentabilidade do milho "safrinha" nas principais regiōes produtoras. In: Seminário sobre a cultura do milho "safrinha", 4., Londrina, 1997. Resumos. p. 15-20.

TSUNECHIRO, A. Milho. In: Prognóstico Agrícola. São Paulo: IEA, v.2, p.233-240. 1998.

TSUNECHIRO, A. Análise do risco da produção e do mercado de milho "safrinha". In: Seminário sobre a cultura do milho "safrinha", 5, Barretos, 1999. Anais. Barretos: CATI/IAC/IEA, 1999. p.127-132.

UEHARA, G \& TSUJI, G. The IBSNAT project. In: PENNING DE VRIES F.W.T., TENG P.S., METSELAAR, K (Ed.) Systems approaches for agricultural development. Kluwer Academic Press, Boston. 505-513. 1993.

VILLALOBOS, F.J. AND FERERES, E.. A simulation model for irrigation scheduling under variable rainfall. American Society of Agricultural Engineers. , 1989. v.32(1):181-188.

WILLIAMS, J.R.; JONES, C.A. \& DYKE, P.T. A modeling approach to determining the relationship between erosion and soil productivity. Transactions of the ASAE. 27(1):129-144.1984. 


\section{ANEXO 1.}

Características físico-hídricas dos solos representativos para Londrina e Ponta Grossa, (Faria, 1997), integrantes do arquivo SOIL.SOL

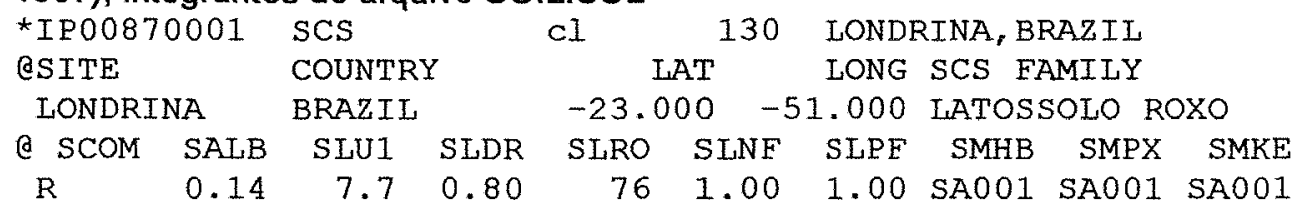

SLB SLMH SLLL SDUL SSAT SRGF SSKS SBDM SLOC SLCL SLSI SLCF SLNI SLHW SLHB

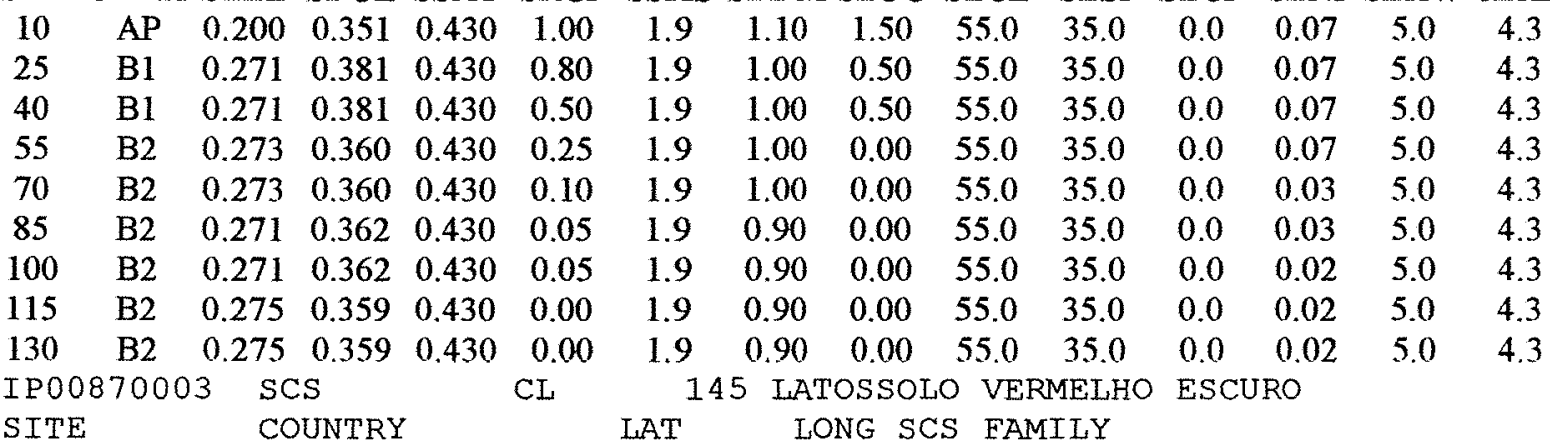

PONTA GROSA BRAZIL; $\quad-25.216 \quad-50.000$

(a) SCOM SALB SLU1 SLDR SLRO SLNF SLPF SMHB SMPX SMKE

$\begin{array}{lllllllll}R & 0.14 & 6.8 & 0.60 & 76 & 1.00 & 1.00 & \text { IB001 IB001 IB001 }\end{array}$

SLB SLMH SLLL SDUL SSAT SRGF SSKS SBDM SLOC SLCL SLSI SLCF SLNI SLHW SLHB

$\begin{array}{cccccccccccccc}10 & 0.240 & 0.351 & 0.430 & 1.00 & 1.9 & 0.99 & 2.75 & 70.0 & 16.0 & 0.0 & 0.70 & 4.6 & -99 \\ 25 & 0.291 & 0.381 & 0.430 & 0.75 & 1.9 & 0.97 & 2.91 & 71.0 & 16.0 & 0.0 & 0.70 & 4.6 & -99 \\ 55 & 0.283 & 0.360 & 0.430 & 0.50 & 1.9 & 0.98 & 1.32 & 73.0 & 16.0 & 0.0 & 0.30 & 4.3 & -99 \\ 85 & 0.271 & 0.362 & 0.430 & 0.20 & 1.9 & 0.97 & 1.30 & 71.0 & 15.0 & 0.0 & 0.30 & 4.3 & -99 \\ 115 & 0.271 & 0.362 & 0.430 & 0.10 & 1.9 & 0.98 & 1.30 & 75.0 & 16.0 & 0.0 & 0.30 & 4.4 & -99 \\ 145 & 0.275 & 0.362 & 0.430 & 0.00 & 1.9 & 0.98 & 1.00 & 71.0 & 15.0 & 0.0 & 0.00 & 4.3 & -99\end{array}$

onde, SCOM

SALB

SLU1

SLDR

SLRO

SLNF

SLPF

SMHB

SMKE

SLB

SLMH

SLLL

SDUL

SSAT

SRGF

SSKS

SBDM

SLOC

SLCL

SLSI

SLCF

SLNI

SLHW

SLHB 


\begin{tabular}{|c|c|c|c|c|c|c|c|c|c|c|c|c|c|c|}
\hline 2 & 76011 & -99 & 5.0 & 5.0 & $S$ & $\mathrm{R}$ & 100 & 0 & 4.0 & -99 & -99 & -99.0 & -99.0 & 0.0 \\
\hline & $\cdots$ & $\cdots$ & $\ldots$ & $\cdots$ & $\cdots$ & $\cdots \cdot$ & ... & ... & $\cdots \cdots$ & ... & $\cdots$ & $\ldots \ldots$ & & \\
\hline 15 & 76143 & $\begin{array}{l}\cdots \\
-99\end{array}$ & 50 & 50 & $\cdots$ & $\cdots$ & in & $\cdots$ & 40 & -99 & -90 & $\begin{array}{ll}\cdots \\
-99 & 0\end{array}$ & -990 & 0.0 \\
\hline \multicolumn{15}{|c|}{ *EERTILIZERS (INORGANIC) } \\
\hline $\mathrm{E}$ & EDATE & EMCD & EACD & EDEP & EAMN & EAMP & EAMK & EAMC & EAMO & EOCD & & & & \\
\hline 1 & 76001 & FE002 & APO02 & 5 & 15 & 0 & 0 & 0 & 0 & & & & & \\
\hline 1 & 76046 & EE002 & APO0 1 & 1 & 40 & 0 & 0 & 0 & 0 & & & & & \\
\hline 2 & 76011 & FE002 & APO02 & 5 & 15 & 0 & 0 & 0 & 0 & & & & & \\
\hline 2 & 76056 & $\mathrm{FE} 002$ & AP001 & 1 & 40 & 0 & 0 & 0 & 0 & & & & & \\
\hline
\end{tabular}

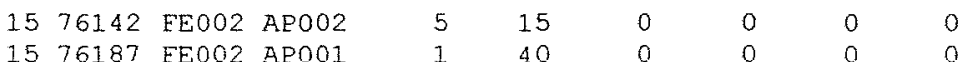

*RESIDUES AND OTHER ORGANIC MATERIALS

$\begin{array}{rrrrrrrrrr}\text { QR RDATE } & \text { RCOD } & \text { RAMT } & \text { RESN } & \text { RESP } & \text { RESK } & \text { RINP } & \text { RDEE } & \text { RMET } \\ 1 & 75355 & \text { RE001 } & 1000 & 0.80 & 0.00 & 0.00 & 100 & 15 & \\ 2 & 76001 & \text { RE001 } & 1000 & 0.80 & 0.00 & 0.00 & 100 & 15 & \end{array}$

$\begin{array}{lllllll}1576132 \text { RED01 } 1000 & 0.80 & 0.00 & 0.00 & 100 & 15\end{array}$

*SIMULATION CONTROLS

QN GENERAL $\quad$ NXERS NREPS START SDATE RSEED SNAME . . . . . . . . . .

1 GE $\quad 24 \quad 1 \quad S 753112150$ NAT.

ON OPTIONS WATER NITRO SYMBI PHOSP POTAS DISES CHEM TILL

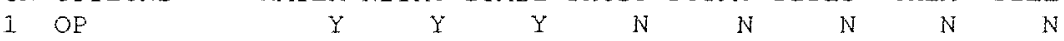

QN METHODS WTHER INCON LIGHT EVAPO INEIL PHOTO HYDRO

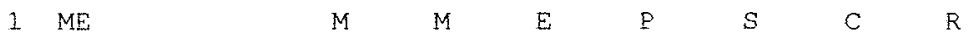

ON MANAGEMENT PLANT IRRIG FERTI RESTD HARVS

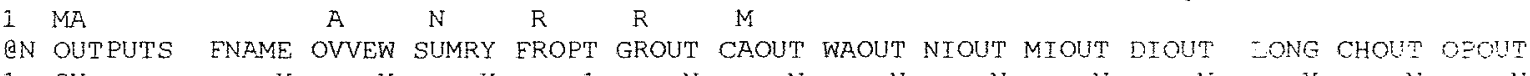
$\begin{array}{llllllllllllllll}1 & \mathrm{~N} & \mathrm{Y} & \mathrm{Y} & \mathrm{Y} & 1 & \mathrm{~N} & \mathrm{~N} & \mathrm{~N} & \mathrm{~N} & \mathrm{~N} & \mathrm{~N} & \mathrm{Y} & N & N\end{array}$ a AUTOMATIC MANAGEMENT

GN PLANTING PERST PLAST PH2OL PH2OU PH2OD PSTMX PSTMN

$1 \mathrm{PL} \quad 7600176010 \quad 50 \quad 100 \quad 10 \quad 40 \quad 10$

ON IRRIGATION IMDEP ITHRL ITHRU IROEF IMETH IRAMT IREEE

1 IR $30 \quad 100 \quad 100$ GSOOO IROOI $-99 \quad 1.00$

GN INITROGEN NMDEP NMTHR NAMNT NCODE NAOEE

1 NI $30 \quad 50 \quad 25$ EEOOI GSOOO

EN RESIDUES RIPCN RTIME RIDEP

1 RE $\quad 100 \quad 1 \quad 20$

ON HARVEST HFRST HLAST HPCNP HPCNR

I HA. O $77006100 \quad 0$

* SIMULATION CONTROLS

CN GENERAL NYERS NREPS START SDATE RSEED SNAME . . . . . . . . .

$15 \mathrm{GE} \quad 24 \quad 1 \quad S \quad S 76086 \quad 2150 \mathrm{NAT}$.

EN OPTIONS WATER NITRO SYMEI PHOSE POTAS DISES CHEM TILL

15 OP

ON METHODS

$15 \mathrm{ME}$ $\begin{array}{llllllll}Y & Y & Y & N & N & N & N & N\end{array}$ WTHER INCON LIGHT EVAPO INEIL PHOTO HYDRO

\&N MANAGEMENT PLANT IRRIG EERTI RESID HARVS

$15 \mathrm{MA}$ A N $\mathrm{N}$ R M

BN OUTPUTS ENAME OVVEW SUMRY EROPT GROUT CAOUT WAOUT NIOUT MIOUT DIOUT IONG CHOUT ODOUT 15 OU $Y$ Y Y Y

QN PLANTING PERST PLAST PHZOL PHZOU PHZOD PSTMX PSTMN

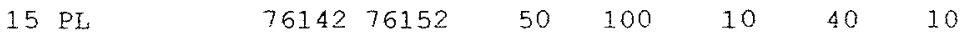

RN IRRIGATION IMDEP ITHRL ITHRU IROFE IMETH IRAMT IREFE

15 IR $30 \quad 100 \quad 100$ GSOOO IROOI -991.00

AN NITROGEN NMDEP NMTHR NAMNT NCODE NAOEF

$15 \mathrm{NI} \quad 30 \quad 50 \quad 25$ FEOO1 GSOOO

ON RESIDUES RIPCN RTIME RIDEP

$15 \mathrm{RE} \quad 100 \quad 1 \quad 20$

QN HARVEST HERST HLAST HPCNP HPCNR

$\begin{array}{llll}15 \mathrm{HA} & 0 & 77006 & 100\end{array}$ 


\section{ANEXO 3}

\section{ARQUIVO DE COEFICIENTES GENÉTICOS (CULTIVAR XL-520)}

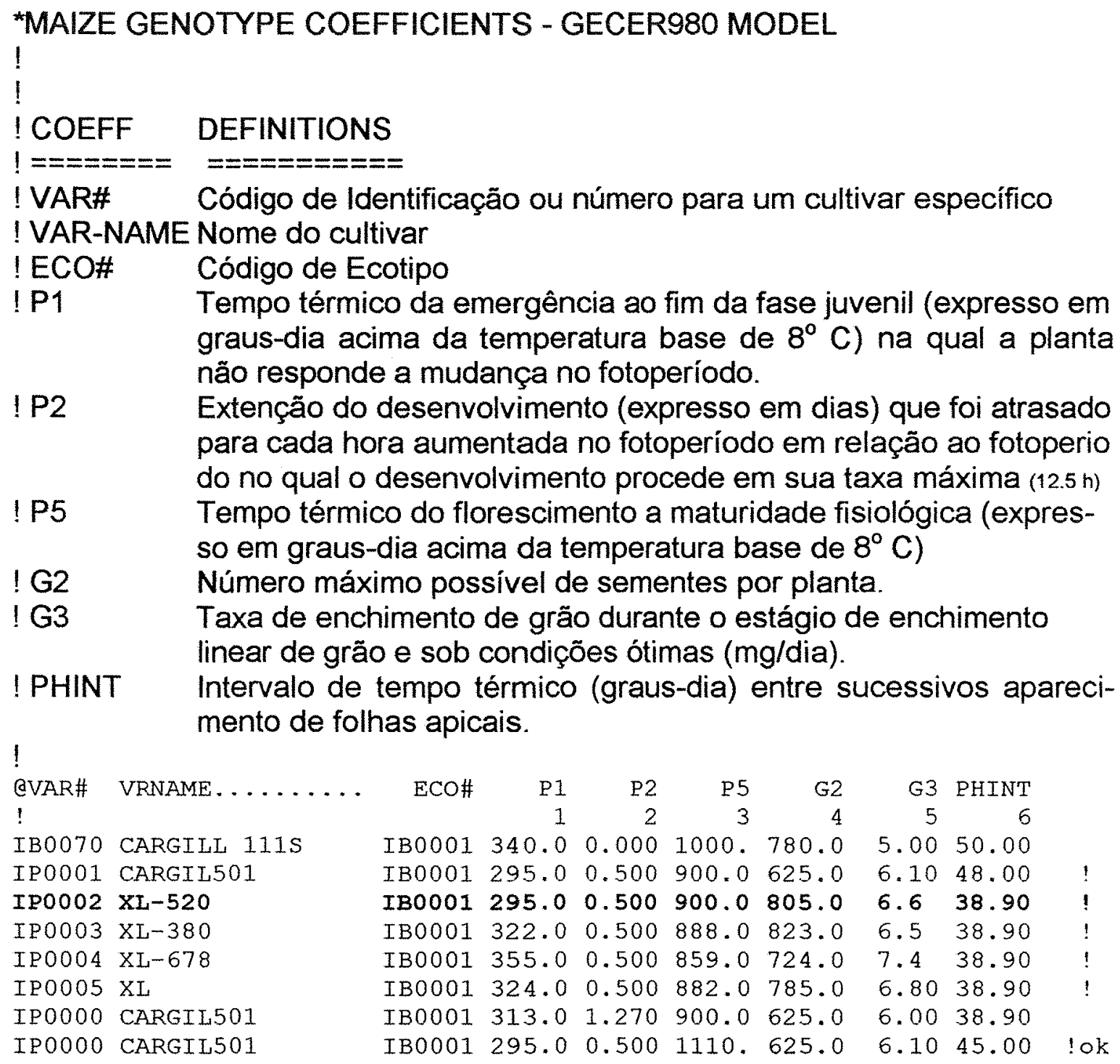




\section{ANEXO 4}

Tabela. Resultados médios do balanço de água no solo em Londrina, obtidos a partir das simulações com o modelo CERES-maize no periodo de 1976 a 1999

\begin{tabular}{|c|c|c|c|c|c|c|c|c|c|}
\hline $\begin{array}{l}\text { Semeadura } \\
\text { (decêndio) }\end{array}$ & $\begin{array}{c}\text { Tratamento } \\
(\%, A D)\end{array}$ & $\mathrm{N}$ aplic. & $\begin{array}{l}\text { Ir total } \\
\text { (mm) }\end{array}$ & $\begin{array}{c}\text { Taxa média } \\
\text { (mm/ap) }\end{array}$ & $\begin{array}{c}\text { Et } \\
(\mathrm{mm})\end{array}$ & $\begin{array}{l}\text { Prec } \\
(\mathrm{mm})\end{array}$ & $\begin{array}{c}\text { Drenagem } \\
(\mathrm{mm})\end{array}$ & $\begin{array}{c}\text { Escoam } \\
\text { (mm) }\end{array}$ & $\begin{array}{r}\text { Lixiv. N } \\
\left(\mathrm{kg}^{\prime} \mathrm{ha}^{-1}\right)\end{array}$ \\
\hline \multirow{5}{*}{$1^{\circ}$ dec. jan. } & Irrig. $10 \%$ AD & 3 & 102.5 & 39.1 & 595.4 & 685.0 & 199.1 & 121.8 & 7.3 \\
\hline & Irrig. $30 \% \mathrm{AD}$ & 5 & 147.1 & 32.1 & 501.5 & 685.0 & 225.5 & 124.2 & 8.5 \\
\hline & Irrig. $50 \%$ AD & 8 & 200.3 & 24.9 & 507.8 & 685.0 & 255.8 & 127.1 & 9.8 \\
\hline & Irrig. $70 \% \mathrm{AD}$ & 16 & 283.9 & 17.7 & 515.5 & 681.5 & 310.5 & 930.1 & 12.8 \\
\hline & Irrig. $90 \%$ AD & 40 & 421.9 & 10.5 & 536.8 & 681.1 & 411.0 & 134.4 & 19.0 \\
\hline \multirow{5}{*}{$2^{\circ}$ dec. jan. } & Imig. $10 \% \mathrm{AD}$ & 3 & 97.8 & 39.1 & 501.2 & 676.1 & 190.2 & 120.0 & 7.3 \\
\hline & imig. $30 \% \mathrm{AD}$ & 4 & 143.0 & 32.1 & 506.0 & 676.1 & 215.5 & 122.5 & 8.4 \\
\hline & Irrig. $50 \%$ AD & 8 & 189.5 & 24.8 & 510.5 & 676.1 & 250.3 & 125.4 & 10.0 \\
\hline & Irrig. $70 \% \mathrm{AD}$ & 16 & 282.8 & 17.6 & 529.5 & 676.0 & 312.6 & 129.3 & 13.0 \\
\hline & Irig $90 \%$ AD & 40 & 419.1 & 10.5 & 551.4 & 675.8 & 414.3 & 133.8 & 19.3 \\
\hline \multirow{5}{*}{$3^{\circ}$ dec. jan. } & Irrig. $10 \% \mathrm{AD}$ & 3 & 102.5 & 39.0 & 497.3 & 698.4 & 202.7 & 129.6 & 7.6 \\
\hline & Irrig. $30 \%$ AD & 5 & 147.6 & 31.9 & 501.8 & 698.4 & 228.7 & 131.9 & 8.5 \\
\hline & Irig $50 \%$ AD & 8 & 198.7 & 24.8 & 506.2 & 698.4 & 265.3 & 134.8 & 10.2 \\
\hline & Irrig. $70 \%$ AD & 16 & 281.1 & 17.6 & 522.3 & 695.8 & 322.6 & 138.3 & 13.3 \\
\hline & Irrig. $90 \% \mathrm{AD}$ & 40 & 418.6 & 10.5 & 541.1 & 697.7 & 430.6 & 143.1 & 19.9 \\
\hline \multirow{5}{*}{$1^{\circ} \mathrm{dec}$ fev. } & Irrig. $10 \% \mathrm{AD}$ & 3 & 97.6 & 39.1 & 486.6 & 669.5 & 189.0 & 121.3 & 6.8 \\
\hline & Irrig. $30 \%$ AD & 5 & 147.5 & 31.9 & 491.8 & 669.5 & 222.2 & 123.8 & 8.1 \\
\hline & Irtig. $50 \%$ AD & 8 & 197.1 & 24.8 & 497.3 & 669.5 & 256.0 & 126.5 & 9.4 \\
\hline & Irrig $70 \% \mathrm{AD}$ & 16 & 283.1 & 17.5 & 515.6 & 669.5 & 316.6 & 130.5 & 12.4 \\
\hline & Irrig. $90 \% \mathrm{AD}$ & 41 & 425.8 & 10.4 & 537.2 & 669.5 & 424.5 & 134.5 & 18.5 \\
\hline \multirow{5}{*}{$2^{\circ} \mathrm{dec}$ fev. } & Irrig. $10 \% \mathrm{AD}$ & 3 & 100.6 & 39.0 & 479.0 & 6327 & 180.7 & 116.1 & 6.6 \\
\hline & Irrig. $30 \% \mathrm{AD}$ & 5 & 153.9 & 31.8 & 483.3 & 632.7 & 212.5 & 118.8 & 7.8 \\
\hline & Irrig. $50 \%$ AD & 9 & 210.3 & 24.7 & 490.1 & 632.7 & 249.5 & 121.5 & 9.2 \\
\hline & Irrig. $70 \% \mathrm{AD}$ & 16 & 288.0 & 17.5 & 510.0 & 632.7 & 298.1 & 125.0 & 11.5 \\
\hline & Irrig. $90 \% \mathrm{AD}$ & 41 & 426.1 & 10.4 & 531.1 & 6327 & 401.3 & 129.3 & 17.2 \\
\hline \multirow{5}{*}{$3^{\circ}$ dec. fev. } & Irrig. $10 \% \mathrm{AD}$ & 3 & 115.1 & 38.9 & 471.0 & 589.2 & 107.6 & 173.8 & 6.5 \\
\hline & Irrig. $30 \% \mathrm{AD}$ & 5 & 157.4 & 31.7 & 476.4 & 589.2 & 109.8 & 197.8 & 7.3 \\
\hline & Irrig. $50 \% \mathrm{AD}$ & 9 & 215.6 & 24.8 & 482.2 & 589.2 & 112.1 & 237.6 & 8.7 \\
\hline & Irrig. $70 \%$ AD & 17 & 302.8 & 17.5 & 505.8 & 589.2 & 116.1 & 286.0 & 11.0 \\
\hline & Irrig. $90 \% \mathrm{AD}$ & 42 & 437.3 & 10.3 & 527.8 & 589.2 & 119.5 & 383.2 & 15.9 \\
\hline \multirow{5}{*}{$1^{\circ}$ dec. mar. } & Irrig. $10 \% \mathrm{AD}$ & 3 & 128.3 & 39.0 & 467.6 & 568.6 & 173.2 & 103.0 & 6.0 \\
\hline & Irrig. $30 \% \mathrm{AD}$ & 5 & 169.2 & 31.7 & 474.0 & 568.6 & 193.5 & 104.0 & 6.8 \\
\hline & Irrig. $50 \% \mathrm{AD}$ & 9 & 226.2 & 24.7 & 481.0 & 568.6 & 227.0 & 107.2 & 8.1 \\
\hline & Irrig. $70 \% \mathrm{AD}$ & 18 & 313.3 & 17.4 & 507.5 & 568.9 & 275.9 & 111.5 & 10.2 \\
\hline & Irrig. $90 \% \mathrm{AD}$ & 43 & 440.8 & 10.3 & 525.7 & 568.6 & 371.5 & 114.8 & 15.3 \\
\hline \multirow{5}{*}{$2^{\circ}$ dec. mar. } & Irrig. $10 \% \mathrm{AD}$ & 3 & 131.2 & 38.9 & 456.5 & 538.5 & 163.0 & 95.1 & 5.6 \\
\hline & Irrig. $30 \% \mathrm{AD}$ & 6 & 175.2 & 31.9 & 461.8 & 538.5 & 188.3 & 97.1 & 6.5 \\
\hline & Irrig. $50 \% \mathrm{AD}$ & 9 & 233.9 & 24.7 & 470.9 & 538.5 & 222.7 & 99.8 & 7.7 \\
\hline & Irrig. $70 \% \mathrm{AD}$ & 18 & 313.7 & 17.3 & 496.2 & 538.5 & 268.1 & 102.9 & 10.1 \\
\hline & Irrig. $90 \% \mathrm{AD}$ & 42 & 438.2 & 10.4 & 517.1 & 538.5 & 356.3 & 106.8 & 14.8 \\
\hline \multirow{5}{*}{$3^{\circ}$ dec mar. } & Irrig. $10 \% \mathrm{AD}$ & 3 & 128.1 & 38.9 & 448.2 & 527.3 & 161.3 & 91.7 & 5.4 \\
\hline & Irrig. $30 \% \mathrm{AD}$ & 6 & 179.0 & 31.8 & 453.7 & 527.3 & 190.3 & 93.5 & 6.6 \\
\hline & Irrig. $50 \% \mathrm{AD}$ & 9 & 228.9 & 24.7 & 462.8 & 527.3 & 221.6 & 96.9 & 7.8 \\
\hline & Irrig. $70 \% \mathrm{AD}$ & 18 & 315.1 & 17.3 & 491.0 & 527.3 & 267.8 & 99.8 & 10.1 \\
\hline & Irrig. $90 \%$ AD & 43 & 443.7 & 10.4 & 510.5 & 527.3 & 362.7 & 103.0 & 15.3 \\
\hline \multirow{5}{*}{$1^{\circ}$ dec. abr. } & Irrig. $10 \% \mathrm{AD}$ & 3 & 131.4 & 38.9 & 448.9 & 517.0 & 157.1 & 89.7 & 5.8 \\
\hline & Irrig. $30 \% \mathrm{AD}$ & 6 & 183.4 & 31.9 & 454.6 & 517.0 & 186.3 & 91.8 & 6.9 \\
\hline & Irrig. $50 \%$ AD & 9 & 230.6 & 24.7 & 465.3 & 517.0 & 211.7 & 94.9 & 8.2 \\
\hline & Irrig. $70 \% \mathrm{AD}$ & 19 & 321.5 & 17.3 & 496.2 & 517.0 & 257.2 & 98.2 & 10.5 \\
\hline & Irrig. $90 \%$ AD & 45 & 459.8 & 10.3 & 516.3 & 517.0 & 363.9 & 101.7 & 16.5 \\
\hline \multirow{5}{*}{$2^{\circ}$ dec. abr. } & Irrig. $10 \% \mathrm{AD}$ & 3 & 134.9 & 39.0 & 448.8 & 524.1 & 166.2 & 89.4 & 6.6 \\
\hline & irrig. $30 \%$ AD & 6 & 186.6 & 31.8 & 454.5 & 524.1 & 194.3 & 92.0 & 7.8 \\
\hline & Irrig. $50 \% \mathrm{AD}$ & 10 & 235.2 & 24.6 & 465.7 & 524.1 & 219.7 & 94.3 & 9.2 \\
\hline & Irrig. $70 \%$ AD & 19 & 329.8 & 17.3 & 497.5 & 524.1 & 272.7 & 96.7 & 12.0 \\
\hline & Irrig. $90 \% \mathrm{AD}$ & 46 & 468.5 & 10.2 & 517.5 & 524.1 & 378.4 & 100.9 & 18.6 \\
\hline
\end{tabular}


cont.

\begin{tabular}{|c|c|c|c|c|c|c|c|c|c|}
\hline \multirow{5}{*}{$3^{\circ}$ dec abr. } & Irrig. $10 \% \mathrm{AD}$ & 4 & 146.2 & 39.0 & 470.7 & 529.1 & 162.8 & 86.2 & 6.7 \\
\hline & Inrig. $30 \% \mathrm{AD}$ & 6 & 186.3 & 31.9 & 476.4 & 529.1 & 184.3 & 88.0 & 7.7 \\
\hline & Irrig. $50 \%$ AD & 10 & 244.8 & 24.8 & 486.1 & 529.1 & 217.4 & 90.8 & 9.1 \\
\hline & Irrig. $70 \%$ AD & 19 & 334.9 & 17.3 & 515.6 & 529.1 & 269.1 & 93.4 & 12.1 \\
\hline & Imig. $90 \%$ AD & 47 & 475.9 & 10.1 & 532.5 & 529.1 & 380.0 & 97.7 & 19.1 \\
\hline \multirow{5}{*}{$1^{\circ} \mathrm{dec}$ mai. } & Inrig. $10 \% \mathrm{AD}$ & 4 & 146.5 & 39.1 & 479.3 & 535.0 & 157.8 & 86.4 & 6.7 \\
\hline & Irrig. $30 \%$ AD & 6 & 187.2 & 31.9 & 486.3 & 535.0 & 177.6 & 88.1 & 7.6 \\
\hline & Irrig. 50\% AD & 10 & 250.3 & 24.7 & 497.2 & 535.0 & 216.5 & 90.9 & 9.6 \\
\hline & Irrig. $70 \%$ AD & 20 & 348.2 & 17.4 & 527.9 & 535.0 & 272.9 & 94.5 & 13.1 \\
\hline & Irrig. $90 \% \mathrm{AD}$ & 48 & 483.2 & 10.1 & 544.4 & 535.0 & 378.8 & 98.7 & 20.2 \\
\hline \multirow{5}{*}{$2^{\circ}$ dec. mai. } & Imrig. $10 \% \mathrm{AD}$ & 4.0 & 154.2 & 39.0 & 480.6 & 519.2 & 148.8 & 83.3 & 6.4 \\
\hline & Irrig. $30 \% \mathrm{AD}$ & 5.9 & 187.4 & 31.9 & 489.5 & 519.2 & 164.7 & 84.1 & 7.1 \\
\hline & Irrig. 50\% AD & 10.3 & 253.8 & 24.7 & 500.8 & 519.2 & 205.4 & 87.0 & 9.1 \\
\hline & Irrig. $70 \%$ AD & 20.2 & 350.8 & 17.4 & 531.8 & 519.2 & 261.6 & 90.2 & 12.5 \\
\hline & Imrig. $90 \%$ AD & 48.0 & 486.5 & 10.1 & 547.6 & 518.2 & 368.7 & 94.5 & 19.8 \\
\hline \multirow{5}{*}{$3^{\circ}$ dec mai. } & Imig. $10 \% \mathrm{AD}$ & 4 & 154.3 & 39.0 & 499.8 & 516.5 & 140.3 & 81.9 & 5.9 \\
\hline & Imig. $30 \%$ AD & 6 & 205.0 & 31.9 & 510.0 & 516.5 & 163.2 & 84.5 & 6.8 \\
\hline & Irrig. $50 \%$ AD & 11 & 269.3 & 24.9 & 523.0 & 516.5 & 200.6 & 87.5 & 8.6 \\
\hline & Irrig. $70 \% \mathrm{AD}$ & 21 & 367.2 & 17.5 & 552.9 & 516.5 & 253.1 & 90.7 & 11.8 \\
\hline & Irrig. $90 \% \mathrm{AD}$ & 49 & 499.0 & 10.2 & 567.1 & 516.5 & 359.5 & 94.4 & 18.6 \\
\hline
\end{tabular}

